Historic, Archive Document

Do not assume content reflects current scientific knowledge, policies, or practices. 



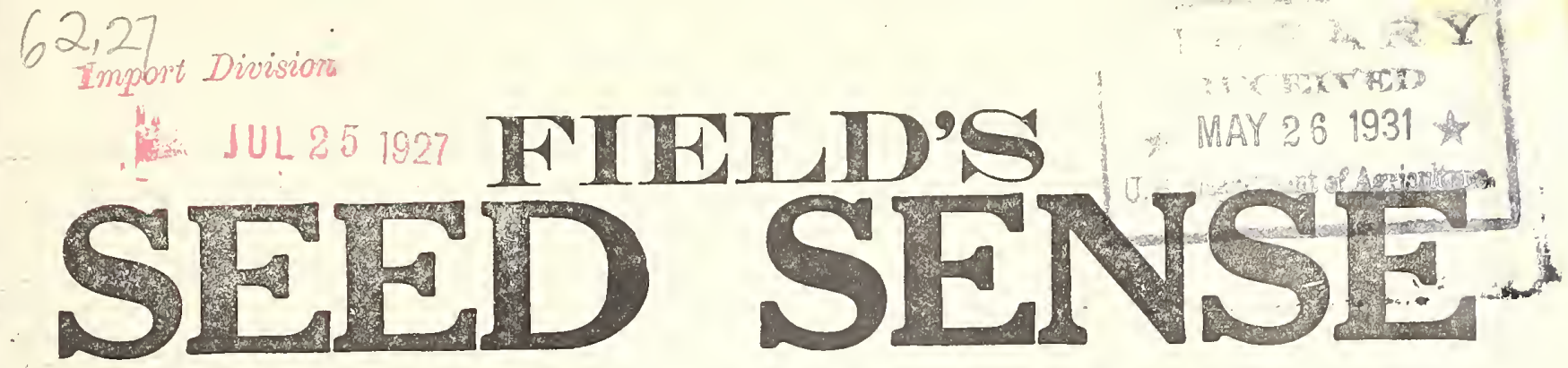

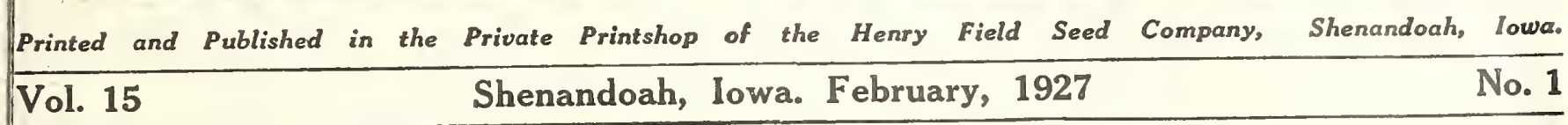

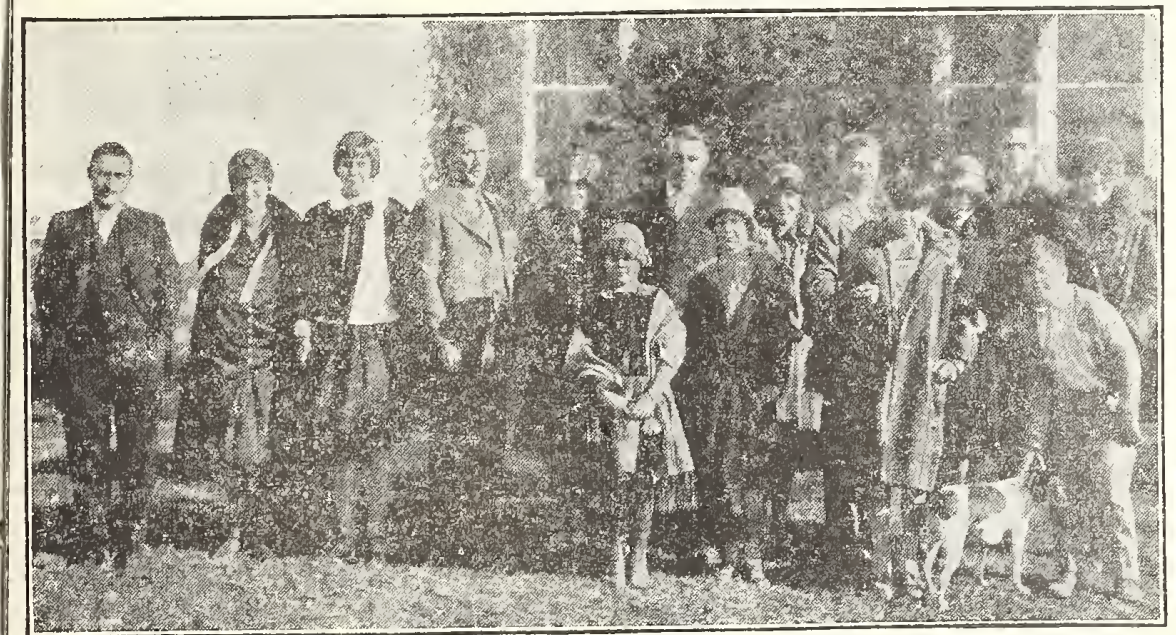

\section{Here We Are Again}

Here is the very latest picture of the Field family, taken at Christmas time, 1926. Yes, you will notice some new faces there, as we have had two weddings in the family since a year ago.

You have probably seen the picture of Frank's wife and of Jessie's husband in the catalog, but this picture shows you also Hope's husband. Also you will note that the smaller children are growing up fast.

In the back row, here's who they all are: Frank, Frank's wife Jennie, Mary, H. F., Hope, Hope's husband Leo Pawek, Jean, Philip's friend, Philip, Josephine, Jessie's husband John Desch, Jessie.

In the front row are: Lettie, Georgia, Ruth and John Henry, and down in front is the children's pup, Skeesix.

I suppose it is news to you about Hope's recent marriage, and this is the first time you have had a chance to see a picture of her husband. She was married last August, but they did not announce the wedding until Christmas time this winter His name is Leo Pawek and he is Athletic Director of the Junior College at Creston, Ia.

Philip, Josephine and Jean are going to college at Ames, now, and Jessie and her husband, John Desch, are working at the seedhouse. Frank and his wire both work at the seedhouse, too. Frank is Superintendent of the Nursery Department. Mary will graduate from High School this year, and the four youngest children are all in school. Ruth is in High School and the others in the grades.

The only one missing from the picture is Faith, who is now living in California and declares she is never coming back to Iowa.

We are all well and busy as usual, and you will see by the picture that the children are all still growing. In fact, it will not be very long until I will have not little folks around me at all, as they will be grown up. Lettie, the baby, is now 8 years old and very much of a young lady, and resents very much being called the baby of the fanily. John Henry is almost as tall as his older sisters, if he had straightened up instead of stooping over holding the dog.

I have five grandchildren, also, but none of them are in the picture. Frank has two boys and a giri and Faith has two boys, who are with her out in California.-H.F.

\section{Our Broadcasting Station KF N F - 461 Meters}

If you possibly can, you should listen in to our broadcasting station. Most of the people within 500 miles are already listening, but this Seed Sense may go to some who are not listening regularly.

You will find us on 461, which is just below Davenport and Omaha, and just above Minneapolis and Cincinnati.

We have thousands of visitors and always glad to have more. $-H$. F.

\section{A Busy Year at the Seedhouse}

We are having a wonderful year of business at the seedhouse, - everybody busy and everybody happy. We are having by far the best year's business we have ever had and of course, everybody is enthusiastic about it and working hard. er than ever.

Besides the regular seed and nursery and plant business, which is running heavier than ever, we are having splendid business in our newer merchandise lines.

We put on these merchandise lines to take care of the slack season in the summer and to keep our help busy rather than lay them off, but instead of slacking down in the winter, these new lines run heavier than ever right on through the winter, so you can see it is keeping us mighty busy.

We are selling a carload of automobile tires a week, and that's quite a lot of tires, if you ask me.

On radio sets, we are selling an average of about 30 a day.

Then there is the dress goods, the shoes, the overalls and the dried fruit, and the paint and the harness, all doing a tremendous business.

It looks like these new merchandise lines liad come to stay, and that other lines will gradually join them, for every one has been a tremendous success.

The secret of it all is that we are giving absolutely first quality merchandise at a reasonable profit.

It is not a question of price with us, but first a question of absolute quality and then after we get the quality we want, we try and figure the profit just as close as we can, handling a big volume on a quick turn over, and in that way, we get the goods to you at a price that will save you money, and that's what you want.

There is no use working hard and sav. ing your money unless you can make every dellar of it buy a dollar's worth of goods.

We have separate circulars or catalogs on a number of these items and others are included in the general catalog.

The shoes and tires are described fully in the regular catalog, and in this seed Sense. On some of the things, you will have to write for special prices.

Whatever you buy from us, whether it is seeds, nursery stock, merchandise of any kind, you may rest assured that it has back of it, our usual guarantee of your money's worth or your money back, and that is the big argument in the long run. that is the big argument in the long run. 


\section{lowa Acc}

\section{Accredited Baby Chicks of Quality}

this season to 85000 ests at one setting and promptly.

Place your orders early so we can make shipment right at the time you want your chicks. Hatch comes oft every Monday from February 1 st to June 15th.

These prices are deliveted to your door, parcel post prepaid, 100 percent live delivery guaranteed.

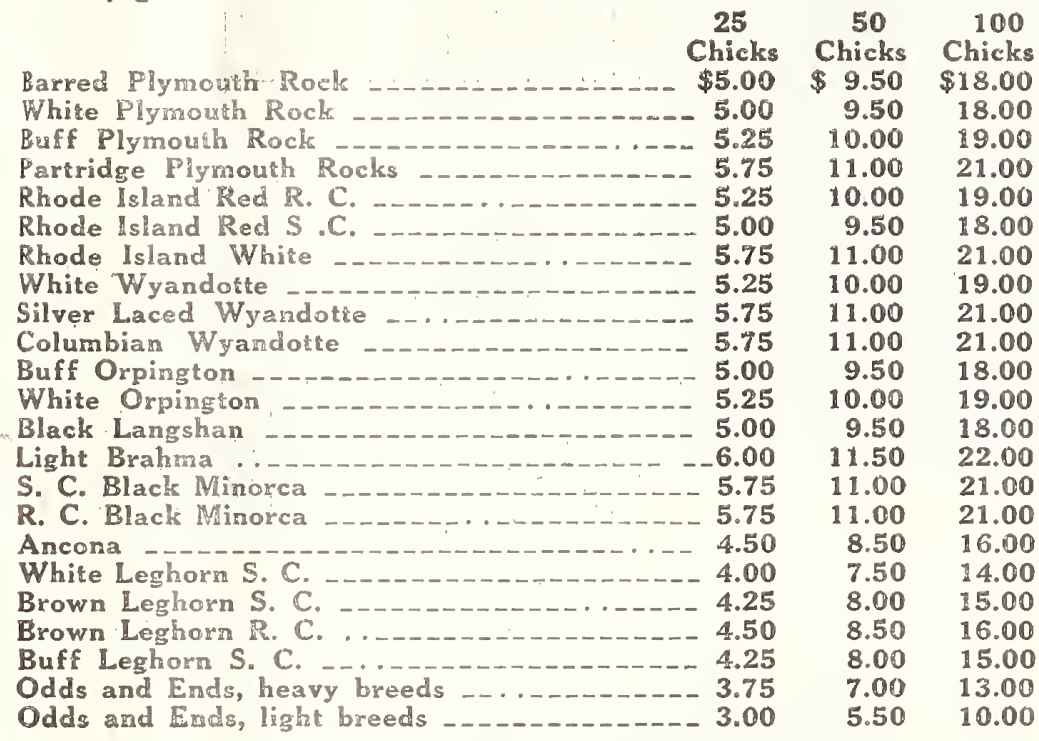

Big healthy, sturdy fellows, delivered to your door, parcel post prepaid, 100 percent inspected by an inspector authorized by lowa Accredifed Hatchery Association. They are liatched, right. They are sold right

e have increased our hatching capacity

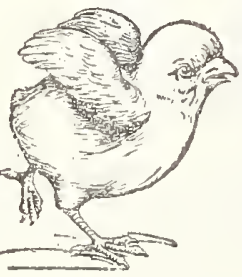
stock is of pure blood lines. Every bird

orders (3) e 500 Chicks $\$ 85.00$ 85.00 90.00

100.00

90.00

85.00

100.00

$\mathbf{9 0 . 0 0}$

100.00

100.00

85.00

90.00
85.00

105.00

100.00

100.00

75.00

65.00

70.00

75.00

70.00

65.00

50.00

\section{Guarantee On Baby Chicks}

We guarantee 100 percent live delivery, and will deliver to the postoffice chicks that are strong and healthy, and able to travel to any state in the country.

If you do not receive 100 percent live delivery, get a signed statement from your postmaster or mail carrier for the number dead or short and mail to us and we will replace them or refund your money.

Our chicks are hatched right and shipped right, or we could not make this kind of a guarantee. No other claims or adjustments will be allowed on dead or short chicks.

\section{Better Overalls and Other Work Clothing}

We have been thinking for a long time of going into the work clothing business, but not until we could design a better quality than anything on the market.

This we have now done, and we sell them guaranteed to be better than any you ever bought, of any make or at any price.

We are handling the entire line of men's bib overalls, either high back or suspender back, men's jackets to match, boys' overalls and jackets, and men's chambray work shirts.

These are all sold with the absolute guarantee of your money's worth or your money back.

At any time, within six months, if you feel that you haven't got your money's worth and more too, on this clothing, you can return it and have your money back. If it wears out or gives away in any particular, we want to know it, so that we can correct the fault, but I don't see where it can possibly give away in any particular.

Everything will be sold posipaid, delivered to your mail box.

The garments are all made of the heaviest and best material, reinforced in every possible way and with the very latest ideas in pockets and other attractive features.

Write fur circular giving illustration and complete details.

\section{Prices on Work Clothing}

Here are condensed prices.

Men's Bib Overalls, either high back or suspender back, 3 for $\$ 5.00$ postpaid. Men's Jackets to match, same price.

(You can order two pairs overalls and one jacket to make the $\$ 5.00$ )

Oversize (44 to 50 waist) $10 \%$ higher. Big Boys' Overalls and Jackets (Ages $15 \cdot 16-17-18) 3$ for $\$ 3.50$.

Medium Boys' Overalls and Jackets (Ages 9 to 14 inclusive) 3 for $\$ 3.00$.

Small Boys' Overalls and Jackets (Ages 3 to 8 inclusive) 3 for $\$ 2.50$.

Men's Chambray Work Shirts, either blue or gray, (Specify if Slim, Stout or Regular) 3 for $\$ 2.50$.

Big Boys' Shirts, same as above, Sizes $12 \frac{1}{2}$ to 14 neck, 3 for $\$ 2.00$.

Small Boys' Shirts, neck sizes 10 to 12, 3 for $\$ 2.00$.

Please note that these prices are all postpaid, and you can make up the assortment any way you please. For instance, you can order two pair of overalls and $a$ jacket at the price of three, or you can order two blue shirts and one gray, or you can have all one color,-just as you please. Ask for circular, which will explain this fully.

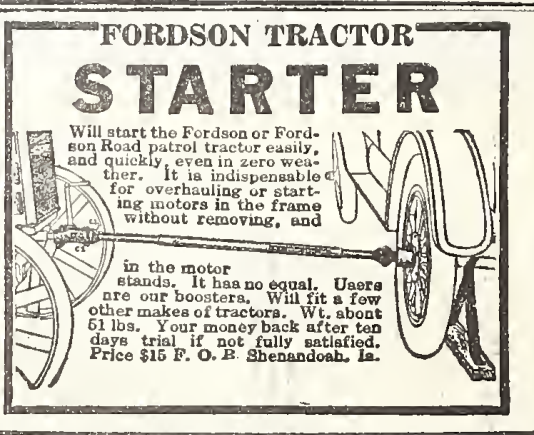

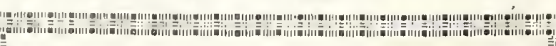

\section{Our New Wall}

\section{Paper Dept.}

No catalog, but a brand new idea in selling wall paper.

Tell our experts what style, color and type of wall paper you desire.-They will please you, if they don't, you may send the paper back. The uswal Field Guarantee.

Listen in on $K F N F$ or drop us a card for order blank.

Investigate our way before you buy.-You will save money and be completely satisfied. 


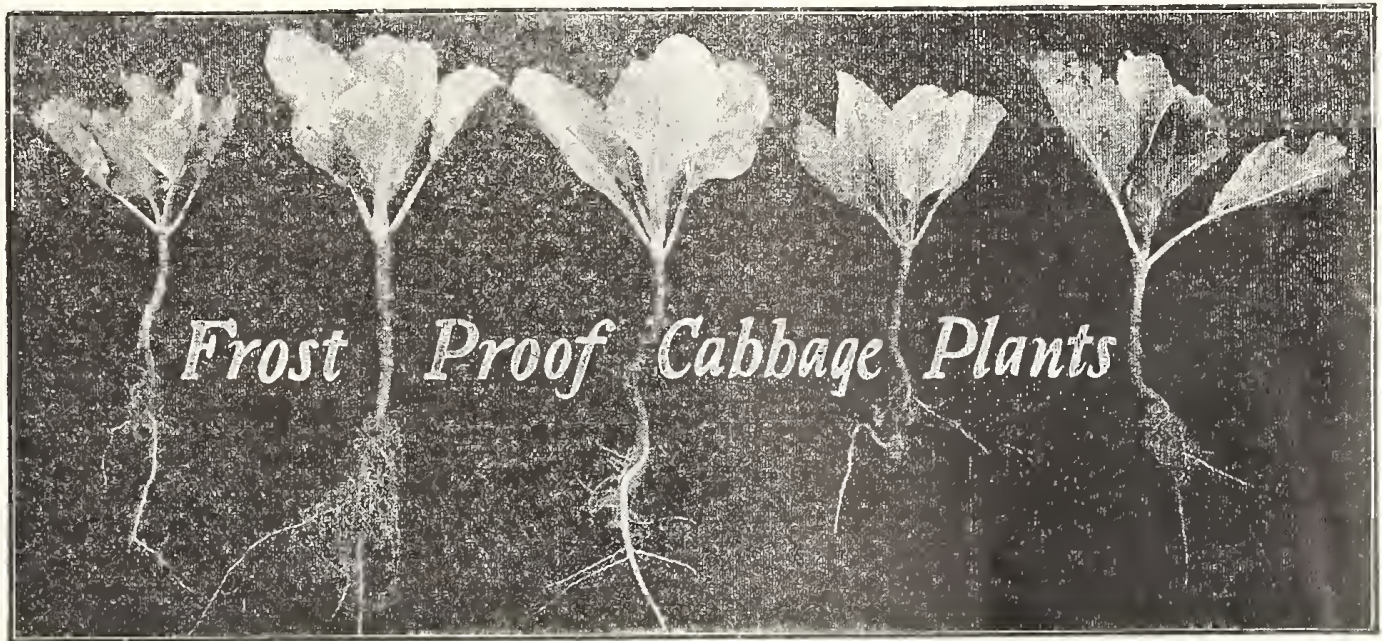

30 c to 50c PER 100 IN QUANTITY

These plants are grown in the far South. The seed is planted jng days will bring them out and they will outgrow and head in the Fall and they make quite a growth before Winter sets up earlier than soft indoor plants.

in, then the cold weather and frosts hold them dormant. When Spring comes they are tough and hardy and will stand our early Spring frosts and unfavorable weather without a setback. During their winter, they have just weather as we do in early Spring. The reason they can be sold cheaper is that they are grown cheaper. They are growll as a field crop down Soutl,
acres and acres of them. No hotbed, cold-frame, or heating or acres and acres of them. No hoted, to them.

No order for less than 100 plants filled. If this is more than you need, do your neighbor a favor by clubbing with him. This is a chance to buy a hundred hardy, field-grown plants at about the price usually charged for a couple of dozen ordinary plants.

The varieties we can furnish are: 995 Wakefield, 994 Flat Dutch, and 993 Allhead. Prices: 50c per 100; $\$ 1.00$ per $200 ; \$ 2.00$ per 500 , postpaid; or $\$ 3.00$ per 1000 , by exThese Frost Proof plants can take a lot of punishment and press, not prepaid. We can also furnish 992 Norseman at 65 c
perser come up smiling for they are used to it. They have stood out per 100 , more, at $\$ 3.75$ per 1000 , not prepaid. Ready any in the field all Winter long without even the shelter of a cold-

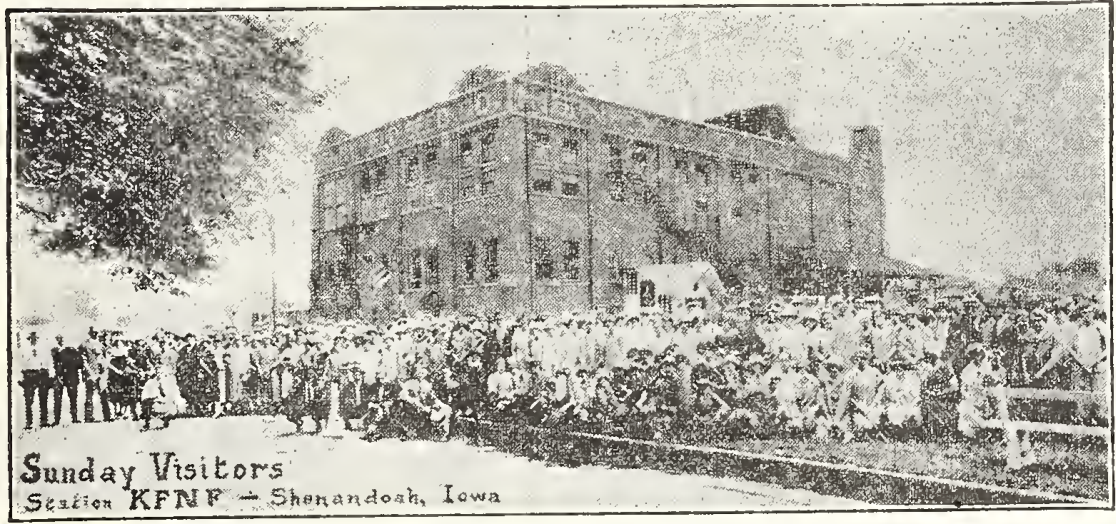

This Will Give You An Idea Of The Number Of Folks That

\section{Come To See Us Every Day}

This picture was taken one Sunday afternoon last summer and will give you some faint idea of the crowds of people who come to see us every day during the summer and to a lesser extent during the winter also. This picture only shows a few hundred people, but on some Sundays last summer when the weather and roads were both good, we entertained as high as two and three thousand people. Some of them live a half-hour or hour's journey from Shenandoah but many of them drive hundreds of miles to come to see us.

The way we keep track of the number of people who visit us each day, is by counting the badges that the girls pin on at the front door. A girl stands just inside the door and as each visitor comes into the building, she pins a badge on his coat, which says, "A visitor to K. F. N. F." She has these all counted out before hand, one hundred to an envelope and at the end of the day she counts her empty envelopes will

\section{Chinese Cabbage}

It is a little like cabbage; something like a very large head of Cos lettuce; has a faint mustard flavor and some folks call it Celery Cabbage. The picture above shows you just what it looks like but you will have to sample it to know just what

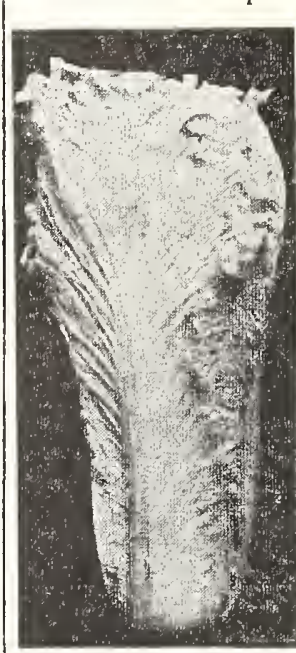
tastes like. It can be used in any way that cabbage or let. tuce can.

Don't plant it in the spring of the year, here in the middle wiest, or you may be disappointed. Plant it the same time you do late turnips, "twentyfifth of July, wet or dry." Rows should be eighteen inches or more apart. Thin out later to eighteen or twienty-four inches in the row. When the center leaves turn a creamy yellow, draw the outer leaves over

Chinese Cabbage and tie them so the head will bleach out, which it will do in a week or ten days. It will be crisp and ender and of a delicate flavor that you lll all like. Price per packet 5c; ounce $5 \mathrm{c}$. 


\section{No.996 Canary Island Bermudas}

We have learned, during the last three or four years, that these onions can be Proof cabbage plants, and that is just as grown in the North. They have been grown in Texas for a good many years and early as you can make garden. A frost are marketed in the North during April, May and June. They have always sold at or light freeze will not hurt them after high prices on account of the quality, and because the supply was limited and the they are out in the field. The plants are demand was good.

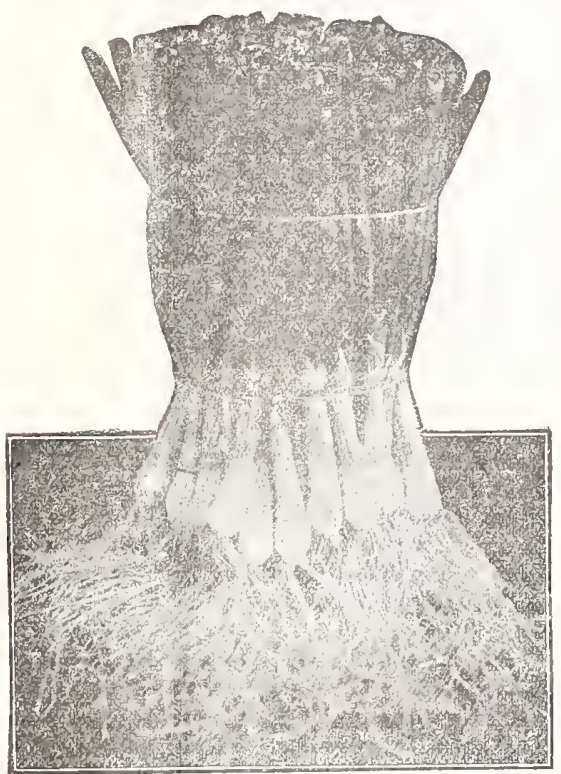

Well Rooted Plants

\section{A Very Mild Sweet Onion}

This is an onion that you can bite into with perfect confidence that it will not set fire to your interior anatomy. You will enjoy its mild sweet flavor whether eaten raw or cooked. There is nothing finer than these Bermuda onions sliced
thin and used for sandwiches. This mild flavor is the result of selecting for a great many years only the mild onions for seed. They are not as good keepers as some of our native varieties but make up in quality.

\section{Use These Plants in Place of Onion Sets}

You can use these Bermuda plants to grow your bunch onions for early spring use. Of course, they will make a bulb later on, and this makes them worth much more than the onion sets, which will not always form a bulb. The young green onions or Bunch onions have the same mild flavor that the large onions do. They mature fully as early as onions from sets.

\section{A Cood Marketable Onion}

These Bermuda onions come in before the native varieties from seed do and after the Texas Bermudas are of $\mathrm{f}$ the market. Therefore, they should find a good market here in the North. They can be grown as a sideline, or you can grow a large crop, providing you have a suitable market nearby where you can dispose of them. They are not keepers so should be sold during the summer or fall.

\section{Fresh Plants}

We are handling our plants differently from last season. We learned a lot from last year and are going to profit by it. Our plants will reach Shenandoah from Texas just as fresh as the day they left. They will be unloaded and mailed out at once. We are fixed to unload and mail out as many as one car a day. We will mail the plants to you in strong, ventilated boxes instead of rolling them in a wrapper as we did last year, Crates used have two compartments and well ventilated. There is no reason why they should not reach you, if you are three

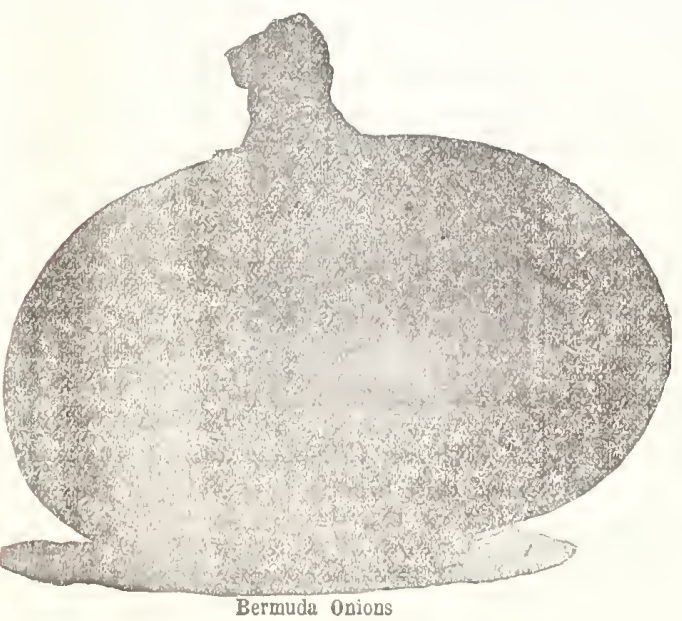
or four days from Shenandoah, just as fresh as they can be.

\section{How to Grow Them} grown from seed here in the fore the bulb starts to form. Bermudas are North. They must mature be- grown on contract for us, and the seed fore our hot dry summers, and planted at the proper time to produce they do not have time to do this plants ready to ship when we want them, if started from seed. Setting neither too old or too young. We have the plants out enables your crop found that we cannot hope to get good to reach full growth before our plants buying from Tom, Dick and Harry, het weather. Down in Texas nobody knows when planted or when dug, where they have been grown for or how long they have been in storage, so vears, they transplant to the we placed an order with two growers in field. I suppose they figure set- Texas whom we know personally and ting the plants is as cheap as who have demonstrated their ability to thinning seed onions, and I furnish gocd rlants. Both have had years would judge that thev are right of experience in growing this crop. We in this. They should be set out inke their entire cr, a id the plants very early; is early as Frost are grown especially for us. 


\section{Protect Crop Fiom riost}

Insure Against Th i.eza d "Hotkaps" Stimulate Crowth, So You Can Be Earier To Market For Betler Prices, Individual Hothouses for Each and Every Plant

Be the first to market this season. Get a premium for your crops because they are delivered first. Hundreds did. it last year. Now the opportunity is i yours.

Use "Hotkaps", individual hothouses" that completely cover each plant, protecting them from frost, and stimulating a rapid, healthy growth. "Hotkaps", also afford protection from heavy rains, for they are waterproof. Plants are shielded from other elements too, in this wav. Yet they get ample moisture and ventilation.

Easy to use. One man can put 3,000 in place per day. The cost is small. The most economical, and the most certain insurance for plants known, against frost, rain, exciessive heat, and wind.

Growers who prepare land and plant oseed early in the spring run the dangerous risk of late frosts. Frequently it is too late, then. to plant another crop. Time and effort are wasted; money is lost.

"Hotkaps" insure against this condition. They not only protect against frost, but shield young plants from wind and insects and eliminate the possibility of the plant being damaged in a heavy rain. "Hotkaps" are waterproof. They guard against too much moisture, which frequently causes a delay and weakened growth.

"Hotkaps" are made of a specially prepared wax paper and are cone-like in shape, measuring about 11 inches in diameter at the base and coming to a point at the top. When placed over the plants and held firmly in place by the soil around it, "Hotkaps" become individual miniature hot-houses. They are reinforced by a strip of heavily waxed paper to guard against outside pressure. Rain will not destroy them nor will it injure or lessen their effectiveness in any way.

Only the slightest pressure is required to force the "Hotkap" down, as from $1 / 4$ to $1 / 2$ inch only should be below the surface. Operator should carefully see that the soil is placed on the protruding edge to keep the "Hotkap" rigidly in place. The Setter thus enables the grower to place the "Hotkap" quickly and efficiently. It is well made and can be kept and used indefinitely.

Price, boxed for shipment $\$ 10.00$ per 1000 , or $\$ 2.00$ per 100 , not prepaid. Less than 1000 at the hundred rate as they come from the factory boxed ready for shipment. Hotkap Setter \$2.50, not prepaid.

\section{The Earliest Varieties}

Many customers who live in the far North and others who want an especially early garden, often ask us to name the earliest varieties we list in our catalog. The following are probably the earliest. The list is not intended to be complete, but a selection of the best early:

BEANS-

121 - Early Wonder Wax

109-Field's First Early

TABLE BEETS607-Early Wonder

MANGEL BEETS-

All about the same season

CABBAGE-

527 -Norseman

522 Early Jersey Wakefield

CARROTS-

633 - Early Orange

629-Oxheart

CAULIFLOWER-

All early

CELERY

663-White Plume

662-Golden Self Bleaching

CUCUMBER -

354-Early Cluster.

LETTUCE-

509-Black Seeded Simpson

506-May King

MUSKMELONS-

333-Hale's Best

334-Greeley Wonder

ONIONS-

306-Mountain Danvers

316-Mountain Red Globe

PARSNIPS-

Same Season

PEAS-

146-Alaska

147-Fillbasket

148-Improved Extra Early

PEAS WRINKLED-

149-American Wonder

152-Little Marvel

PEPPERS (Sweet) -

639-Early Sweet Pimento

POPCORN-

195-Japanese Hulless

PUMPKINS-

Not much difference

SQUASH-

Not much difference

RADISHES

446-Saxa

448-Icicle

SWEET CORN-

174-Early Sunshine

183-Early Mayflower

177-Golden Bantam

TOMATOES-

402-Field's Early June

401-Red Head

TURNIPS-

803-Extra Early Milan

WATERMELON-

717 -Princess

713 -Early Fordhook 


\section{Seli Cut Flowers}

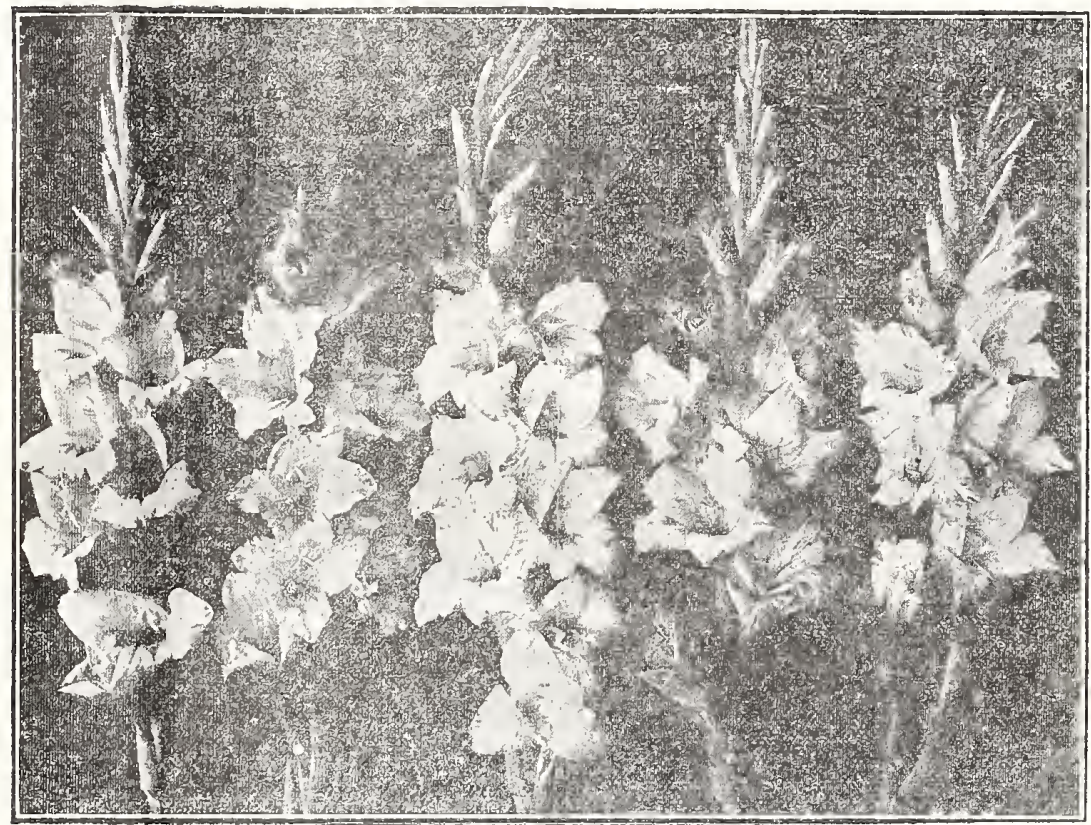

If you are located near a mariket for flowers, or live on a main traveled road, especially a road where there is considerable tourist travel, you should find good sale for cut flowers. There are no finer flowers for this purpose than Gladiolus, and the following list are among the best.

Glads bloom during vacation time when the children are at home from school and when the tourists are traveling. So it seems things combine just right for a roadside market. By a Roadside Market I mean a little stand erected at the side of the main traveled road where you can display whatever you wish to sell and draw your trade from people traveling by. Your boy or girl can tend a stand by the roadside just as well as a grown person.

We would Suggest the following list as especially valuable for cut flowers. They are all the large flowered kinds. Would suggest you buy some of the bulblets of these varieties where we have them for sale and grow your own bulbs for next year.

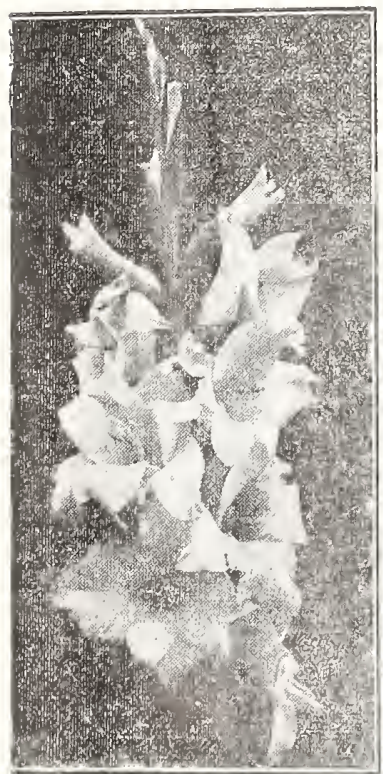

1420-America. Soft rose-pink, throat marked with Tyrian rose. This is an old favorite. $35 \psi^{6}$ per dozen; $\$ 2.85$ per 100 . Bulblets, $50 \%$ per 100.

1451--Anna Eberius. A dark velvety purple, throat a deeper shade. A very striking color and well liked by all who have seen it. Prolific and a strong grower. 35 per dozen; $\$ 2.85$ per 100 . Bulblets, 50 per 100.

1461-Crackerjack. A velvety dark red with yellowish throat. A popular variety; very prolific. 35 per dozen; $\$ 2.85$ per 100 . Bulblets, 50 per 100.

1422 - Evelyn Kirtland. Beautiful pink with scarlet blotch in throat. 35 per dozen; $\$ 2.85$ per 100 . Bulblets, 50 \& per 100 .

1410-Gretchen Zang. Pink blending into scarlet on lower petals. A big, strong spike. $35 \%$ per dozen; \$2.85 per 100 . Bulblets, $50 \mathrm{C}$ per 100 .

1423-Halley. Delicate Salmon-pink. Large and very early. 35 per dozen; $\$ 2.85$ per 100 . Bulblets, 50 per 100.

1423-Hereda. Deep lilac-mauve, gîstening and clear. A very rare and attractive color, 35 per dozen; $\$ 2.85$ per 100 . Bulblets, 50 \& per 100 .

1425- Le Marechal Foch. Bright rose-pink. Large wide open flowers. Probabiy the most popular new

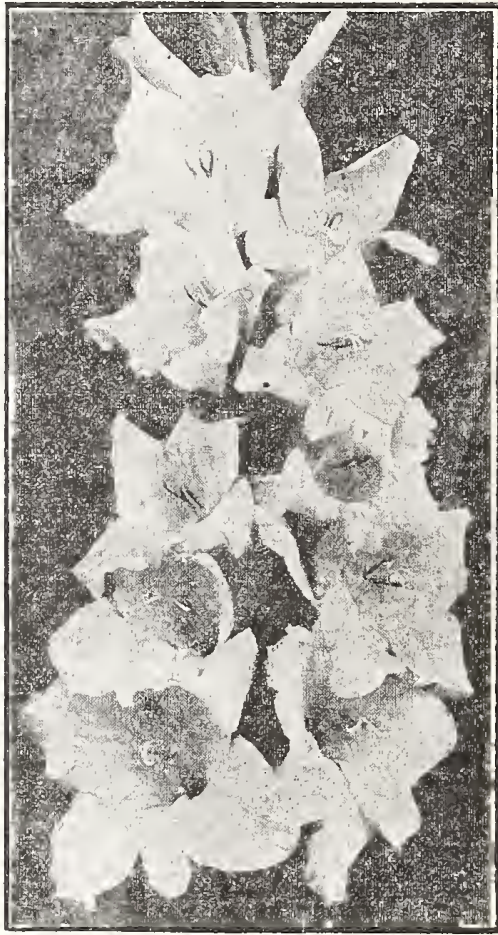

Le Marechal Foch

1430-Alice Tiplady. Adeep orangesaffron shading to buff in throat. Throat striped with russet-orange. This is one of Kunderd's Premulinus varieties. Very prolific. Classed as the best orange. $50 \phi$ per dozen; $\$ 3.75$ per 100 . Bulblets, $65 \&$ per 100.

1421-E. J. Shaylor. A pure deep rose-pink, beautifully ruffled. Probably the best pink in existence. 50 per dozen; $\$ 3.75$ per 100 . Bulblets, $65 \%$ per 100 .

1446-Mary Pickford. Named for "America's Sweetheart." Soft creamy white with throat faint lemon-yellow. Many flowers open at once. 35 per dozen; $\$ 2.85$ per 100. Bulblets, 50 per 100.

1499-Mona Lisa. A pale soft rosepink or blushed white; large, ruffled. Many open at once, $\$ 1.00$ per dozen; $\$ 6.50$ per 100 . Bulblets $\$ 1.00$ per 100 .

1427-Mrs. Frank Pendleton. A large rosy pink with red blotch in throat. Long spike with many flowers. 35 per dozen; $\$ 2.85$ per 100. Bulblets, 50 6 per 100

1462-Red Bird. A fine, big, wide open, bright red. Many blooms open 'at one time. 75 per dozen; $\$ 4.90$ per 100 . Bulblets, 75\& per 100.

1510-1910 Rose. A bright rose-pink with narrow central lines on lower petals. 35 per dozen; $\$ 2.85$ per 100 . Bulblets, 50 c per 100.

1524-Rose Glory. One of the finest of the ruffled varieties. A pure rose-pink deeper in throat. One of Kunderd's best. $\$ 1.00$ per dozen; $\$ 6.50$ per 100 . Bulb. lets, $\$ 1.00$ per 100 . 


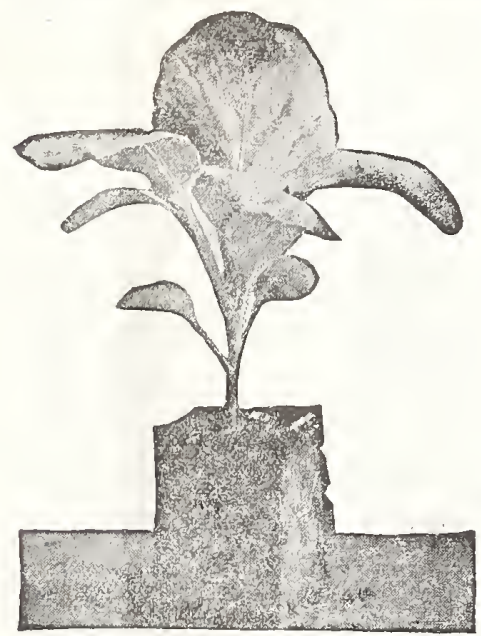

Cabbage Plant.

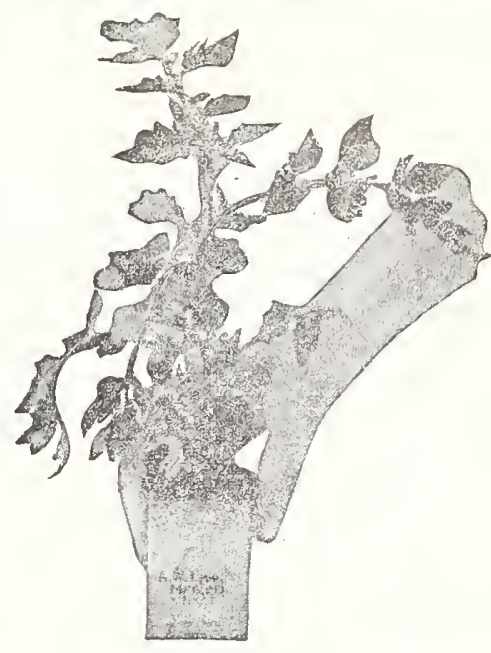

Tomato Plant.

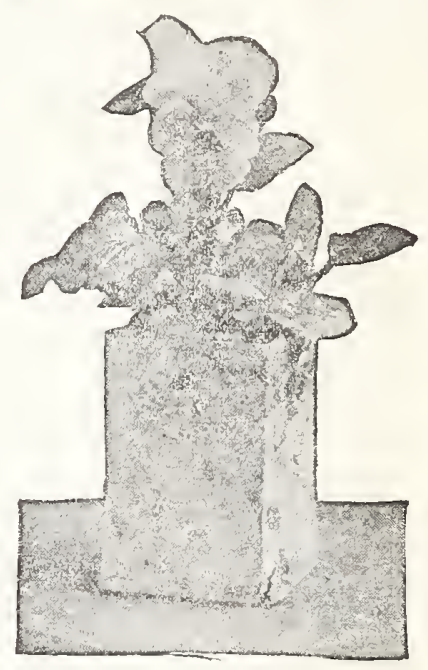

Pansy Plant

\section{Paper Pots for Plants}

These photos will give you a good idea of how these plant bands look in actual use. You can see at a glance what a great help they will be.

Potted tomato plants are increasing in demand and rightly so, for they sure do transplant nicely. Never wilt or lose a leaf. Generally they cost about $10 \mathrm{k}$ each if grown in regular flower pots, but you can grow them in these square paper pots at a very slight expense, and they will sell like hot cakes.

This shows how pansy plants look in square plant bands. Pansy plants are always good sellers and bring a good price in these pots, and the cost of the pots is very small. Also, it saves wrapping the plants separately, which would cost almost as much as the pots.

It is not so common to handle potted cabbage plants, but I believe we are overlooking something in that regard, and I believe that it would pay well. With the square paper pots we can do it cheaply, and I believe we can get out cabbage ten days earlier that way. Try it. The pots will cost you less than a quarter of a cent each in quantities.
These plant bands are all right. They are the finest thing in the world to transplant plants of every kind. They are cheap, easy to use, very satisfactory.

They come already folded and set up. All you have to do is open them, set them in a box close together, and fill with dirt and put in the plant. They can be had either with or without bottoms.

We do not bother with bottoms in them at all, but just use the sides, and we find they handle just as well when they are ready to move as if there were bottoms in the bands, and it is easier when they are in the dirt for the roots to get out on account of there being no bottom to the band.

They come in various sizes, but we like the $2 \times 2$ size the best. We can, however, furnish the other sizes if you want them. Here are the prices:

$2 \times 2 \mathrm{in.} \quad 3 \times 3 \mathrm{in.} \quad 4 \times 4 \mathrm{in.}$ Postpaid

$1000 \ldots \ldots$. $3.00 \ldots$ Exp. Collect
$5000_{\ldots} \ldots-13.50 \ldots \ldots$ Exp. Collect If you want them with bottoms, add $20 \%$ to all prices.

\section{Regal Lily}

This wonderful lily was well named for it is indeed a Royal specimen for anyone's gardien. Words are quite inadequate to do justice to its beauty.

The flowers are large, waxy and trumpet shaped. Its color is a creamy white, with a bright yellow throat. Outside of the flower is also white, tinted at the base with yellow. Each of the three large and three small petals has a delicate purple mid-rib. The Regal is a good bloomer. A bulb will produce as many as eight to ten flowers on a single stem. Stems are wiry and from eighteen to thirty-six inches tall. In fragrance the Regal Lily rivals Jasmine.

It was introduced by E. H. Wilson, of the United States Department of Agriculture, from the Mountains of Tibet in Western China. Here it grew under the plants. An existance on thin shale soil, most unfavorable conditions. In winter under these circumstances, has given to the temperature frequently goes to 40 us a plant which can be relied upon to degrees below zero, in summer the dryldo well most anywhere. It is free from wind and terrific heat make living pests and troubles of all kinds. I do not impossible for all except the hardiest of know of a single pest that can harm it.
To those of you who did not get Regal Lilies last fall, we want to say that spring planted bulbs will also bloom.

You will be six months ahead too, if you do it now, instead of waiting for next fall, and you know that sooner or later you will want a start of this hardiest and newest lily. A beautiful place to plant a clump is at the base of a Dorothy Perkins rose trellis, as they bloom at the same time and the combination of pink and white is exquisite. They are also good, planted with the pale blue Delphinium. The soil should be loose, and at least one-third leaf mould. The bulbs should be planted from four to six inches deep according to their size. Mammoth, three year old buibs $75 \mathrm{c}$ eack; good blooming size, two-year old bulbs, $40 \mathrm{c}$ each; two for 75c. If you are a good hand with plants, you might want to get some of our little one-year old planters that we set out in the spring to have ready to sell next fall as two-year olds. We will let you have them in dozen lots only, at $\$ 1.00$ per dozea. 


\section{Putting The "Pop" Into Popcorn}

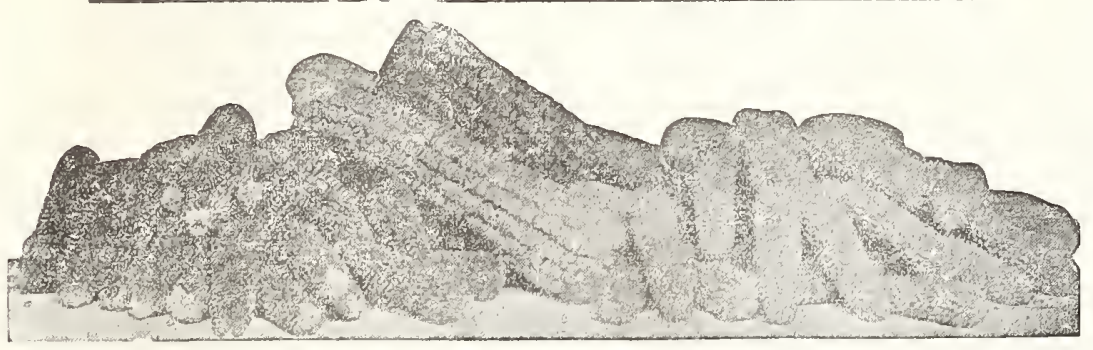

It will be a great help to have a good popcorn popper, but whether you use one or not, this is a mighty good way to pop your popcorn.

Use a rounding tablespoonful of lard and a little salt to two-thirds of a cup of popcorn. When the lard is good and hot, drop the corn in, stirring around and in a very short time it will go off with a bang.

Do not store your popping corn in a warm room. Store it outdoors. Out on the back porch is a good place, just so the mice don't get into it.

Everybody likes popcorn from $\mathrm{D}$ ad on down to the youngest member of the family. You should always have a good supply on hand. During the long winter evenings, after the day's work is done, when the family is all gathered in then a pan of snowy popcorn is appreciated by all.

Jap Hulless popping corn eight pounds for $\$ 1.00$, postpaid. Zone 1, 2 and 3. Outside of Zone 1,2 and $3, \$ 1.25$, postpaid.

Easy Popcorn Popper, \$1.25, postpaid.

No. 195 Japanese Hulless seed corn, packet $5 \mathrm{c}$; quarter pound, 15c; pound $40 \mathrm{c}$; five pounds, $\$ 1.50$, postpaid.

\section{Chrysanthemums}

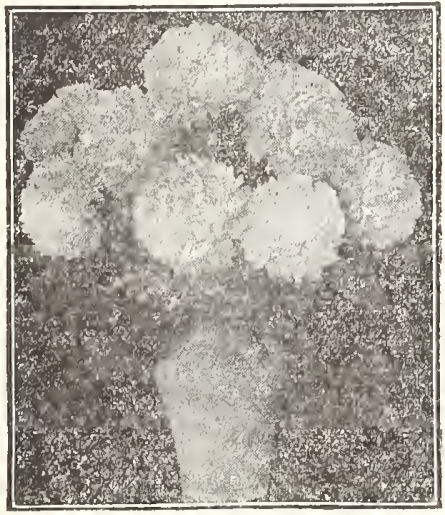

Due to some mistake on our part, we didn't get hardy chrysanthemums listed in the general catalog this year, but we have a nice stock of them in four colors, red, pink, white and yellow, and can fill all orders. Don't expect them to look like the picture above, though as the ones illustrated are the tender greenhouse chrysanthemums, and the ones we are listing in four colors are the old fashioned Lardy chrysanthemums, like my Grandmother used to raise years ago. Price 30 c each, or 4 for $\$ 1.00$, by mail, postpaid. Specify color wanted.

\section{Attention}

We are planning on putting in a line of work clothing, if interested write for full information.

\section{Siberian Iris}

Siberian Iris belongs to a different family, or rather a different branch of ing at the Seed House, and very often the Iris family from the German Iris. brings over samples of vegetables from The leaves are very much narrower and

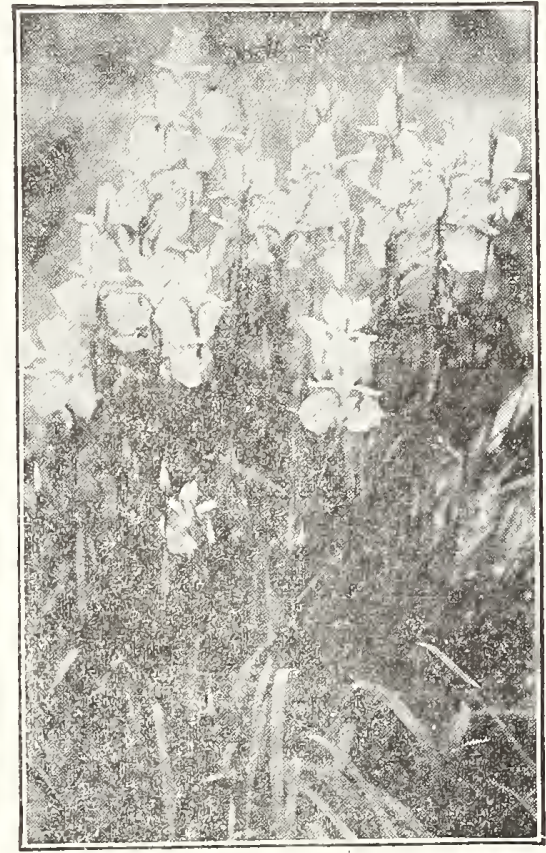

Last season he brought over a very early radish. The tops are very small, the radish slightly oblong with a little white tip, something like French Breakfast, but a smaller top and earlier. $\mathrm{He}$ claims he has grown radishes from this variety in seventeen days. He says twenty days is not unusual to produce nice crisp radishes.

He also states that he has grown this variety to seed and another crop from that seed all in the same year. Jim Smith is a good friend of the seed house folks and we know we can depend on what he says, so we do not hestitate to recommend this.

This is a German variety and we have imported some of the seed and are offering it under the above name. It is sold in Germany under a German name that we probably could not pronounce and would not understand. By all means try it out. Packet, $15 \mathrm{c}$; ounce, $35 \mathrm{c}$; quarter pound, $\$ 1.00$, postpaid.

\section{Verbena Hybrida Grandiflora}

Large blossoms, vigorous growers and wonderful colors. In selecting this strain for seed, if the flowers can be covered with a quarter the plant is discarded but if they are larger than a quarter, seed longer and more grass-like, and while is saved from the plant. That means the the flowers are smaller, they are borne flowers must be an inch in diameter or in great profusion. It comes in two more.

colors, a deep, dark, velvety blue and a 1248-Rosea. A pure pink with a white pure snowy white. Price, either color, eye. Pkt., $15 \%$.

15 each, or eight for $\$ 1.00$, by mail 1249-Blue. White eye, Pkt., $15 \phi$ postpaid. Specify color. 1250-Mayflower. Pink. Plet., 15 \&. 


\section{Our New Dahlia Varieties}

\section{Cactus}

1878 Brunhilde. Finely formed flower of rich plum color. An unusual color not often seen in cactus dahlias. Jow growing plant that does not blow over. Free bloomer. Each, 35c; Doz., \$3.50.

1879 Indomitable. Large flowers of rosy mauve. Early and free blooming. Has an appealing richness that is much admired. Each 60c; Doz., \$6.00.

$1880 \mathrm{~J}$. H. Jackson. The narrow incurved petals are rich, velvety, blackish maroon. The flowers of this almost black dahlia are freely borne on long wiry stems and are richly beautiful. Each, 25c; Doz., \$2.50.

1881 Libelle. The numerous flowers are composed of incurved petals purplish-rose. A distinct and pleasing color. Each, 35c; Doz., \$3.50.

1882 Magpie. It should be wine red with white tips, but, like all bicolored varieties, it does not always do as it should. The two colors are combined differently in almost every flower. Each, 35 c; Doz., $\$ 3.50$.

1883 Madam Aymard. Flowers of a peculiar color hard to describe. Pale Iilac with a golden suffusion. Petals rather broad and moderately incurved. An unusually distinct variety. Each, 35c; Doz., \$3.50.

1884 Rev. Williamson,. One of the darkest of dahlias. Appears as if the minister had officiated at a funeral and was wearing his Prince Albert coat. The flowers are full and are composed of moderately incurved petals and are
blackish maroon in color. Each, 35 ; Doz., \$3.50.

1885 The Eagle. Large fluffy flower of soft sulphur yellow with long stiff surplus, we are making a special price stems. Has good keeping qualities as bclow:

a cut flower. Presents you with many a blossom during the season. Each, 75 ; Doz., $\$ 7.50$.

\section{Pompon}

1886 Amber Queen. A little beauty, Rich, clear amber, sliaded apricot. Free Bloomer with long stems. One of the best "pom

1887 Darkmess. Probably the darkest pompom of all, being a very dark maroon. The flowers are freely prodinced and are borne on extra long, sirong, but slender stems. Each, 35c; Doz,, $\$ 3.50$.

\section{New Dahlia Varieties}

A prominent Ohio dahlia grower $\mathrm{dc}$ cided to quit the business and offered his stock of dahlias consisting of somcthing over threc hundred varieties, and we bouglit the entire list. This collec. tion contains a lot of the standard varie. ties and some of the very rare and high priced sorts.

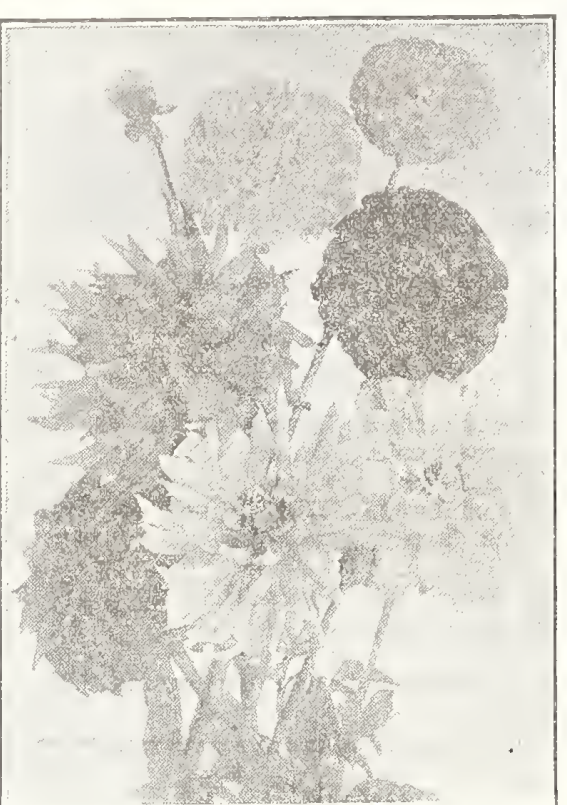

We expect to plant a few of every variety on this list over on our sandy land bulb farm where we grew our gladiolus bulbs and other bulbs last season. If you can possibly arrange to do it, we want you to come over and visit is when the dahlias are in bloom.

We will use some of these for planting stock for our crop next year, however, we will have more than we want to plant so will dispose of a lot of them right now, and to be sure to move this

\section{Special Dahlia Offer}

The following special price does not apply to varietics listed in the catalog. We will offer the following list as quoted either single bulbs or by the dozen. However, if you wish to make up a col. lection amounting to $\$ 2.00$ or more, we are willing to allow you to sclect your varieties and will makc you a big reduction.

Orders for \$2.00 or more, select \$1.00's worth extra.

Order's for $\$ 3.00$ or more, select $\$ 1.50$ 's worth extra.

Orders for $\$ 4.00$ or more, select $\$ 2.00$ 's worth extra.

Orders for $\$ 5.00$ or more, select $\$ 2.50$ 's worth extra.

The above prices postpaid and cach varicty carefully labelled. As we never cxpect to plant anywhere near all of this lot, we have lot of $1 \mathrm{hcm}$ to dispose of this season.

\section{Decorative}

1866 American Beauty. One of the most freely blooming dahlias in our garden. The plants are loaded with large blossoms of American Beauty Rose color from early in the season until Jack Frost takes them. Each, $35 \mathrm{c}$; Doz., $\$ 3.50$.

1867 Dr. Tevis. Flower of enormous size held erect by long, sturdy stems. The color varies according to the situation and season, being a shade of soft salmon-rose suffused with gold, shading to a golden apricot center. The plants are simply laden with these giant blooms until one wonders how it is possible for one plant to produce so very many flowers of such a large size. Wie can unreservedly recommend the Doctor. Each, 75c; Doz $\$ 7.50$.

1868 White Swan. A florist's favorite. The flowers are not extra large, but are of a size useful in design work and are produced in profusion. As the name suggests, they are pure white. Each 25c; Doz., \$2.50.

1869 Dr. Tyrell. A peculiar bronze color, difficult to describe. Large flowers freely produced. No other dahlia of our acquaintance has just this color. Each, 35c; Doz. \$3.50.

1870 Frarces Lane. A beautiful, light, velvety lavender-red flower with pale lavender streaks running down through the petals, which are very broad and flat with the tips slightly curled. A very free bloomer with long, wiry stems. A vase of these flowers makes a sight long to be remembered. Each, $35 \mathrm{c}$; Doz., \$3.50.

1871 Le Grand Manitou. Ore of the most popular of the variegated dahlias. The large white blossoms are striped and spotted with purple. Sometimes the blossoms come solid purple in color. The plants are low and do not blow over. Each, 30c; Doz., \$3.00.

1872 Queen Esther. A delicate shade of rose pink with a sheen of pale gold. Exceptionally free flowering. The flowers are carried on stiff stems and are wonderful cut flowers. She's the dainty, demure queen of our hearts. Each, 50c; Doz., $\$ 5.00$

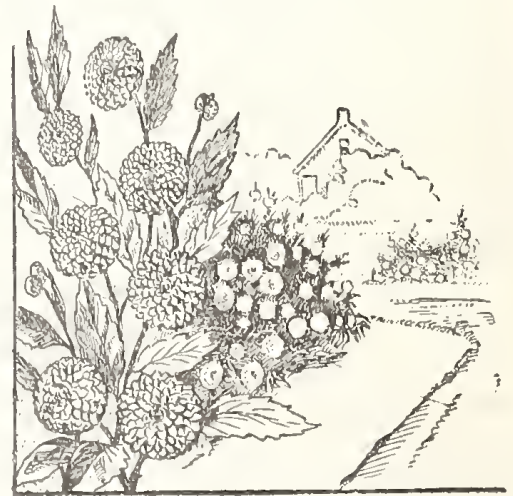




\section{Watch-Em-Grow Plant Food}

Are your house plants as nice as you would like them to be, with the flowers as bright and the foliage as rich? Have you ever wondered why some people have more beautiful plants than others and why some folks seem able to make any kind of a plant do well? Do you know that Watch-Em-Grow Plant Food will work wonders with a sickly plant? Try it and you will be amazed at the results you will see in a very short time.

Where Shall I Use It. All plants from a tiny blade of grass to a large tree will be benefited by drinking of this food. But indoor plants always have a greater

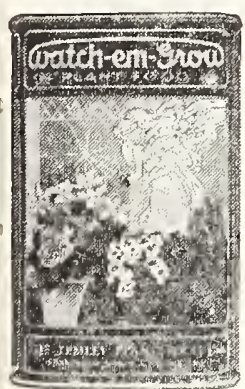

struggle to succeed than do outdoor plants, and as we have nothing but indoor plants for several months each year, perhaps the greatest use you will find for Watch-Em-Grow Plant Food is on the house plants and cut flowers indoors. But don't overlook the use of it on your roses, bulbs and shrubs.

How Do I Use It. Being a clean, odorless powder, which will dissolve quickly in water, it can be easily applied to plants just as you ordinarily water plants. Complete instructions on each package, but following suggestions will show its value.

For Potted House Plants. Dissolve a rounded teaspoonful in a cup of hot water, pour this into a gallon of good water and you are ready to feed your plants. For a plant in a six-inch pot, a pint every few days until you see a decided improvement then use every month or so.

For Your Garden. Both flowers and vegetables will be greatly benefited by Watch-Em-Grow, in the same solution as recommended for house plants, is sprinkled over the seeds before they are covered.

Cut Flowers. Drop a pinch of Watch-Em-Grow powder in the water. It will make the bouquet last longer and will be worth the price of the food.

In Potting. When you change the soil of pot plants, mix a teaspoonful of Watch-Em-Grow with a gallon of soil before you set the plants.

For Your Lawn. If you have spots in your lawn where it is hard to keep the grass green, sprinkle with the solution and you will be surprised at the results. Price, big 8-ounce can

$50 \mathrm{c}$ postpaid

\section{Popular Perennials}

Of course you are going to have a perennial garden this year and probảbly you have already decided to save money and nerve strain by getting the collection printed in colors inside the back cover of the catalog. Just look it over again! It has the best of the "old" things and a lot of fine novelties. Some for bloom in every month and even something for winter bouquets. They are all sturdy, live plants that will bloom this year and then "live over."

We know you will want to arrange them just right and so we have had the Landscape Department draw you this planting plan. The tall plants are at the rear and the lower ones in front. You should add a low narrow border of some annual edging plant such as Sweet Allysum.

The plants will seem far apart in the early spring but with good cultivation will cover the ground by fall.

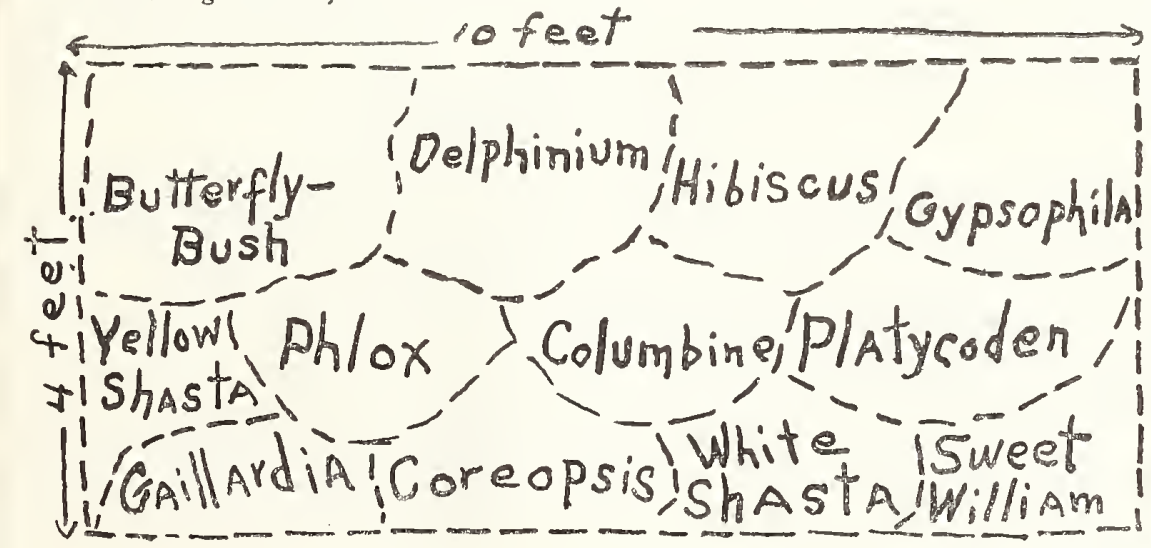

German Iris Madam Chereau

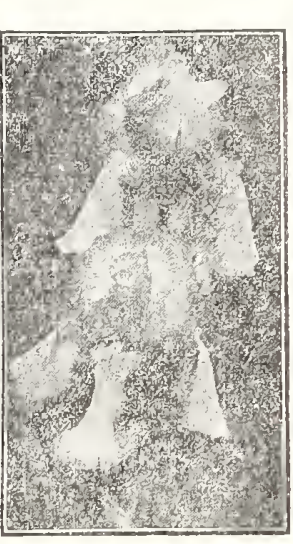

To my notion, Madam Chereau, although it is one of the older varicties, is one of the best in the list. In color, it is a pure snowy white with the edges delicately tinted with lav. ender and frilled, or waved some. what. You can get my meaning better by looking at the picture. $M$ a d a m Chereau, also goes under the name of Fairy Queen. We have been working up a stock on this variety for several years and have enough now to fill all orders. Price $15 \mathrm{c}$ each, or, 8 for $\$ 1.00$, by mail, postpaid. You really should buy at least 8 to make a nice row of them. Plant them about a foot apart and by next year the row will be filled in solid, as they increase very rapidly.

\section{Delphinium Belladona}

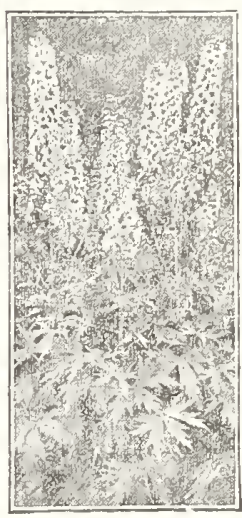

Someone has truly said that the Delphinium is the Queen of the Summer garden. A wellestablished plant will grow to be six feet tall without any trouble. It is an educated relative of Grandmother's annual Larkspur. The main difference is that this one comes up perfectly hardy from year to year and grows so much taller and handsomer.

We are handling Delphiniums in three different strains this year, the one illustrated, being known as the Belladona, which is a beautiful, pale, azure blue. The variety known as Bellamosum, closely resembles the Belladona, in habit of growth, except the flowers are a very dark, velvety blue, some with a black eye and some with a white eye.

The finest of the lot, however, are the English Hybrids, these are very large flowers and over half of them come double, in the most beautiful shades of pink, and light blue and some even pure white. The English Hybrids are priced a little higher than the Belladona and Bella mosum, but they are worth it.

See our general catalog for prices. 


\section{Crib Corn Killed By Decenber Freezes}

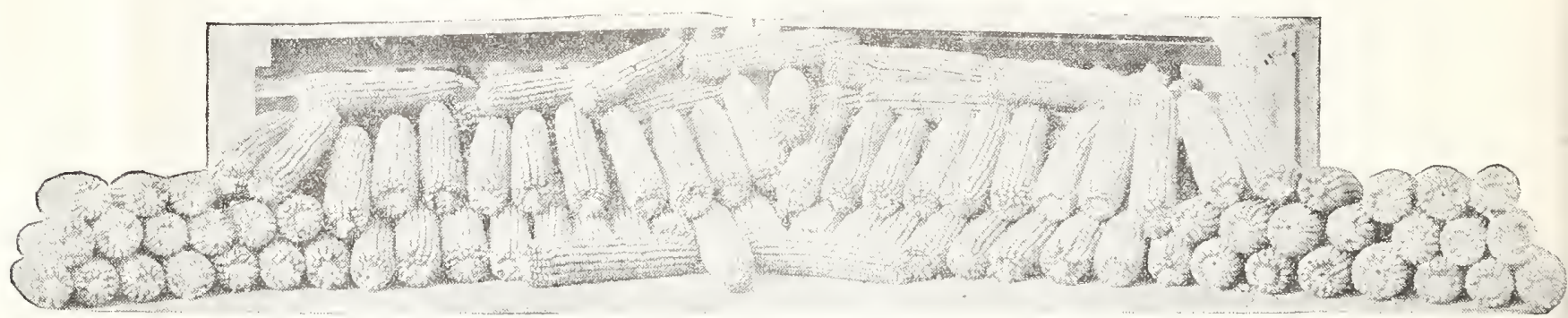

\section{Crib Corn Dead}

We are faced right now with the most baffling seed corn situation in years. I thought until about a week ago most anything would grow. But from tests taken about January 15th from 15 bunches of crib run corn only one lot tested $90 \%$ and some as low as $60 \%$. It looked like good sound, dry corn suitable for seed, too. The surprising thing was that the worst looking lot tested highest. That shows how easy it is to get fooled by guessing or depending on eye tests. They won't do this year. Get generous samples, sprout them, count the sprouts and judge for yourself.

The trouble was caused by the wet fail which kept too much moisture in the corn and the hard freezes during December and early January froze and killed the germ. I can see no other way to explain it.

\section{Missouri Corn Bad}

The Missouri Corn Growers Association says, "The seed corn situation in Missouri is quite serious. The tests which we have made to date have averaged lower than last year, and that means they are low, indeed." If Missouri corn is poor the states north must be much worse off.

This is a year you can't tell by looks, you must test, and right now is the time to get busy. I never saw anything just like it, but it's here and we have to make the best of it. If you have early hung corn you are probably all right but test it. If you failed to hang your seed and have to buy, better order early as we never have enough hung seed to go around. We may find enough seed to carry us through the season but to be right honest with you I don't know where more will come from when our present stocks are sold.

\section{CORN TO SUIT YOUR SOIL AND CLIMATE}

No maiter where you live we have corn that will mature well and make a good yield for you. Most of the failures in seading away for seed corn can be traced to the grower picking what he thinks he wants rather that what he needs. If in doubî which to choose tell us the nature of your soil and the color you want and we'll use our best judgement in filling the order. If local grown strains don't rii your needs we will fill from early northern grown seed. Be sure you get corn that will mature for you.
I haven't room here to give long descriptions of all the kinds of Seed Corn we have but will be glad to send a copy of our Seed Corn Booklet which gives descriptions in detail. Ii's free for the asking. We will also be glad to send small samples of any of these varieties on request.

\section{Standard Main Crop Varieties}

Caktle Corn. New strain from Nebraska. Long smooth ears, beautiful grain. Best yielding yellow for thin land, Matures in 100 days. Easy to husk. Write for leaflet with pictures. Sample Free.

Improved Shemandoah Yellow. Wonderful new disease resisting selection. Big yielder, deep grain, healthy, vigorous grower. My choice for main crop yellow. Matures well anywhere south of Des Moines.

Krugs Yellow Dent. Great new corn from Illinois. Medium sized ear. similar but slightly smaller than Reids but heavier yielder.

Reid's Yellow Dent. The standard show type corn of the corn belt. Fairly large, yellow, medium rough ears.

Shemandoah Yellow. Large, fairly rough, yellow cattle corn. Heavy yielder.

Shemandoah Special. Similar, but smoother, and about 10 days earlier.

Cormplanter. Finest of all white corn. An improved strain of Boone. Longer ear, beautiful grain.

Boone County White. Deep grained, rough, extra large ear. For good land.

Iowa Silvermine. Medium size white. Good for old or thin ground. Stands dry weather well and makes a crop where others fail.

St. Charles White. Red cob, white corn, strong grower. Great for fodder or ensilage. Very popular in Missouri.

White Elephant. Long, smooth, white, stands hardships well.

Improved Calico. Striped, red and yellow, fairly early.

All of the above are home grown here in Southwest Iowa and are the best varieties grown here.

\section{Standard Main Crop and Early Varieties}

These prices are for the Standard main-crop varieties and the early kinds described briefly on this page and in detail in the Seed Corn Booklet which will be sent on request. This is strictly first class seed, extra selected, butted and tipped by hand, shelled and triple graded, tested before shipping and tests marked on each sack. Prices are f. o. b. here, sacked in strong new sacks. Sacks weighed in free. You pay the freight or express. (If wanted by parcel post, add postage).

We will make the following special prices on standard and early varieties

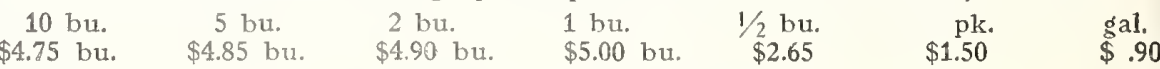

\section{Early Corn - 80 to 90 Days}

These are the varieties for planting in the extreme North, or for replanting, or for extra early feeding corn from here South. Most can be furnished in either homegrown or Dakota grown. The Dakota seed is generally earlier but smaller. Please specify if you have any cloice. All same price.

Red 90-Day. My choice for the best extra early corn. Always ripens and makes good yield and fine feed.

Northwest Yellow Dent. Withoul question the highest yielding and best quality early yellow corn on the market. Very early.

Pride of the North. Small, yellow corn. Earliest of all. An old favorite.

Silver King. The standard white corn for Northern Iowa. Similar to Silvermine but smaller and earlier.

Flint or Yankee Corr. Small, slim, smooth, hard ears. Earliest of all corns. We have both yellow and white. 


\section{Small Ears Grow Best}

On account of the big ears being so wet when the freeze came, the smaller ears and the smaller grains are the ones that grow best this year and where it was necessary we have sacrificed size for good germination.

\section{Treat Your Seed Corn With}

\section{Uspulun Or Bayer Dust}

These are chemicals used on seed corn to kill the seed borne fungus diseases. Stimulates the growth, increases the yield 5 to 10 bu. per acre and improves the quality by preventing moldy, diseased ears. Also helps keep mice, squirrels, moles and other pests from bothering the seed before it comes up.

Uspulun is the wet treatment or soaking process. One can treats about 5 bushel of seed. Price $\$ 1.60$ for $1 / 2$ lb can.

Bayer Dust is much the same kind of treatment but is dusted on the seed instead of soaking. (We think the Uspulun or soaking treatment is best.) One can Bayer Dust treats 5 bushel seed. Price $\$ 1.75$ for $1 \mathrm{lb}$ can.

Either must go by express at your expense or if you order seed corn it will come in the sack with the corn.

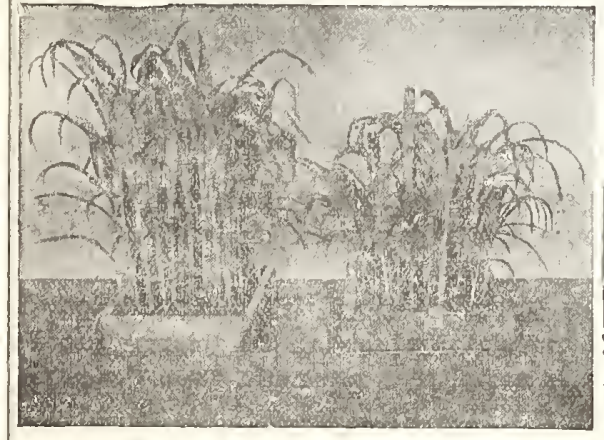

TREATED

UNTREATED

\section{LETTERS}

"Last year I treated half of my corn with Uspulun. The corn I had treated with Uspulun yielded 75 bu. per acre, showed crop, for I can't be there to plant it and less rotten corn and the stalks were strong tend it, but you can take the seed home. and big, but the field with untreated seed and examine it and test it and call in the SMALL AMOUNTS OF SEED CORN yieldcd only 65 bu. per acre with smaller neighbors; and if you feel that you have Shelled Seed - Large packet 10d; stalks and more nubbins; the ears were been beaten, you can have your money pound, $25 \xi ; 3$ pounds one variety, 65ל; not so big, more ear rot and down stalks. back. That's fair. All I ask is, that you 5 pounds, $\$ 1.00$. Specimen ears, $40 \phi$ Uspulun sure is the real dope." give me a fair shake, and I will leave each. These prices apply to all varieties, Fred Wendelsdorf, Jackson, Minnesota. matters in your hands. postpaid, anywhere in the United States.

"Regarding the Uspulun I got from you last spring, unsed it on 30 acres of corn and am sure it made lots of difference in the yield and the insccts don't bother the seed neither does the mice or moles. Found a good many dead mice that had been poisoned with it. Won't

plant corn without it now." We grade our corn and make it as near perfect as possible, but of course, not all

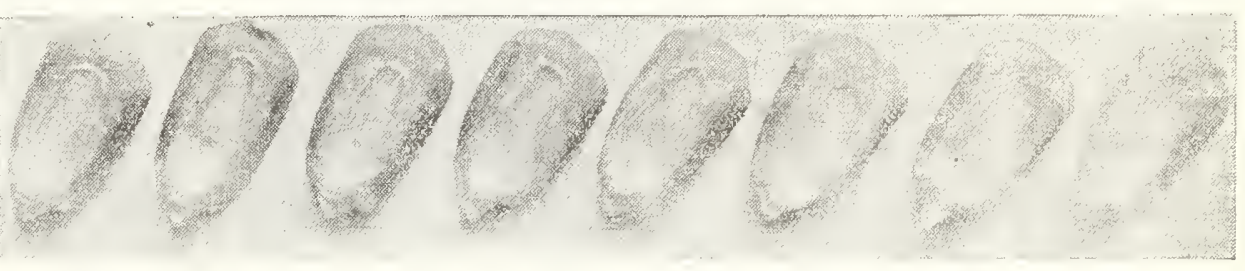
$J$. R. Easterly, Albany, Missouri. varieties are as big as these specimen grains from our Improved Shenandoah Yellow. 


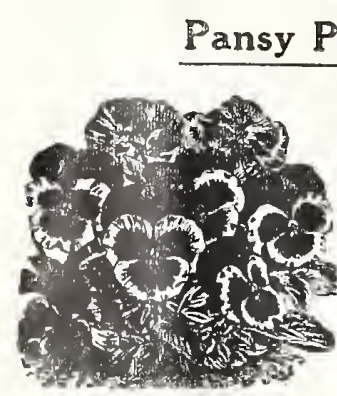

Pansies
We will have thousands of pan. sy plants for ship. ment after April 15th. They are grown from the finest strain of seed and we can assure all lovers of this beautiful flower that they will be surprised and pleased with the size and beauty of this strain of pansies. They will be sent by mail, extra well packed, and safe arrival guaranteed.

1 dozen, mixed colors, postpaid _. \$ $\$ .75$

3 dozen, mixed colors, postpaid . -2.00

\section{Flower Plants}

Wie can also furnish the following flowering plants at prices listed below: Asters, mixed or colors -.- 50c doz Salvia, or Scarlet Sage _...\$1.00 doz. Verbenas, mixed colors $\ldots--\infty 1.00$ doz. Moonvines, white _....- 1.50 doz. Geraniums, red for beds _- 2.40 doz. All These Prices Postpaid

\section{About Our Tomato Seed}

In the Spring of 1925 I planted one square rod of ground with tomatoes grown in our house from seed of the Field's Early June variety. These plants provided all the fine tomatoes we could use and can from July 15 to October 1, and we sold eight dollars worth to our neighbors as well. As the plants were all well removed from any other tomato plants I saved a fine large specimen for seed which was in turn planted in our honse this spring. (1926). This time my plot was one rod and one-third, partly on the same ground, and although this has been a hard summer here the result is almost unbelievable. We began picking on July 15 and at the same time selling and buying other fruits and goods up to the first 200 pounds of tomtoes. Here is the product of our 1 1-3 rod of ground plus some good Field's Early June tomato seed: 1 bushel Wine Sap apples, $\$ 1.65 ; 1$ bushel peaches, $\$ 2.25 ; 2$ baskets plums, 90r; $1 / 2$ bushel pears, $\$ 1.10 ; 2$ gallons Loganberries, $\$ 1.30$ 4 baskets grapes, $\$ 1.25 ; \$ 2.00$ worth of sugar and \$5.55 in groceries. We have eaten tomatoes since July 15 and are at it strong yet from same plants and have 17 quarts in cans to last the next year. The ground is yet peppered with green ones caught by the early frost. If you have any better record for your seed than this I would like to see it. If you think you can beat it well hop to it.

A. F. Howell

\section{The "Electrol" Oil Burner}

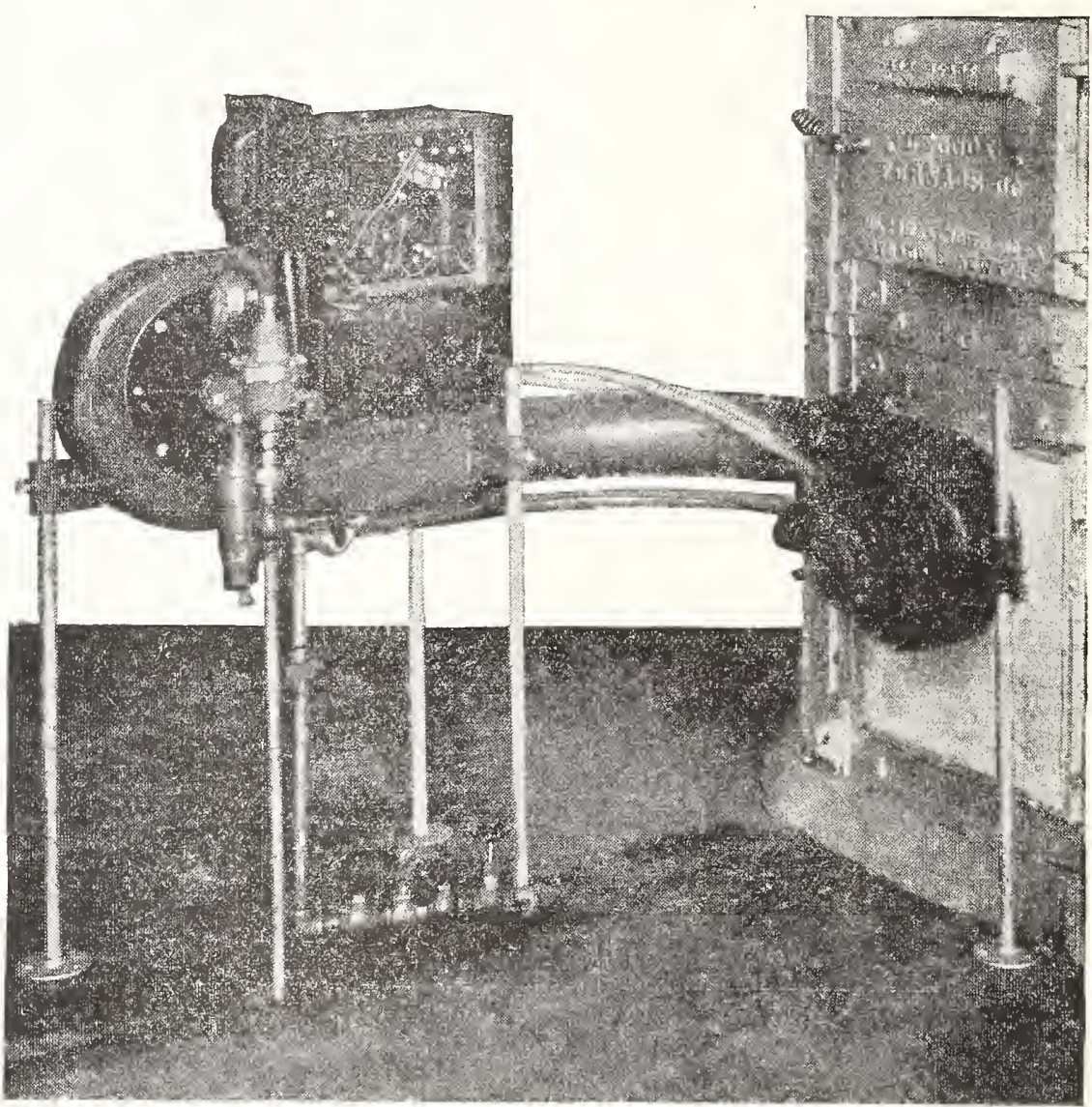

This is the Electrol oil burner I have been telling you about from time to time. We have tried several here at the Seed House and at my house, and this one has it over the others in every respect

Burns any kind of fuel oil that will flow through a pipe. It's quiet and automatic. All I do over home is keep the thermostat upstairs at the temperature I want. Then, the Electrol does the rest. It is completely automatic, even down to having an electric spark starter instead of a gas pilot light.

About the best thing I can say about Electrol is that I have had it all winter so far and don't know anything about it. Now, you know if we had any trouble, then I would know more about it. The Electrol is just down stairs doing what it's meant to do and if you want to know how it works and what it's like, you'll have to write me for the little booklet furnished by the Electrol people. It's a dandy, best I ever knew.

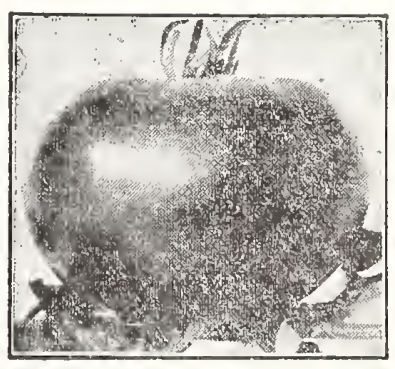

A Perfect Specimen of the Early Veriety

\section{Tomato Plants}

We are having a nice lot of tomato plants grown here at Shenandoah, and we will be able'to fix you out in good shape. They will be ready about April 20 th, or possibly earlier

Tomatoes-(heavy transplanted plants) delivered by farcel post, postpaid, 6 for 30c; 12 for 45c; 25 for $85 \mathrm{c} ; 100$ for $\$ 3.00$.

Varieties: Early June, Mississippi Girl, New Stone; Earliana and Red Head. Also Pepper, Eggplant and Cauliflower at the same price.

Frost Proof Cabbare Plants: See page 20 of the catalog and Seed Sense for prices and varieties 


\section{Try Something New}

Have you thought of a hedge of the a. sentimental spot for the Hollyhock, in spite of its brief blooming period and its seedy appearance the rest of the year. Why not be modern and bestow this Hollyhock sentiment on its up-10-date cousin, the liardy Hibiscus. It has much larger blooms in a wonderful range of colors and is at all times neat, sightly and perfectly hardy. It begins to open its gorgeous blooms in July and keeps it up until frost. The leaves are large and exotic looking.

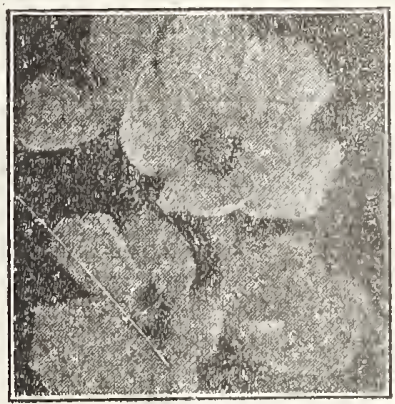

\section{Hibiscus}

It makes a beautiful division hedge, blooming at a different season from all other hedges.

Because we want you to get acquainted with it and because we have a large stock, we are making a bargain offer that will amaze you. Only \$2.00. dozen postpaid. Of course we couldn't sell less than a dozen at this rate. It is about the cheapest division hedge that you could have besides being so beautiful. Set the plants two feet apart for this purpose and remember that they are very slow starting. They likc plenty of moisture and rich soil.

\section{Our Big Phlox Offer}

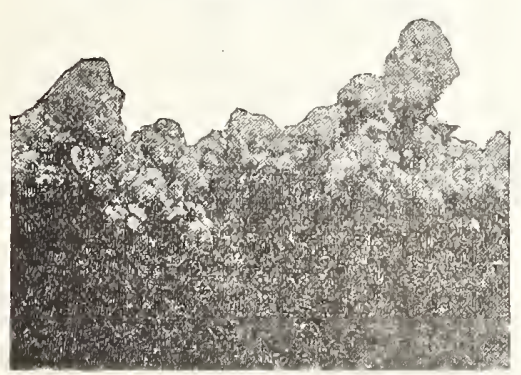

Hardy Phlox beautiful hardy Hibiscus? We all have

\section{Hardy Perennials}

Achillea. The Pearl-This grows abou a foot high and has clusters of little double white flowers the size of a dime It thrives on hot weather, and is just exactly the right flower to combine with Gladiolas for cut flowers. It multiplies rapidly, is fine on graves.

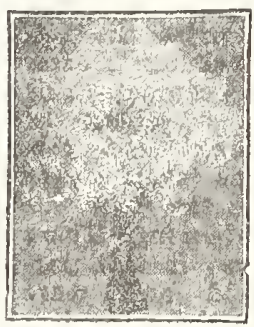
Gypsophila - Babys Breath. You cannot plant too much of this. It softens every summer bouquet and when dried for winter use is in great demand. The name is from Gypsum as it likes lime. Do not set in sour soil. The favors at Jessie's Wedding Gypsophila were of Gypsophila and Perennial Sweet Pea.

Perennial Sweet Pea-We cannot have roses that bloom all summer on our porches, in this climate, but we can get the same pink and white glory with the Perennial Sweet Pea. Plant them liberally on your trellis with other vines where they give flowers during the hot July ant August days when bloom is scarce.

Hardy Chrysanthemums-The last
flower to bloom in the garden, and fine to lift and bring into the house for blooms over Thanksgiving time. Clip them back in June for bushy plants. Pink, white red or yellow.

\section{BLEEDING HEART (DIELYTRA SPECTABILIS)}

You all are acquainted with the old fashioned favorite, which blooms so

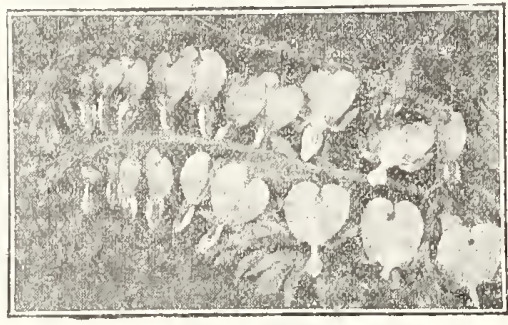

Bleeding Heart freely and does so well on the north side of the house, where the sun never strikes. Some times we have trouble in getting a good supply, but I think that wc are well ship it at the earliest proper time. enough supplied this year to fill all Twenty big strong plants for $\$ 5.00$ postorders.

Wie also have succeeded in obtaining a stock of the new fern leaf, bleeding heart, which is a cross between the old fashioned Dutchman's Breeches and the old bleeding heart. It grows tall like the f bleeding heart but the leaves and flowers are more like Dutchman's breeches and it admired in our fields last summer. Our is ever-blooming. It blooms from spring
choice of varieties. Six for $\$ 1.00$ post- until frost. See prices in our general admired in our fields last summer. Our is ever-blooming. It blooms from spring
choice of varieties. Six for $\$ 1.00$ post- until frost. See prices in our general catalog for both.

Beautiful Blooming Hedges

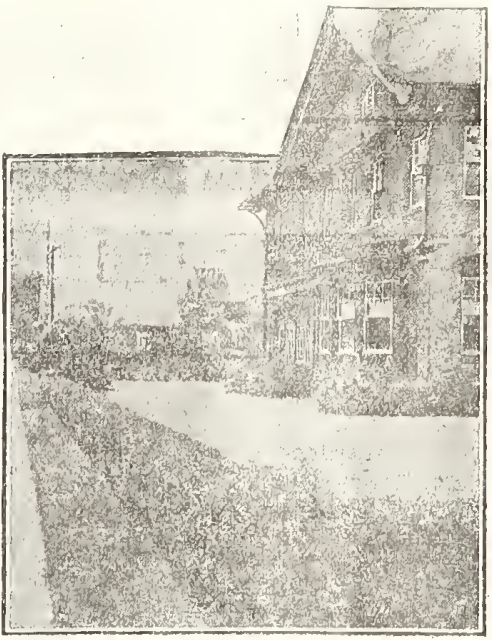

Privet Hedge

Cheaper than lumber!. I'll say. Did ou know that for only $\$ 5.00$ you could fence your fifty foot lot away from the alley with a wall of living green? Set If you want it tall, use bush Honeysuckle, which will have dainty little pink flowers in the spring followed by red berries all summer. If you want it medium height, nothing is prettier than Spirea Van Houttei, which you probably know by the name of "Bridal Wreath". If you want a lower licdge but one that will be boy proof and dog proof, use Japanese Barberry.

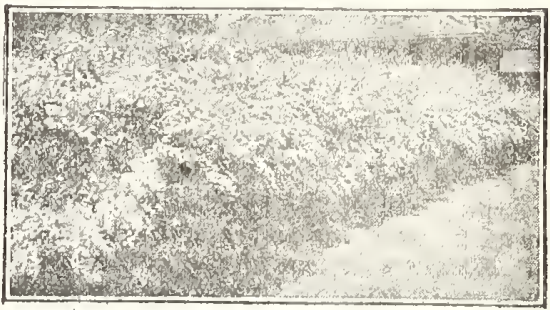

\section{Spirea Van Houttei}

The earlier you want to plant your hedge, thc better chance it will have to paid. Obey that impulse. Pin a five dollar bill to your letter and get your order filed.

Six named varieties of Hardy Phlox for $\$ 1.00$.

No one wants the old Magenta Phlox any more. These are the new shades of red, pink and amaranth that you saw and paid; all different.

\section{Japanese Mountain}

\section{Chrysanthemums}

The early blooming kind. Sure to bloom before frost. They require a little winter protection in exposed places, but are real treasures. Yellow or Pink, $50 \mathrm{c}$ each. 


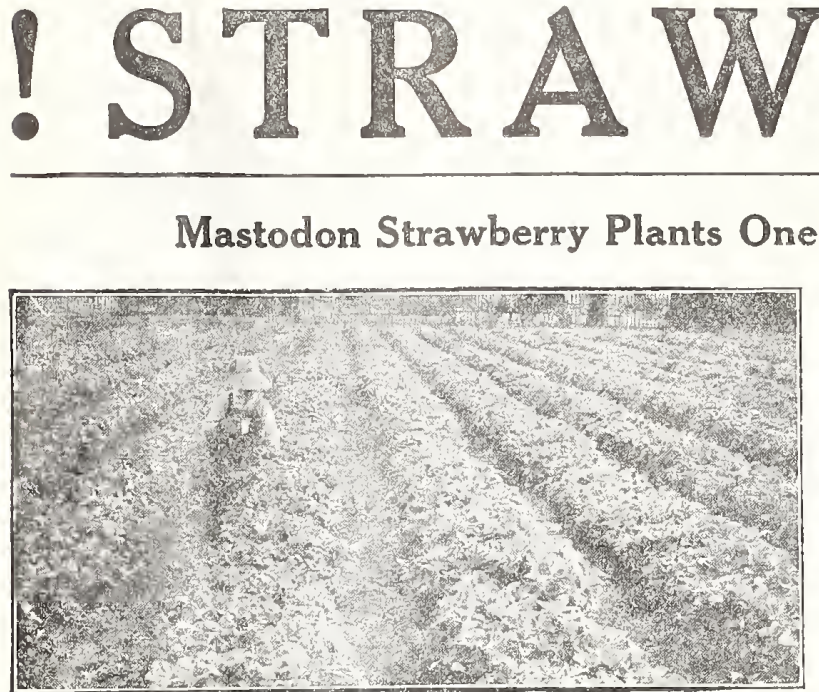

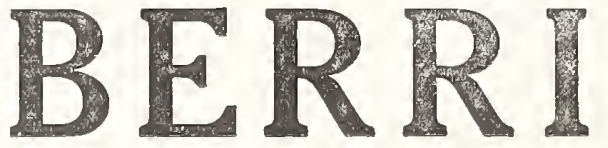
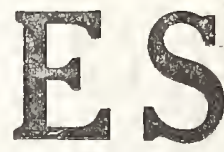

\section{Mastodon Strawberry Plants One Year Old}

October 20 of this season, had produced more than 600 cases of berries, or more than 10,000 quarts

The patch was set in April, and ripe berries were picked on July 11, within 90 days from the time the plants were put into the ground. The patch was picked over every four days during the summer and by the first of August, the yield had worked up to about 160 quarts per acre every four days, and at that time they sold for 30c per quart.

In spite of the dry weather in the early fall, 36 cases an acre were picked at one picking during the first week in September. These berries sold for $\$ 6.00$ for a 16 quart case, netting $\$ 5.30$ to the grower, after transportation charges were paid, but the cold, cloudy weather in October brought the yield down to 5 cases to the acre during the first week of October.

Some of the berries in this patch measured as high as five inches in circumference, and at one time, nine of them were found which covered the top of a one quart berry box and eighteen of them filled the box from top to bottom, and from side to side. Three of the berries weighed two ounces and five placed end to end measured eight inches.

It is this large size and great productiveness that makes the Mastodon stand ahead of every other ever-bearing sirawberry.

Lots of people write in and want to know what is the best kind of soil to plant strawberry plants on. Any soil that grows a good paying crop of corn, oats or potatoes will grow Mastodon strawberry plants successfully, but the most ideal of all is a rich moist, sandy, cool loam. Gravelly and clay loam will also grow Mastodon successfully but more organic matter has to be added to make them more open and workable, Organic matter can be applied in the form of straw, fodder, leaves, well rotted manure and things of that kind.

Regardless of the kind of soil they are set in, the plants should never be allowed to want for water or food. Keep them always in a thrifty vigorous, condition. Moisture is one of the necessary requisites for successful Mastodon culture. Select, when possible, a rich, sandy loam soil underlayed to a depth of one or two feet with a water sand, such a soil is always moist and cool.

Naturally you folks throughout the Middlewest here can not always find a soil that is underlayed with sand, so the next best step is to see that they have plenty of water applied artificially. Remember that strawbrries are more than 90 percent water and no strawberry plant can produce a good crop of fruit without plenty of you give them plenty of water. If it doesn't fall naturally from the skies, you will have to apply it artificially in the form of irrigation, and if you are not fixed to irrigate your strawberry plants, don't expect much of a crop throughout the summer.

Of course, when the fall rains come, they will go ahead and bear another crop, but given half a chance and plenty of moisture and they will bear all summer long.

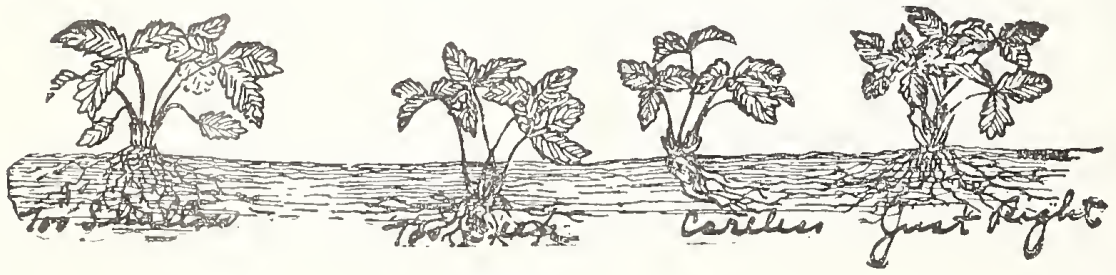

This shows just how the plants should be set for best results.

\section{Mastodon Strawberries}

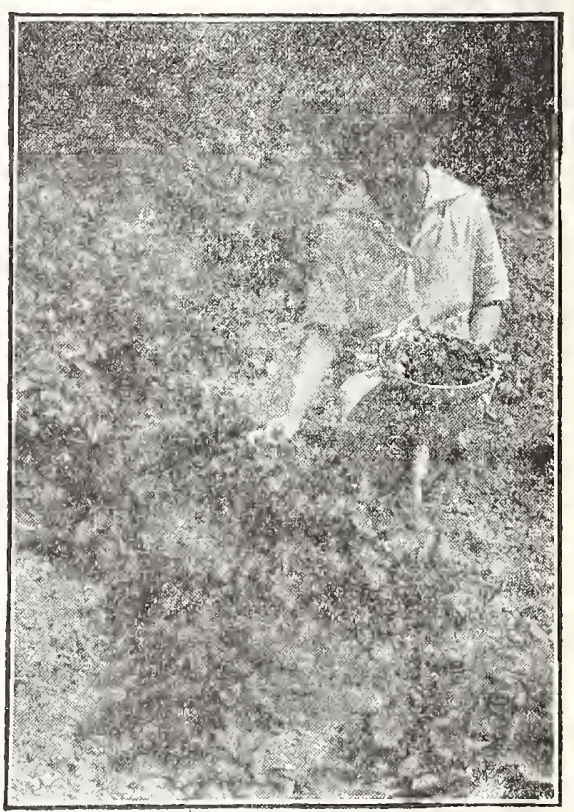

This picture shows Mrs Kieth of Sawyer, Michigan, picking Mastodon Strawberries on the 20th day of October. Notice the size of the berries in the pan. There are fifty plants in the two rows shown in the picture and she has picked a gallon pan full from the fifty plants, at this one picking.

\section{Mastodon Strawberries}

Prices of Genuine Mastodon Everbearing Plants Postage Paid.

$12 \ldots \ldots+00$ 3.00

$25 \ldots .02$

Ask for prices on larger lots.

\section{Exact Average Size of}

\section{Mastodon Strawberries}

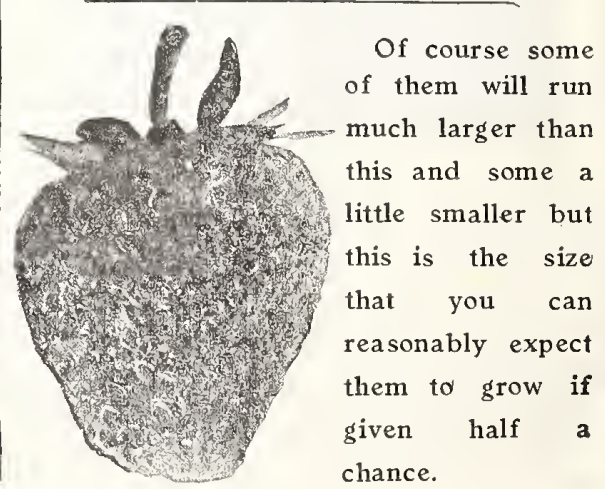




\section{Perennial Plants For The Rock Gardens}

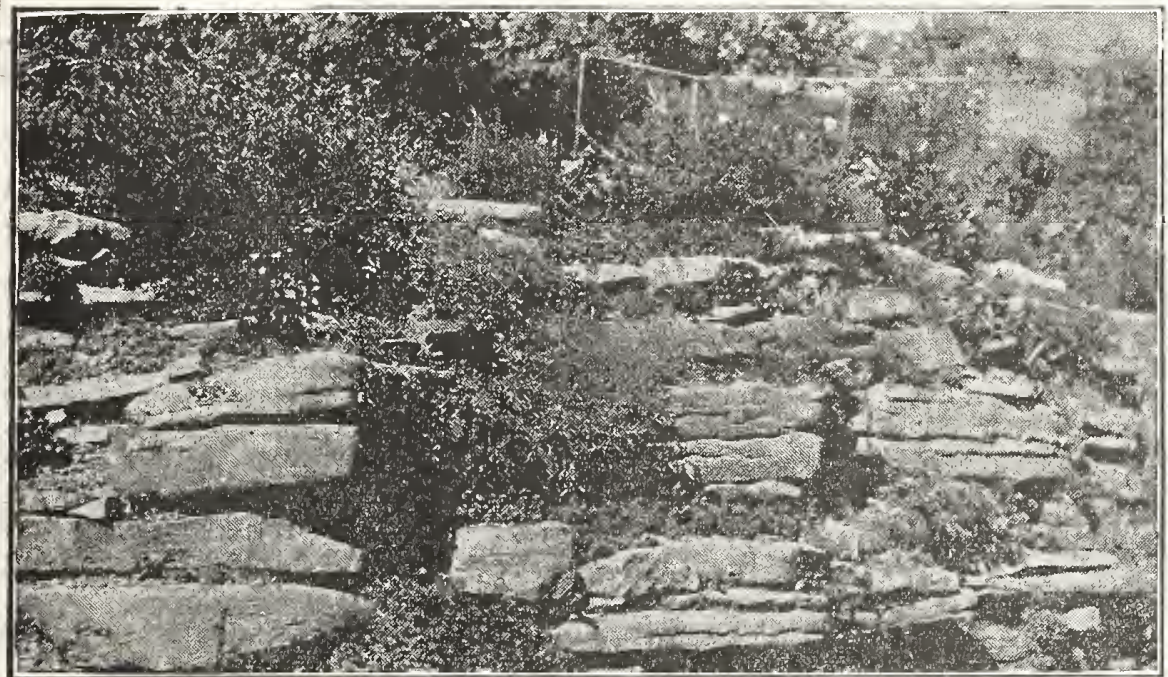

In selecting plants for your Rock Garden, so much depends upon its situation that we hesitate to select a collection for you, much preferring that you select your own with the assistance of the list given below.

\section{TRAILERS NOT MORE THAN FOUR INCHES HIGH}

Alyssum, Saxatile

Arabis, Alpina

Aubrietia (Rock Cress)

Cerastium tomentosum mer)

Mysotis palustris (Forget-me-not)

\section{PLANTS SIX TO TWELVE INCHES HIGH}

Campanula Carpatica

Dwarf Bleeding Heart

Artemisia Pontica (Old Woman)

Platycodon

Linum Perene (Hardy Blue Flax)

PLANTS FROM ONE TO THREE FEET TALL FOR BACKGROUND AMONG THE LARGE ROCKS

Bleeding Heart

Columbine

Hardy Aster, St Egwin

Funkia

Platycodon

Sedum Spectabile

Sedum Spectabilis Brilliant

Yucca

German Iris

Lemon Lily

Full Discription and Price in our Catalog

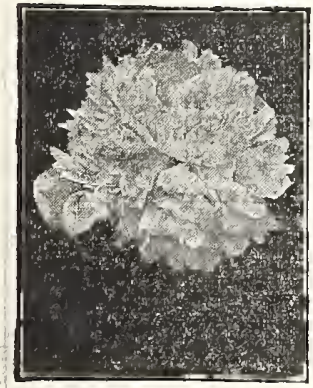

\section{Edulis Superba Peony}

Don't forget, folks, that peonies will do well planted in the spring of the year, although you won't get bloom until the following year. But remember, they must be planted early, while the ground is still cool. If planted in the spring, they should be planted just as soon as you can get the ground in condition. Even if they do not bloom the first year, they will make a nice growth this summer and get their roots firmly established in the ground, and be absolutely sure to bloom the following year. This variety illustrated is the pink one in our cream of the list. See page 84 of the catalog for further description.
Watch Your Roses!

Most of the finest everblooming hybric tea roses are budded on the roots of a sturdy wild rose stock to give them more vitality.

Sometimes in the course of a year or two these wild roots manage to produce a shoot of their own and unless this is promptly cut away under ground at its

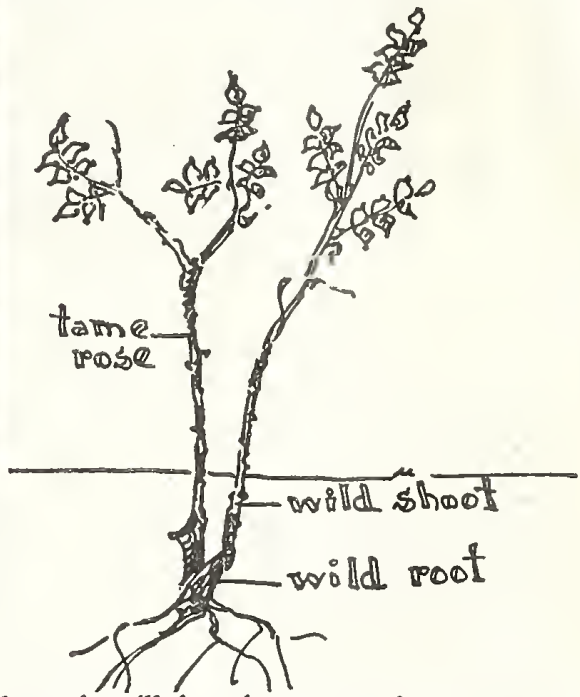

base it will in time smother out the choice but more delicate growing rose that has been budded on.

You can easily detect these unwelcome root shoots by the fact that their leaves normally have seven divisions and their stems are covered with countless small prickley thorns while the hybrid teas have but five leaf divisions and have large thorns widely separated.

If your rose blooms the first year but in the following years runs to lusty foliage and no flowers, take a look at the leaves and stems.

\section{A Beautiful Lily Pool}

Have you written in for our special leaflet on pools and rock gardens?

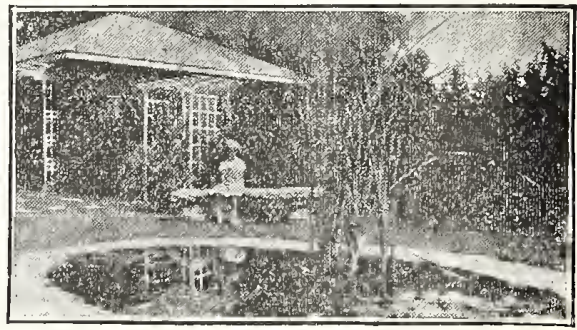

This is a corner of the yard of E. C. Fishbaugh, president of the Security Trust and Savings Bank of Shenandoah. $\mathrm{He}$ and his wife planned their own land. scape and started it only eighteen months before this picture was taken.

They have made our radio vísitors extremely welcome and the little girl is a daughter of Mr. and Mrs. Charles Wil. rich of Earlham, who were in Shenan. doah studying gardens last August. 

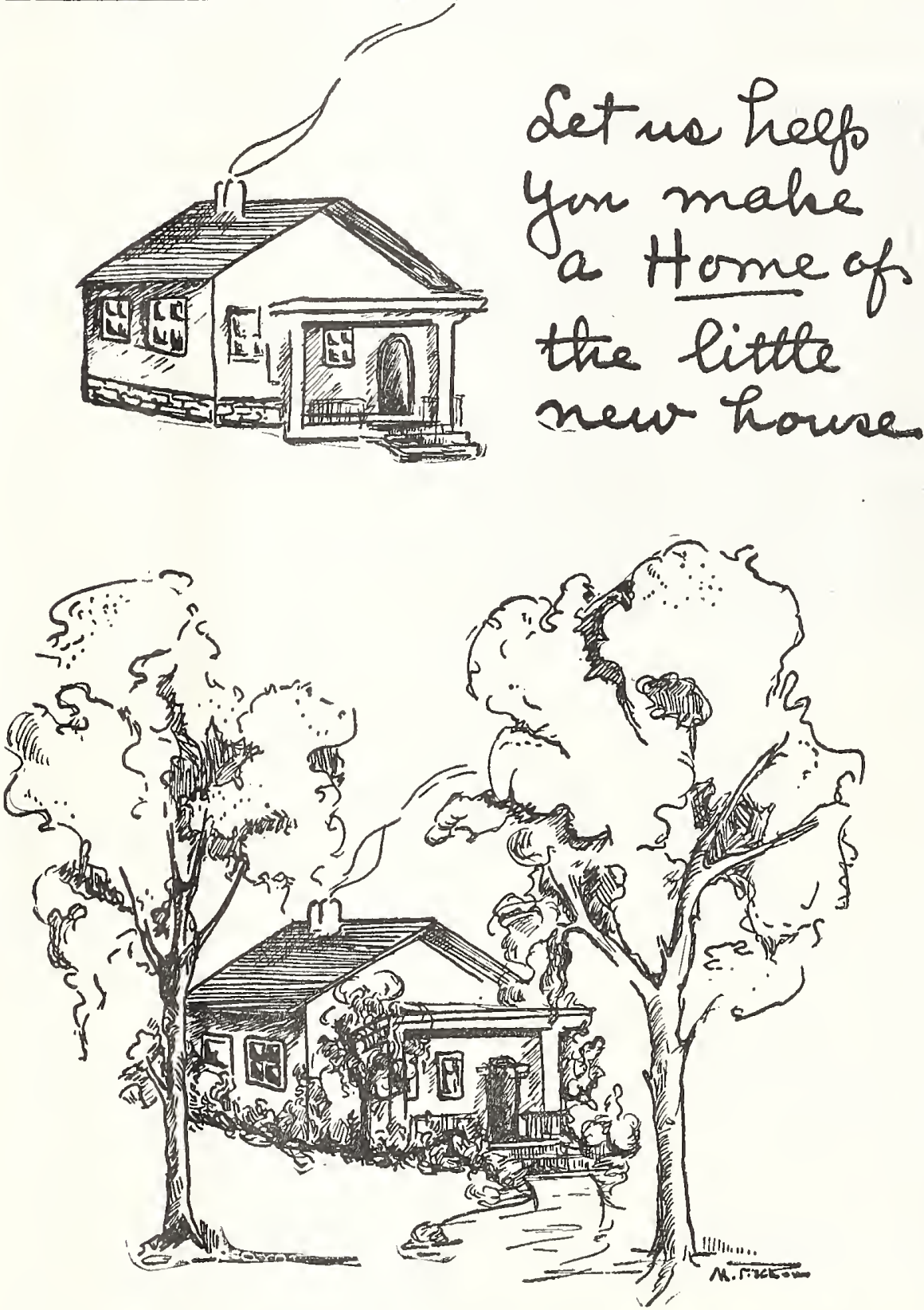

\section{Our Very Best Landscape Offer}

\section{Twenty Shrubs; Three Trees $\$ 5.00$}

Only $\$ 5.00$ spent now will give the is the Tea Rose that is perfectly above effect in a few years if you culti- hardy and never fails to bloom. We vate the shrubs as carefully as you do want everyone to get acquainted with it, your corn and potatoes.

and eventually we think that everyone
will have a bed of a dozen of them. Set

1st. Two Spirea Van Houttei, the well will have a bed of a dozen of them. Set known "Bridal Wreath." One for each these two roses one on either side of the
of the two front corners of the house.
front walk right in front of your BarNo. 2. Six Japanese Barberry. Beauti- berry, which will make a beautiful backful at every season of the year from the ground for them.

time their delicate green foliage starts No. 4. One vine Clematis Paniculata, early in April until their red colorings and This is the hardy vine that has such a bright berries glisten among the snows of mass of fragrant white blooms in Sep. December. Plant three on each side of tember. It will not make much growth the front steps equally balanced. the first year, but by the second year

No. 3. Two of the beautiful Ever- should cover the sunny end of your blooming Rose, Gruss An Teplitz. This porch.

No. 5. For the shady end of your porch use Dutchman's Pipe, which makes a heavy growth of green and does not at all object to shade.

No. 6. Two Bush Honeysuckles. These should be placed at the two rear corners of your house as a sort of a back-ground. They are covered with tiny pink flowers in May and during June and July they will grow to be very tall shrubs and have bright red berries much loved by the birds.

No. 7. Six hardy Hibiscus. Set these along the sunny side of your house between the Spirea Van Houttei and the Bush Honeysuckle. They have beautiful large leaves and flowers like glorified hollyhocks. They are better than hollyhocks for a foundation planting, however, because their bloom continues for many months. These are among the newer subjects for landscape planting and are sure to make a sensation.

They die to the ground every winter but spring up the next year.

These shrubs will make of your house a landscape picture, but we wish to frame the picture and so we will place two Elm trees toward the front of the lot and far enough apart so that they will not crowd the view of the house. The trees we send will be only about two feet tall, but they are full of life and ready to grow four or five feet the first year.

Then just for good measure we are going to add one cherry tree to plant at the rear of the lot to help with the background and with the grocery bill.

Did you ever see a bigger $\$ 5.00$ 's worth? It would be almost $\$ 7.00$ at the regular prices. You know it is what you want, so sit down and make out your order today. Ask the wife what she thinks about it.

And remember this is a prepaid price.

\section{Treasures for the Bird Nook}

Wahoo. A native shrub that grows eventually into a small tree. From its branches hangs charming little fruit something like Bittersweet but is sliades of ruby and crimson, where Bittersweet is scarlet and orange. It is prettier when planted in friendly little clumps of three or four. 75 each; or three for $\$ \mathbf{2 . 0 0}$.

Bittersweet Vines. (The sure to fruit kind). We sell none that have not already fruited in the Nursery. 45 each or two for $85 \dot{t} ; 12$ for $\$ 4.50$.

Rosa Lucida. A dainty bush, wild rose, which bears an unusually heavy crop of red pips, that stay glossy all winter 65 each; two for $\$ 1.15 ; 12$ for $\$ 6.00$.

If you have a large place and want an individual plan for it, write us for details or look at page 83 of our catalog. 
All plants on this page are green growing plants which will be shipped direct from the Greenhouse in another state. Please do not confuse them with the dormant field grown plants of our own growing as listed in the big catalog.

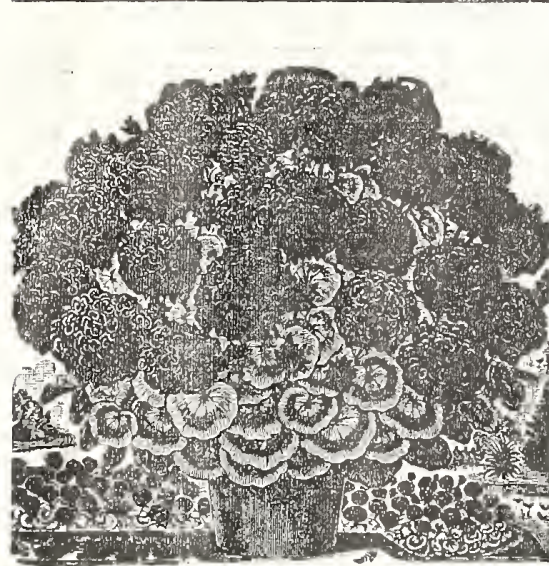

\section{Geraniums}

\section{Mme. Buchner}

A new Geranium of the large flowering type and a fine bedder. Flowers purest white; not a trace of coloring at the center. $26 \mathrm{c}$ ea.; 3 for $74 \mathrm{c}$.

Meteor
An exquisite shade of dark satiny crimson $\mathbf{7 4 c}$. maroon with perfect green foliage. Blooms very freely. $32 \mathrm{c}$ ea.; 3 for $90 \mathrm{c}$.

\section{Peach Blossom}

An attractive shade of silver-ro'se pink, shading white to center. Blooms extra large, very double 30 c ea.; 3 for $85 c$.

A strikingly beautiful shade of deep cerise-tinted violet, with large blotches of 'white at base of petals. Foliage perfect. 32c ea.; 3 for $90 \mathrm{c}$. Radio Red

The finest and most beautiful red Geranium of fered in many yiears. Produces a wealth of bright, dazzling scarlet blooms. $30 \phi$ ea.; 3 for $85 \phi$.

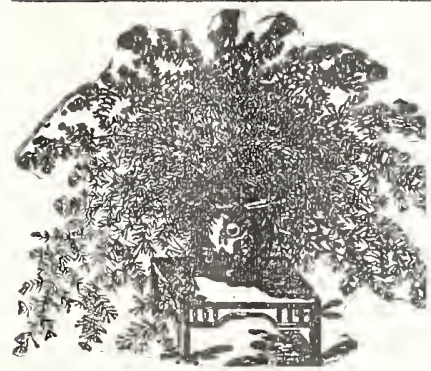

Asparagus Sprengerit

Tall climbing, decorative plant of rarest and delicate beauty. Bright green foliage; extremely fine and plumelike. May be grown as a pot plant, a bushy plant or climbing. $28 \mathrm{c}$ ea.; 3 for $80 \mathrm{c}$; $48 \mathrm{c}$ ea.

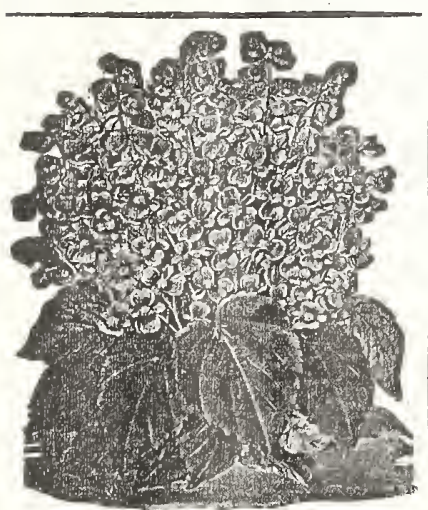

Hardy Begonia Evansiana

This plant is of more than ordinary value. It is a rapid, healthy grower, very profuse bloomer, with beautiful foliage. The plants produce clusters of flowers and buds of a beautiful pink color by the hundreds. The queen of all Begonias. $44 \mathrm{c}$ ea.; 3 for $\$ 1.26$.

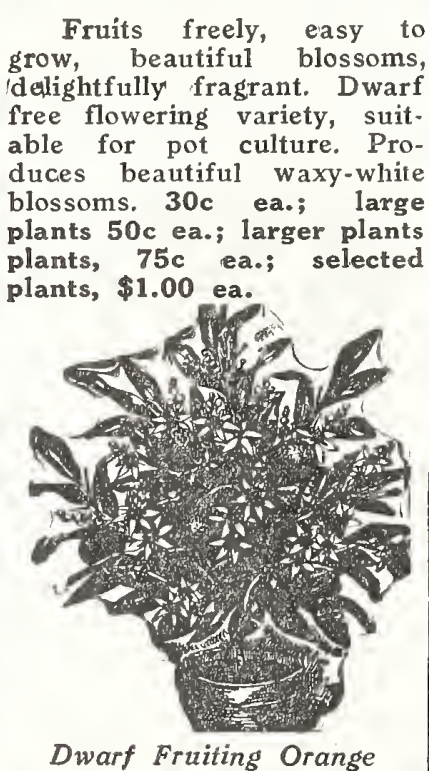

\section{Dwarf Fruiting Orang}

It forms a lovely rosette of its curious shining green leaves, and throws up spikes of the most exquisite lilac rose flowers imaginable. 30 cea.; 3 for $85 c$.

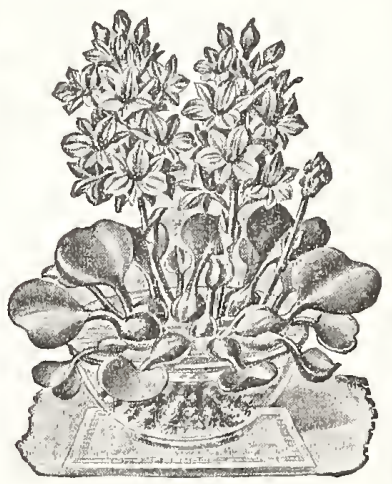

Water Hyacinth

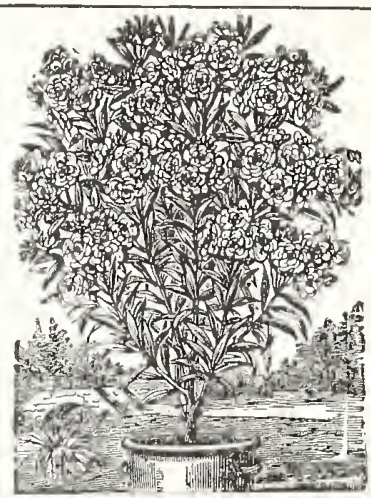

Pink Oleander

An old favorite; flowers pink, double and sweet. 32 c ea.; 3 for 90 c.

White Oleander

Double, white flowers very popular. 32c ea.; 3 for $90 \mathrm{c}$.

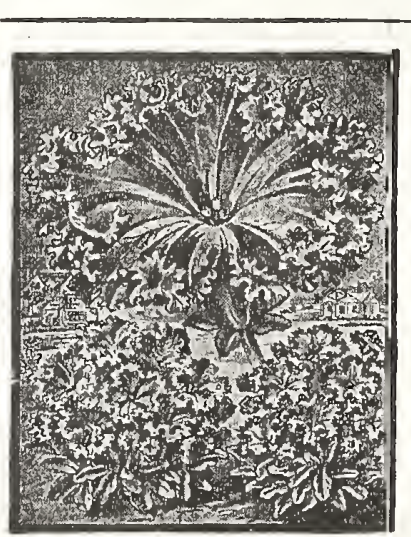

Single Petunias

Uusurpassed for massing. in beds and border planting. Bloom early and continue until nipped by the frost. Mixed colors, 20c ea.; 3 for 57c.

\section{Geraniums}

\section{Argosa}

Beautiful shade of shrimp pink, gradually shading to white. Considered one of the best double bedders. 26c ea.; 3 for

\section{Francis Willard}

Color a light satiny rosepink, flowers large and of per. fect form. 28c ea.; 3 for 80c.

\section{Chrysanthemum}

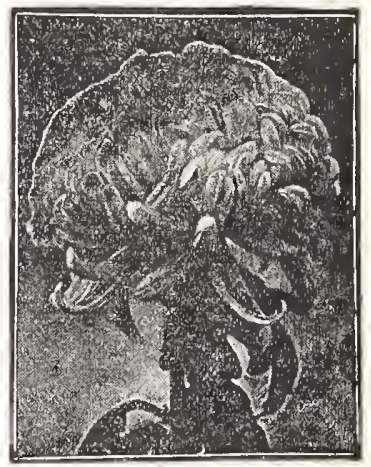

Pink Ostrich Plume

Beautiful rich pink; very showy. $32 \mathrm{c}$ rea.; 3 for $90 \mathrm{c}$.

\section{Fromont}

Extra large flower of marvelous red coloring. $38 \mathrm{c}$ ea.;3 for $\$ 1.08$.

L'Infant Des Mondes

Pure white, strong grower. 32 ca.; 3 for 90 c.

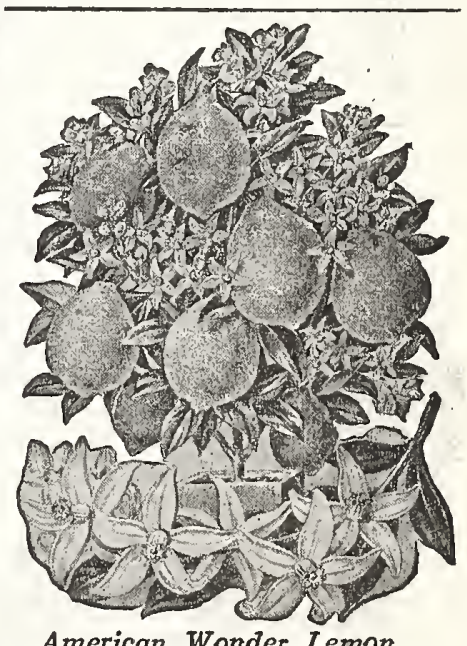

American Wonder Lemon

A true everbearing Lemon. Of very easy culture, flowering and fruiting in ordinary soil. Flowers are fragrant as orange blossoms, which they greatly re. semble. 32c ea.; 3 for 90c; larger plants $75 \mathrm{c}$ and $\$ 1.50$ ea. 
All plants on this page are green growing plants which will be shipped direct from the Greenhouse in another state. Please do not confuse them with the dormant field grown plants of our own growing as listed in the big catalog.

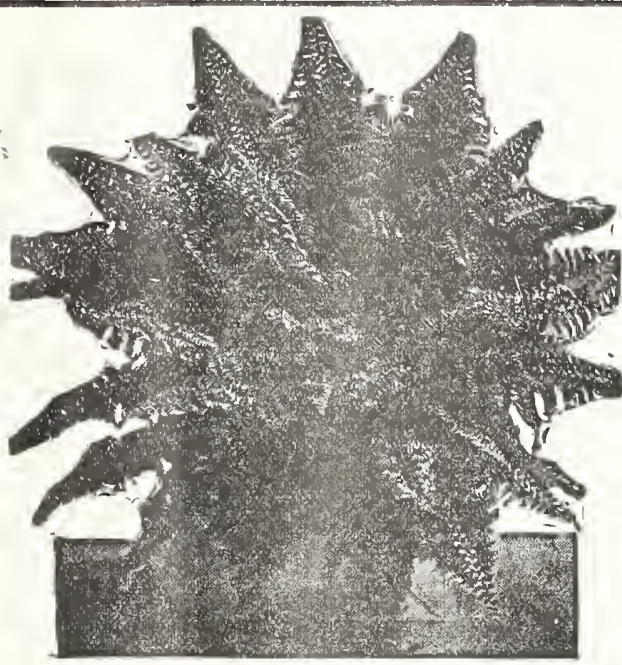
in growing. Each frond is delicately and finely cut, possessing such elegance of form and willowy grace as to be compared to a beautiful ostrich plume. $38 \mathrm{c}$ ea.; 3 for $\$ 1.08$; larger sizes $75 c$ and $\$ 1.00$ ea.

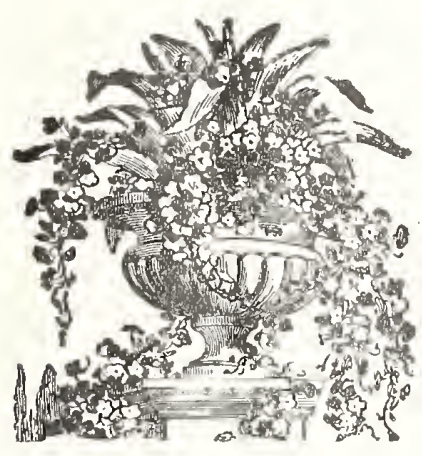

Vase or Porch Box Collection

10 plants, all different, such as Salvias, Dracena, Wandering Jew, Ostrich Fern, Boston Fern, Vinca, Coleus, Petunias, Begonias, Geraniums, Cannas, Hibiscus, etc. $\$ 2.00$.

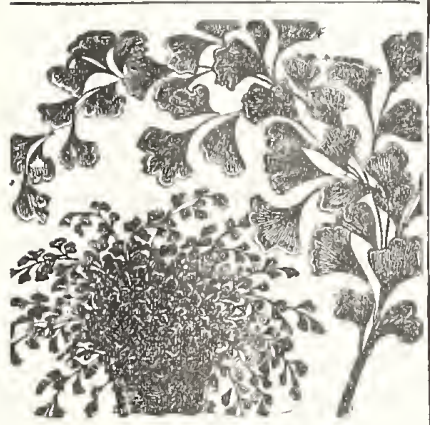

Maiden Hair Fern

An exceedingly beautiful and healthy dark green, feapopular. $30 \phi$ ea., 3 for $85 \%$. 50 r ea., 3 for $\$ 1.43$. thery house plant that is very
No single decorative plant has ever proven more popular. Considered the most valuable house plant to be had. Of easy culture a very rapid grower, producing fronds frequently measuring six to eight feet in length. $26 c$ ea.; 3 for $74 c$; larger sizes $50 c, 75 c$ and $\$ 1.00$ ea.

Fluffy Ruffles Fern

Dark green foliage, darker than any other fern. Dense, compact growth. Its irregular shaped fronds which give it the name of "Fluffy Ruffles Fern" are so formed as to resemble miniature ferns, giving it the appearance of a fern within a fern. 60 ea.; 3 for $\$ 1.70$; larger size $\$ 1.00$ each.

\section{Ostrich Plume Fern}

One of the few feathery foliage (1)

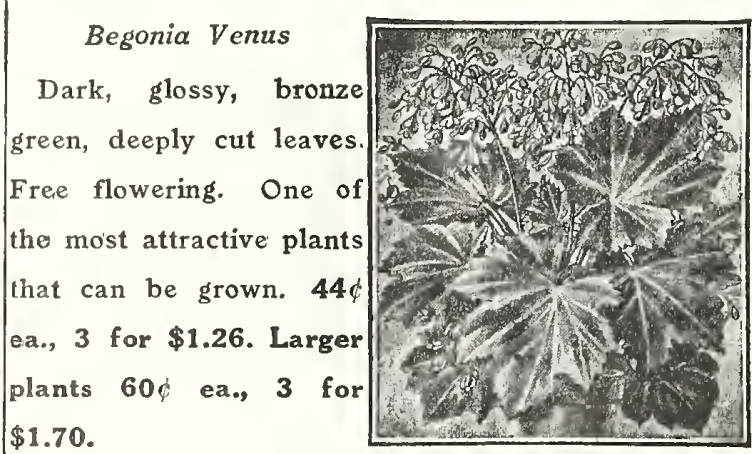
$\$ 1.70$.

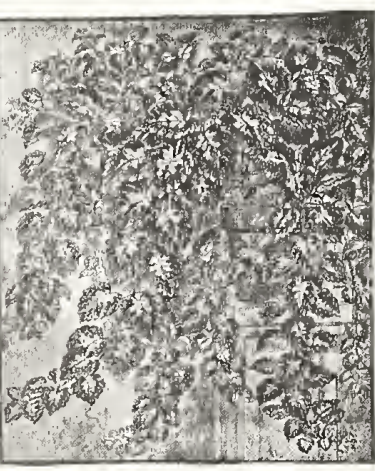

Trailing Queen Coleus

Excellent variety for hanging baskets, vases and plant boxes. Center of leaves fiery crimson surrounded with deep maroon; deeply serrated edges of bright olivegreen. $22 \phi$ ea., 3 for $63 \phi$. ferns which every one can succeed

Decorative plant, striking in foliage no other plant stands as much downright neglect and hardship. Striped foliage $36 \phi$ ea.; 3 for $\$ 1.03$ larger plants 75 ea.; 3 for $\$ 2.14$.

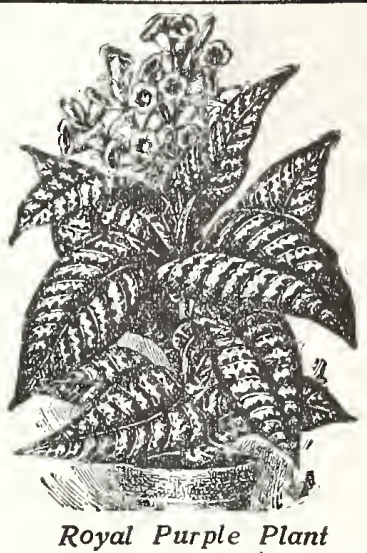

(Strobilanthes Dyeranus) Purple foliage. Universally popular on account of its brilliant and exquisite coloring. Surpasses the finest Coleus, or Begonia in coloring. 28 ea., 3 for $80 \%$.

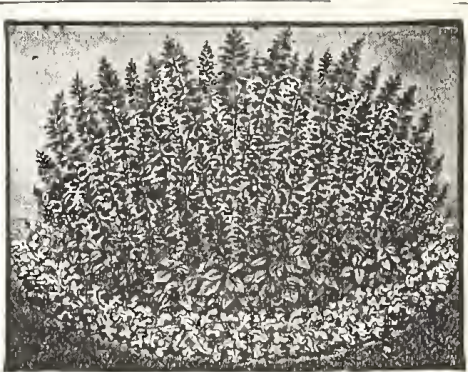

Salvias

They grow in bush form, 2 to $2 \frac{1}{2}$ fieet high. The foliage is dense, forming a mound of vivid green, surmounted by blazing red flowers. $20 \phi$ each, 3 for $\mathbf{5 7} \phi$, $\$ 1.92$ per dozen. 


\section{Alfalfa}

Get started with it, The Queen of all pasture and hay crops. There isn't an animal on the farm that wont make good use of it. This is particularly true of
Don't Buy Your Protein

\section{Grow It}

In Addition

to the high protein feed it produces, Alfalfa improves the soil and diversifies the crops. Keeps The Money on The Farm contains two of the most important vitamines. This, of course, makes it a very valuable home grown supplement for all kinds of stock.

Feeding tests show that soy bean plants have about the same feeding value as alfalfa and you can use it for hay, pasture, silage or for soil building. The seed also makes a very good protein supplement. They are fed with profit to both dairy and beef cattle, hogs, sheep and poultry. You will be better off if you substitute part of your oat acreage for soy beans, as this will make you a home grown high protein feed. They also make a very fine catch crop for hay if you fail to get a good stand of clover, as they can bee planted up until July 1st and still make a good hay crop, if they get plenty of moisture.

Soy Beans are well suited to the

hogs, and the hog raisers are fast learning that they cannot grow hogs profitably without alfalfa for them every day in the year. There is no argument but what One very distinct advantage in growing alfalfa is the finest summer pasture for soy beans is that you can grow them on hogs grown. Brood sows wintered on al-quite an acid soil on which the clovers falfa will be in perfect condition to far-will not grow. They are also more drouth row large litters of strong pigs. Alfalfa resistant than either corn or cow peas will replace from $2-3$ to $3-4$ of the grain and do better on thin or poor land. Beand the hogs will be better for it. The cause they can be grown on acid soils dairymen know that alfalfa is the most they are becoming recognized as an es universally desired and highly prized sential crop in corn belt rotations.

feed of all, equal in feeding value to of alfalfa, either green or dry. Instead as well pulverized as for clover and al. of buying expensive meat scraps, grow falfa. In other words, prepare it about and feed alfalfa which takes its place. the same as for corn. It is best not to
Alfalfa is no more difficult to grow than plant until the ground is thoroughly clover and is more hardy when once es- warmed up or about corn planting time or tablished. Will adapt itself to all kinds a few days later. If they are tended and conditions of soil and climate. Will right, you can raise more beans, either produce two or three times here in the for hay or grain, by drilling like small
cornbelt, and is your cheapest source of grain. The best rate of seeding is from protein. It can be seeded in the spring one to two bushels per acre, using the or in the fall, if you didn't get around to large oat sprouts of the drill. They can fall. We seli as much alfalfa for July, inches apart, especially when growing for August and September seedings as we seed.

do in the spring months. Alfalfa is grown in many different localities, but all varities are not suited to your conditions Buy your alfalfa from a reliable firm that is big enough to purchase alfalfa from all the producing sections, and buy the crop; less fertility is removed from seed of known origin. All of our seed the soil and the practice helps to keep has been thorous the hogs healthy and thrifty due to more sow a very high germination and purity test. sanitary quarters. Hogs harvesting soy planting has been done. Use from 30 to Our 35 years experience in the seed beans and corn will produce more pork 40 lbs. of seed per acre. In extremely business insures you of the best that can per acre, make more rapid gains and re- dry country it should always be drilled be had in the field seed line. We carry quire less feed per 100 pounds of gain in rows and cultivated so as to conserve a full line of the different varieties of than when feeding corn alone. There the moisture.

alfalfa and you will find the prices on should be five beans per hill or drilled the field seed price list. Be sure to in. with the corn at the rate or about 6 oculate your alfais, for it is crop in-pounds per acre.

surance. Enough inoculation to treat a Soy beans and Sudan grass mixture bushel of seed will cost you \$1.00. The makes a lot of forage, high in protein farmers are fast realizing the value of content as well as solving the weed probinoculation, in getting a stand of alfalfa. lem. Drill in 25 pounds of soy beans, Soy Beans Sudan grass.

Inoculate, - it is really crop assurance The soy bean is now one of the and costs only 50c per bushel for soy The soy bean is now one of the and
legume crops of the corn belt. beans. leading legume crops of the corn I believe that next to alfalfa, soy beans Soy beans are now one of the leading are the best all around legume crop for corn belt crops and are very profitable If you want to get in on choice seed at all purposes that you can grow as it has for most any purpose that you wish to lower prices, it would be best for you to more uses than any other crop of this grow them for. So why not grow morelorder early as we have fine stocks of all sort. The bean is one-third protein and soy beans on your farm?

\section{Sudan Grass}

The popular new hay and pasture plant. This is undoubtedly the greates. new crop since the introduction of alfalfa, better quality and with more absolute except alfalfa, and it has the advantase ver alfalfa, of being quick and easy to riend."

It does best on well drained, rich to sandy loam but inasmuch as it sends well an extensive root system, does very good in a dry season when everything else fails, and will feed a team and cor to every acre. We usually figure, as pasture proposition, that Sudan will carr cummer long pounds of live weight al onto a farm, where there is no hay, Sudan is just the thing, for it can be planted in May and you can start cutting in August and again in September. Cut Sudan for as it is starting to head.

Briefly, it is an unusual plant, similar to cane or Kaffir, but much more slender and fine stemmed, easier to cure, quicker to mature, and makes a great yield of

Sudan stools like wheat, and keeps sprouting and can be cut once a month. bundles small and curing in small shocks. The Hay keeps fine, and can be fed the ing value than any other hay except alfalfa. Yields about the same as good alfalfa from 5 to 10 tons per acre, on dry soiling crop, or to put in a silo like corn. advantage of Sudan over other crops is its ability to withstand drought, and make a crop every year in spite of the dry plant millet, and probably cane also, as ither.

The ground on which Sudan is plantIt is very important to get northern grown seed, free from Johnson grass, and free from cane and Kaffir hybrids. Northern grown seed is best for planting either North or South. For prices, see field seed price list.

\section{Clover Prices}

Prices on Alsike, Mammoth Red and Medium Red clover will be much higher by seeding time. Choice seed of any of these on hand now. 


\section{Sweet Clover}

Sweet clover fits well into a rotation. It improves the soil; it supplies abundant pasture; it makes fine hay; fine bee pasture and besides all this, it furnishes a cash seed crop.

Four things are very necessary for success with sweet clover. These are lime, a good firm seed bed, inoculation known as the greatest soil improving crop grown as well as ranking almost as good for hay and pasture as alfalfa. When cut and tended correctly, it is as palatable and high in feeding value as alfalfa hay. It also makes a wonderful pasture, high in feeding value for horses, sheep and dairy or beef cattle.

Shenandoat, lowa. bed being too loose than too firm on cultivated land. Sweet clover requires a firm seed bed with just enough loose plowing up sweet clover. I plowed up a soil on top to cover the seed. More field last week. Got through Friday, failures with sweet clover can be traced the $24 t h$.

to lack of lime than to any other one 1 plowed up 7 acres last year, cause. Of course, it is quite a job to about May 1st. was a heavy growth about lime the ground, but it is necessary to one foot tall._-It yielded 20 bushels per have success with sweet clover or alfal-acre more than the corn right beside it.
$\mathrm{fa}$ and I think it is well worth the trouble I put it in with a loose ground lister. It and expense, if your soil is acid.

looked pretty tough when I got through

Always inoculate the seed. It is very plowing it. I sowed 12 acres this year inexpensive and really is crop assur- to plow up in the spring of 1926.

ance. For best results, always use scarified seed. By that, I mean, seed that has been treated so that the hard coating of the seed has been cracked or scratched, which makes the seed germinate surely and uniformly.

I consider sweet clover the best soil Henry Field Seed Co., improver of any legume. It will build up Shenandoah, Iowa. that worn out farm of yours quicker and Dear Sir:soil improvement, I like the white biennial b.est. It makes an enormous root noon, growth and punches your soil chuck full heard you inquiring about plowing sweet of manure, and loosens up the sub-soil clover Will say $I$ seeded a piece of land wonderfully. Most farmers like to use last fall and intend to let it stand until sweet clover as a catch crop in between in May. Want to turn it under from the their small grain crop and corn. Seed 6th to the 10th. Five years ago, I bought sweet clover in your winter wheat real 160 acres of run down land. Had a early in the spring, or plant it with your fine crop of cockleburrs. I sowcd 60 oats at oat seeding time. When sweet acres of oats and sweet clover. (Sweet clover is seeded with oats, be sure and clover seed was $\$ 23.00$ and $\$ 24.00$ per not' get it in too deep,-one inch deep is bushel.) I turned under 40 acres the plenty and one-half inch is better. After next spring and raised 60 bushels of seeding, firm the seed bed in some way corn to the acre. I have winipped the by running over it once or twice with a burrs and built up my land. I know roller or culti-packer. After the small sweet clover can be plowed up late.

grain has been taken off, with a fair enough amount of lime in your soil, you will have a growth of 18 to 20 inches, which you can cut for hay or pasture down, equal in feeding value to alfalfa. Don't plow your clover under in the fall, but let it grow as late as possible in the spring and follow with corn. Plow 8 or 9 inches deep and disc and harrow a few times. When handled in this manner, you are putting enough nitrogen in the of oats, one bushel of Canadian Field soil for 100 bushels of corn per acre. peas and 3 or 4 pounds of Dwarf Essex When a good stand of sweet clover is rape per acre. This mixture will carry a plowed under it will return fertility to large amount of stock per acre and is an your soil equal to 20 tons of farmyard excellent feed high in feeding value. manure per acre. Instead of raising 30 bushels of corn per acre, you can raise 70 oats and then to 80 bushels per acre. What more can not to get it in too deeply.

\section{Rape}

Grow more rape, an ideal hog pas. ture, almost equal to alfalfa. If you are short of hog pasture you will be pleased with rape, as it makes a very valuable pasture. One acre of rape will pasture 3 months. Last year it was used by a large number of ton-litter producers and 20 hogs with the grain they receive for without exception it was pronounced an unusually good hog pasture crop. In past uring, let the rape keep ahead of the pigs, in other words do not pasture too close, it is a good plan to alternate your pasture, let one recuperate while the other is pastured. It is also a good plan corn that is allowed.

Rape seed is cheap this year, and you should sow from 8 to 10 pounds per acre, on a well prepared seed bed, and cover about $1 / 2$ inch deep. Rape can also be seeded in the corn at the last cultiva. tion, and is the most valuable pasture crop that can be seeded in the corn. The seed may be sown with a hand seeder immediately preceeding the last cultivation or it can be drilled in with a one horse drill. Rape should be an important part of the crop programs on all farms that carry livestock, particularly hogs, sheep and calves.

\section{Small Grains}

Yes we will have Oderbrucker Barley which is a bearded variety 6 rowed and best yielder here in the corn belt. Use 2 bu. of seed per acre.

Spring wheat, yes we will have the Marquis variety which wie like the best for this section. It is a beardless variety, stands up well, is very early, with good milling qualities.

\section{Cyclone Broadcast Seed}

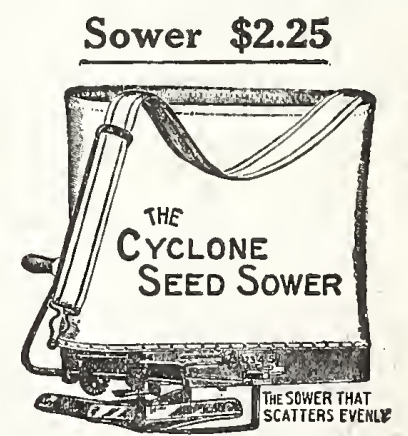

This is the best Seeder made at any price. It is roomy, strong, works evenly, and will sow any kind of seed any de. sired thickness. It is fully guaranteed and if not perfectly satisfactory may' be returned at our expense. Price \$2.25 f. o. b. here. If wanted by parcel post, add postage for 5 pounds. 


\section{Smoked Salt, the Modern Method of Meat Curing}

One of the biggest iniprovements in meat curing in recent years is Smoked Salt, which enables you to salt and smoke your meat all in one operation.

We have been using and selling Old Hickory Smoked Salt for the past two years and can recommend it most highly as it is absolutely satisfactory in every way. We sold nearly two carloads of it last Winter and the customers are all very enthusiastic regarding it.

Old Hickory Smoked Salt is simply the best grade of meat salt, put through a thorough smoking with genuine hickory wood smoke.

It is used the same as any other salt in the curing of meat. You can use it in the regular sugar cure. Ycu can use it, in fact, in any way that you would use any other salt in curing meat, using the same amount called for in any good recipe.

The only difference is that when you once get your meat salted it is also smoked, for the smoke enters the meat with the salt and by the time the meat is thoroughly cured with the salt it is also fully impregnated with genuine hickory smoke, better than it would be salted first and then smoked afterwards in the usual manner.

When you salt the meat first and then smoke it afterwards it gets hard and the smoke cannot penetrate the meat, but with the use of Old Hickory Smoked Salt, the smoke penetrates the meat right along with the salt, so you have smoke clear to the bone.

Meat keeps better cured with Old Hickory Smoked Salt, tastes better and is very much less work.

You get rid of the smoke house with all its dirt, labor and fire risk. You save all the time that you would ordinarily take in the smoking process.

All you have to do is to put the meat through the ordinary salt cure, whatever process you use, then wipe it off and hang it up. It is salted and smoked, too, and ready to keep all summer and all Winter if Necessary.

It saves the cost of building a smoke house and all the work of smoking. The smoke flavor does not dry out of the hams and bacon and make the drippings too strong for other cooking. The flavor is unsurpassed. No noticable shrinkage of meat by using this process. By using the directions furnished nobody can fail to get good results.

This Old Hickory Smoked Salt is not at all expensive. It sells at $\$ 1.25$ for a 10 -pound carton, which is sufficient to treat 125 pounds of meat. Prices include delivery by express or parcel post.

It can be bought in most grocery stores, but if they do not have it, send to us and we can send it to you from here. The price is the same wherever you get it, $\$ 1.25$ per carton of 10 pounds. follow.

Full directions come with the salt, which are simple enough that anyone can

FREE MEAT CURING BOOKLET AND SAMPLES

The smoked salt people send out the best book on meat curing that I have ever read. It gives a number of splendid recipes for cutting meat. Gives full instructions about buttering and everything along that line. It is a book worth having and will be sent absolutely free of charge. If you are interested in home curing of meat, write for this book and it will be sent to you along with sample of Smoked Salt.

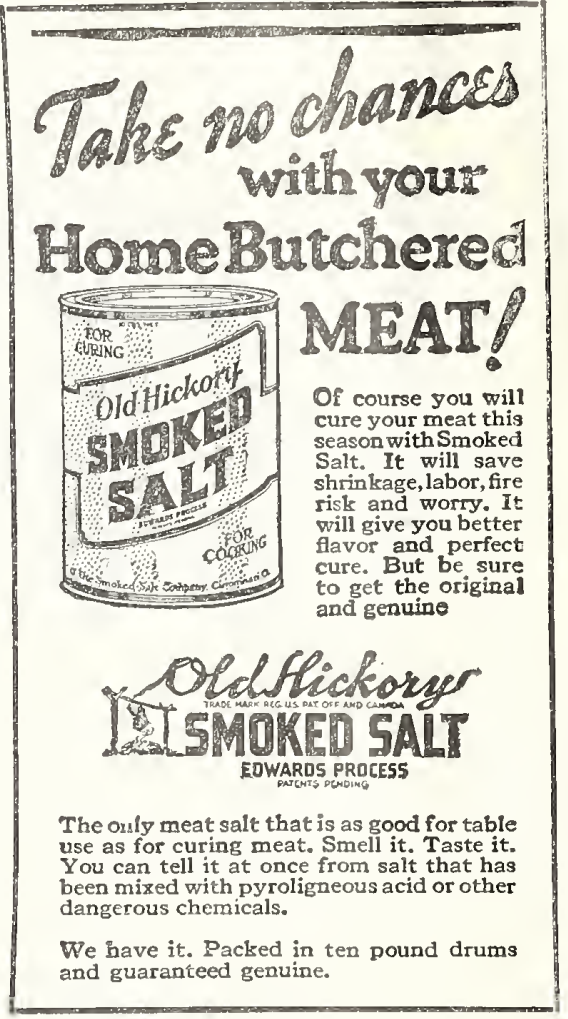

SEND YOUR ORDERS TO US

Send your order for Smoked Salt to us. We have a carload of it on hand here at all times in the meat curing season and can give you prompt shipment. We can furnish you any quantity you want, but remember it comes only in 10 -pound sealed cartons so don't order odd amounts.

\section{McQueen's Inoculator}

\section{BE SURE TO INOCULATE ALL LEGUMES}

McQueen's Inoculator insures a good stand, increased yields, hastens maturity, puts a nitrogen factory right on your farm.

The farmers are rapidly learning the value of inoculation as a means of securing a good stand of leguminous crops, such as alfalfa, all clovers, peas and beans, in fact, inoculate all pod bearing plants. Inoculation gives the roots of your plants the power of taking nilrogen from the air and storing it in the soil to be used by future crops. A good inoculated legume crop will store 100 pounds of nitrogen in your soil per acre.

We have been experimenting for several years with inoculation and have chosen McQueen's Inoculator as being the best, because the bacteria in McQueen's are raised under actual field conditions, by a real dir f̂rmer. They are also bred and reared under adverse conditions so that they will be able to survive your field conditions. This inoculation doesn't cost much, you can buy a bushel size can for $\$ 1.00$ which is enough to treat 60 pounds of alfalfa or clover and will treat 100 pounds of the larger seeded legumes like peas or beans. Folks, you can not afford to plant any legume without inoculating it, so "For The Land's Sake" use McQueen's Inocu- lator. Very easy to apply, full directions on each can, and when ordering inoculation, be sure to tell us what legume you are going to treat as there is a different kind of bacteria for each one.

The guarantee with McQueen's Inoculator is as follows: Use as many packages as you wish, according to directions, and if nodules do not appear on the roots of your plants in a satisfactory manner, we will refund the entire purchase price. That is the strongest guarantee $I$ ever heard of but McQueen says it is $O . K$., so' we are selling inoculation fully guaranteed.

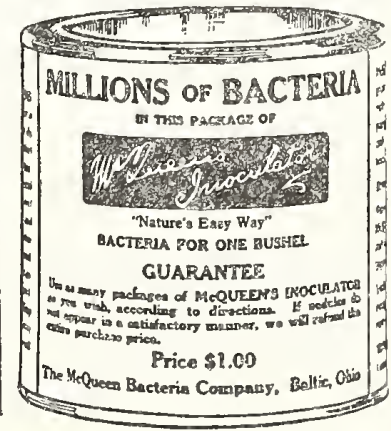

\section{POSTPAID PRICES}

1 Bushel size - B...-_-_\$0.50

1 bushel size 1.00

6 bushel size 5.00

10 bushel size 7.50

Garden size (combination) $\mathbf{2 0}$ Inoculation for Soy Beans, Cow Peas, Vetch and all large seeded Legumes, 50 per bushel.

( $B e$ sure to name the legume you are going to treat). 


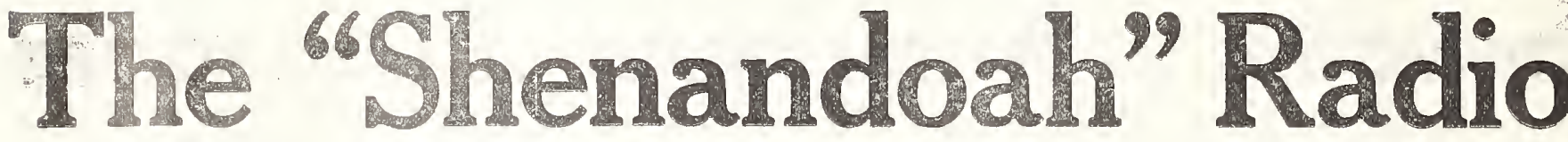

\section{The Shenandoah Five} Table Mode!

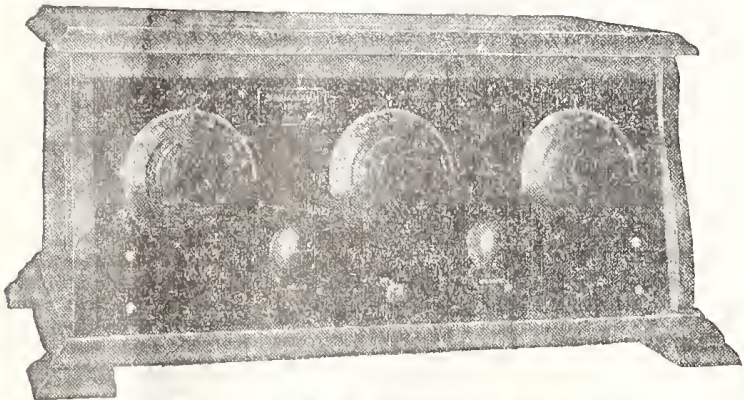

\section{THE SHENANDOAH FIVE}

\section{Complete With Equipment as Follows}

A-Battery 100 Amp.

$\$ 12.00$

Speaker 15 in. Cone

9.00

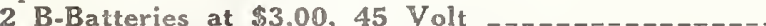

Hydrometer _..........

5 Tubes at $\$ 1.50,201-A$

.60
.60

C-Battery at $60 c, 4 \frac{1}{2}$ Volt

7.50

Aerial and Ground Equipmemt

Set

25.00

Less $\$ 5$ if Complete Equipment is ordered

62.70 TOTAL

$$
\text { F. O. B. Shenandoah }
$$

5.00

57.70

I do not believe there is a 5 tube receiving set on the market that can come up in volume and quality to this one.

The Shemandoah Five can be had for a price that is surprisingly low. Our big volume production makes it possible for us to offer you the fine Shemandoah Five installed in a handsome durable two-toned, solid Philippine Mahogany Cabinet $21 \times 111 / 2 \times 91 / 2$ for only $\$ 25.00$

The set is made of scientifically selected and constructed parts assembled by craftsmen who know radio in all its phases. Each individual part is tested and the entire set is put through a thorough reception test before it is declared fit to be shipped to you.

Loud Speaker. A fine quality speaker that reproduces speeches, orchestras, or any inusical instruments faithfully, with excellent volume and perfect tone. It is a cone speaker 15 inches in diameter, of good quality and one I am sure that will give you good results. If you would rather have a horn let us know as we have them at various prices.

HERE IS WHAT SOME CUSTOMERS SAY

$l$ just want to write and tell you how mucl $I$ an en. joying the five tube Radio set that was purchased from you by our danghter and husband of Hope, Kansas, and we thank you for the prompt shipment. It is giving good satisfaction and we are enjoying the programs from your station very much.

$$
\text { Mr. and Mrs. Ruchty, Baldwin City, Kansas }
$$

\section{HORN SPEAKER $\$ 12.00$}

I.told you a while back I was trying to find a good horn speaker that I could sell reasonable. For $\$ 12.00$ I can send you a mighty fine speaker equal to any $\$ 25.00$ one I ever tried. It is about 2 feet high has 15 inch bell, smooth finish, beautiful tone, and a swan neck style. I selected this speaker after trying about 50 different makes. This horn does not need aेdjustment but is universal adjustment. If wanted instead of Corie Speaker, add $\$ 3.00$ to price of full equipment.

\section{The Shenandoah Super-Six}

\section{Table Model}

The Shenandoah Super-Six is a wonderful six tube set witl up to date circuit, has the two dial control, which is really the most practical and best control of any, has wonderful tone, plenty of yolume and selectivity. The Shenandoah Super-Six is in a solid Philippine Mahogany $C$ abinet and makes a very beautiful piece of furniture $21 \times 11 \frac{1}{2} \times 91 / 2$. You can use the same high quality cone speaker as on the Shenandoah Five Tube Receiving Set.

This set, to my notion, is one of the best buys in Radio Land today, as it is a six tube set, easy to tune, and throws out a wonderful tone and that is what the people want today.

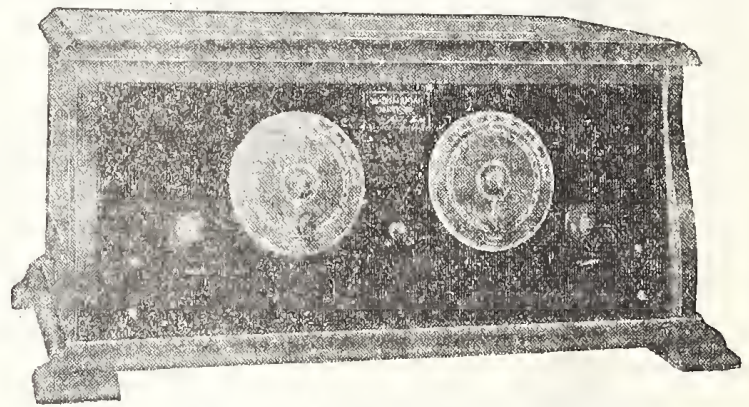

\section{THE SHENANDOAH SUPER-SIX Complete With Equipment as Follows}

A.Bartery, 100 Anp.

$\$ 12.00$

Speaker, 15 in. Cone

9.00

2 C-Batteries ot $60 \mathrm{c}, 41 / 2$ Volt $\ldots \ldots \ldots \ldots \ldots$

9.00

6 Tubes at $\$ 1.50,201-A$

1.20

Aerial and Ground Equipment _............

9.00

Hydrometer

2.00
60

Less $\$ 5$ if complete equipment is ordered

40.00

82.80

TOTAL

5.00

77.80

\section{F. O. B. Shenandoah}

\section{CONE SPEAKER}

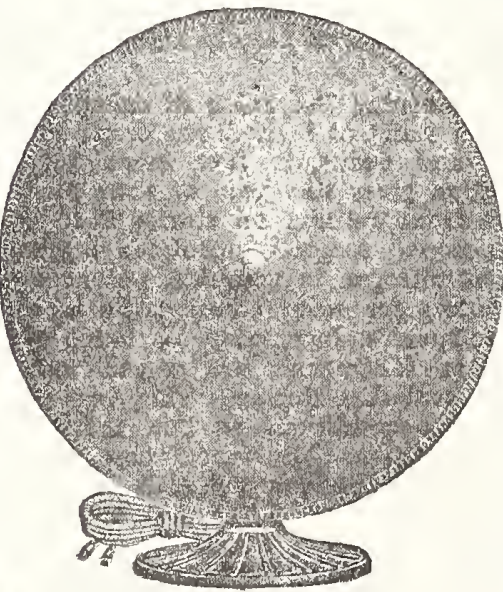

Cone Speakers are be. coming very popular with many radio listeners, and we have one to offer you at a very low price that is equal to many selling for three times as much. Made of specially treated parchment, which throws out its tone uniformly in all directions. It is very sensitive and capable of handling great volume. Will re-produce speeches orchestras or any musical instruments with excellent volume and perfect tone. This cone is 15 inches in diameter and sells for $\$ 9.00$.

Accessories are all f, o. b. Shenandoah, Iowa 


\section{Special Winter Price Reductions}

\section{The Shenandoah Super Six}

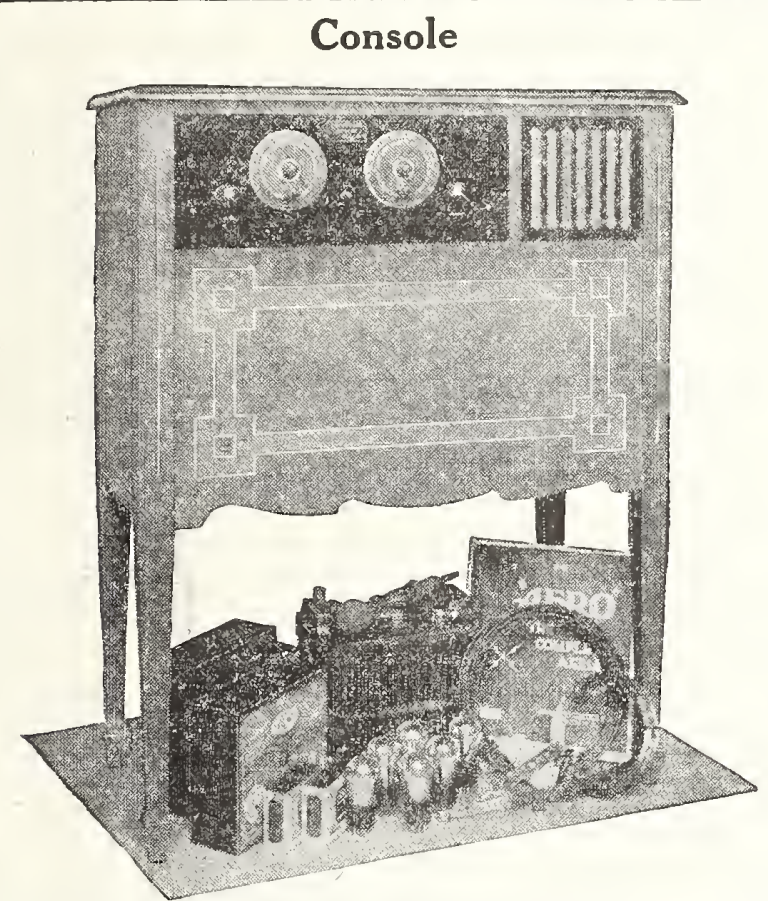

Here is the extremely selective and luxurious console, no set is tuned easier. It is the same as the regular table model 6 tube set, built in a beautiful console cabinet, size $30 \times 15 \times 381 / 2$. It has its own built in Speaker.

\section{The Shenandoah Super-Six Console Complete With Equipment as Follows}

A-Battery, 100 amp.

3 B-Batteries at $\$ 3.00,45$ volt

2 C-Batteries at $.60,41 / 2$ Volt

6 Tubes at $\$ 1.50,201-\mathrm{A}$

Aerial and Ground Equipment

Hydrometer

Set

Less $\$ 5$ if complete equipment is ordered

\section{TOTAL}

$\$ 12.00$

9.00

1.20

.9 .00

$$
2.00
$$

103.80

5.00

98.80

Compartments for all batteries, tools extra tubes and such things. It is a complete unit in itself and all you will need will be a wire from it to the ground and one to the aerial.

The Shenandoah Super-Six Console has a new up-todate circuit with six tubes, gives a beauty and perfection of tone with volume and distance.

The greatest thrill you will ever experience in radio will come the first time you switch on the beautiful Shenandoah Super-Six Console and pick up station after station, turning from one to the other at will-Listen to them near and farin full concert volume through the built-in Utah Speaker.

The Utah Speaker is a feature itself as it is well known throughout the country and is wonderful in tone and quality

Auxvasse, Mo

We received the Super-Six in fine condition without a scratch. It sure is a fine set and works as fine as it looks. We have had stations all over the U. S., even California. It has a fine natural tone. and more volume than we can use. What more could any one want.

\section{Radio and auto Storage}

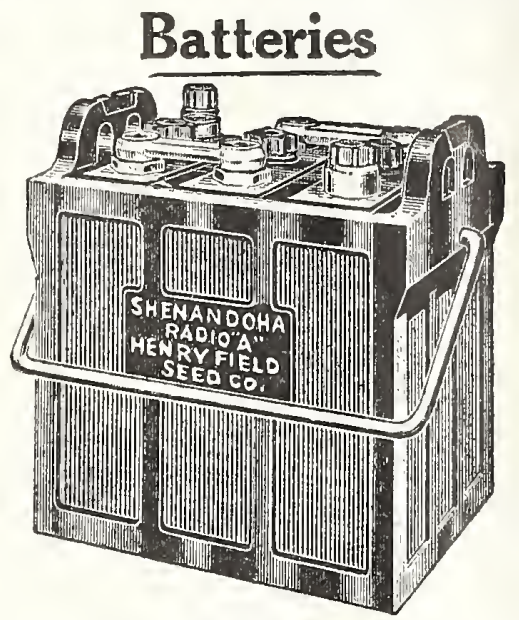

A good storage battery is the life of your radio. Our "A" batteries are made according to our own specifications and carry our own name and brand. They are carefully made from the best of materials, and are full weight and capacity. They are made with both standard and thick, heavy plates, which tend to greatly lengthen the battery life and produce a slow, even and distinct discharge. Rubber composition case and the 100 and $120 \mathrm{amp}$. are equipped with bale handles. Can supply either radio or car batteries at the following prices. 6 Volt -11 Plate 100 ampere hour $\ldots \ldots \ldots \ldots$

6 Volt-13 Plate 120 ampere hour

6 Volt-15 Plate 140 ampere hour

6 Volt-17 Plate 160 ampere hour _.......... \$19.00 12 Volt Dodge Car Battery CHARGE EVERY 10 OR 15 DAYS

\section{"B" BATTERIES, 45 VOLT}

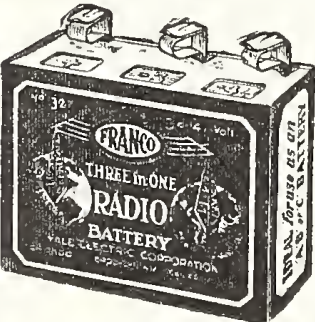

Good "B" batteries are very neces. sary for good radio reception. Our batteries are of a standard make, full size 45 Volt. "B" batteries usually last from 6 to 8 months. One nice thing about ordering batteries from us is that you are sure of getting fresh batteries, for we get them fresh from the factory every few days, Price of our "B" battery $\$ 3.00$. Can also supply a $41 / 2$ Volt "C" battery for $60 \%$.

\section{TUBES}

We use the 201-A tubes with UX base in several different makes. They are all thoroughly tested before they are sent out, and the material used and workmanship is of the highest quality. Don't leave tubes in set while making connections.

Type UX 201-A

Type UV 201-A

Type UX 199

Type UV $199 \ldots$

Type WD $11 \ldots 2.25$

Type WD 12

Type 300-A Special Detector

Type UX 112 power

Add 25 to each order for postage and packiag when less than 5 are ordered. 


\section{Field's "SHENANDOAH" Cords}

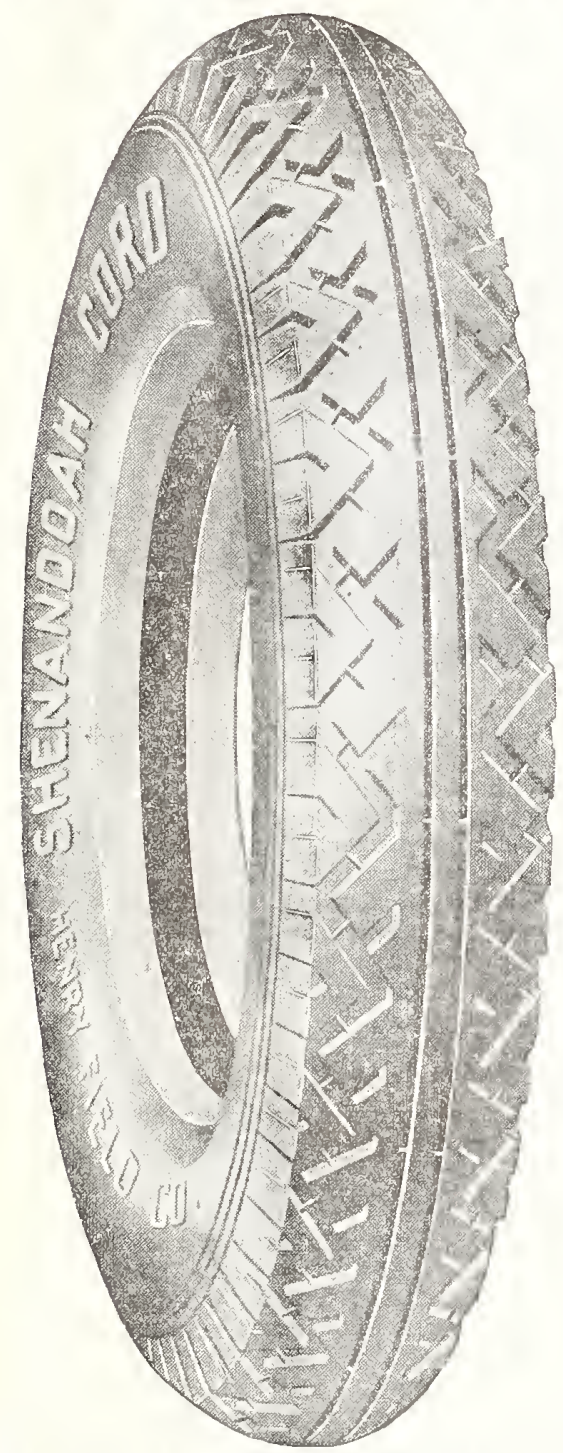

A Word About Tire Selection

Here are some suggestions that I hope will help you select the tire that will give you the best service and riding qualities.

We make two sizes in the $30 \times 31 / 2$ tire, the regular and the oversize. You folks, I am afraid are not giving enough consideration to the weight of the car you are using on various tires for the best service. Much time and thought has been given this subject, and our conclusions are that for the best service, use the $30 \times 3 \frac{1}{2}$ regular on roadsters, touring cars, and front wheels of sedans,

A Ford touring car will weigh around 1,500 pounds and a Ford sedan will weigh around 2,100 pounds, I am sure you folks can readily see that these two cars require different size tires to get the same results. We strongly recommend the $30 \times 31 / 2$ oversize for use on the rear wheels of Ford sedans, for the best service.
This is the most important message we have ever written to our millions of customers, first when you realize that the Henry Field Seed Company did a larger volume of business in the month of December than we did the last six months of the year 1925, you can get some idea of the rapid growth of our institution; I do not believe there is another institution of its kind in the country that can boast of such a tremendous growth, there must be a reason and a good one, and here it is as we see it;

Big Tire companies have always made too large a profit on tires, the tire users were compelled to pay big prices for tires because there was no one to intervene and I might say this, that there has been a very slight drop in the prices of Crude Rubber since we entered the Tire Business and still Tire Prices have been almost cut in two, in fact you can buy a tire now for half what it would have cost you when we entered the tire business.

\section{You Helped Bring These Prices Down}

By sending your orders to the Henry Field Seed Company, NOW HELP US KEEP THEM DOWN

To give you an idea of the tires we are selling, we have mould capacity for $20530 \times 31 / 2$ tires a day, and we have been running behind on orders for this size; of course this is our best selling size but if we were selling all sizes in the same proportion, we would have a daily output of 4,000 tires a day; we do have an output right now of enough tires to keep a fair sized factory busy making Shenandoah Tires and in six months if we keep up the increase we have had in the last month, it will keep three tire factories busy making Shenandoah Tires.

We are going to save the automobile owners Millions of Dollars in tire upkeep of their cars, because we have the right method of distribution, when you buy a Shenandoah Tire, you are getting as good a tire as can be made at the lowest possible cost to you; To give you an idea of the method we use in handling our tire business, we contract with a tire factory to make tires for us in our moulds, and we agree to pay them the cost of manufacture plus a 10 percent profit to them, then we add on a very small profit for handling the tires direct to you and that is all that is added to the original cost of the tire, our overhead expense is very small here in Shenandoah compared to what it is in the larger cities and we are therefore enabled to sell you the very best tire made at the cheapest price ever quoted on a quality tire.

\section{Shenandoah Cord Tires Are First Grade Tires}

We do not carry a secondary line of tires, we could sell you the tires at a very muchly reduced price if we cared to cater to that class of trade. but we have always believed in selling only the best in everything we sold and do not care to change our policy when it comes to tires.

Every large tire factory has a second grade tire, sold in something other than their own advertised brand and most dealers are offering them at prices about the same as ours, but if you consider the method of distribution of tires, you can readily see that it is impossible for any company regardless of size to compete with us in price, quality considered.

\section{No Better Tire Can Be Made Than Shenandoah Cords}

By having a daily output of an entire tire factory, it is possible for us to get bids from most of the tire factories in the country to make Shenandoah Tires for us, and if we did not think we were getting the best tire it is possible to make out of Cord Fabric and rubber, we would certainly change and get our tires made where we did think they made the best tires. We have tried our tires out alongside of most every known brand of tire and they lave given a better demonstration when it comes to service than any tires we have yet encountered; we have thousands of letters from customers telling how Shenandoah Tires are outwearing tires on opposite wheels that cost two times as much.

\section{A Real Non-Skid Feature}

Shenandoah Cords have the best non-skid feature of any tire made, you will say so too; when you see one. Our tire, being a low-pressure cord, gives every time it comes around and lets the soft, pliable rubber skids come clear together absolutely cleaning the non-skids, ready to take another grip the next time it comes around. Many of our customers have told us that they have never been caught in the mud where they had to put on chains, and I think you will agree that this is quite a feature. 


\section{"Shenandoah"Balloon Tires}

All 6 ply except the $29 \times 4.40$

My guarantee for 12,000 miles on Henry Field's Shenandoah Cords completely protects you on the quality of Shenandoah Tires. If the higher priced tires are as good or better than the Shenandoah tire, why don't they put a mileage guarantee of 15,000 or 20,000 miles on them to take up the slack in the difference in the cost? You wouldn't pay 35c for a gallon of gas that would only take you 20 miles if you could buy the same gas at another place for 20c that was guaranteed to take you 20 miles would you? The same thing applies to tires; it's mileage you want and that's what we guarantee, 12,000 miles of it.

\section{WHY 6 PLY BALLOONS?}

Evveryone who has used balloon tires has probably had more than the usual trouble with punctures. Partly because the balloons naturally run soft and partly because they have so large a surface on the ground.

It looked to us like the only remedy was to make the balloons heavier-6 ply. We were making our balloons the same as other No. 1 tires, 4 ply, but we wanted something better-something that wculdn't puncture every time you run over a tack. So about October 1st, we began making all our balloons 6 ply (except the $29 \times 4.40$, which would be too stiff if made 6 ply) and that is the way they are made now, 6 ply.

Very few other makes are made this heavy but we wanted the best, so we did it. And did it without extra charge. We are absorbing the extra cost ourselves without raising the price.

So if you have had trouble with punctures on balloon tires try our 6 ply balloons.

HENRY FIELD

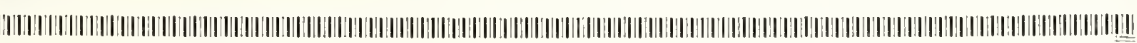

\section{Here Is a Guarantee That Means Something}

Besides quoting you the lowest prices ever quoted on a high quality tire, when you buy a Shenandoah Cord tire you get the strongest guarantee that is possible to give on a tire. We guarantee 12,000 miles of service and we put no time limit on the guarantee, if at any time a defect in material or workmanship should develop we will repair the tire free of charge or replace it with a new one, charging you only with the mileage received. This definite final proof of the quality that is in our Shenandoah Cord Tires.

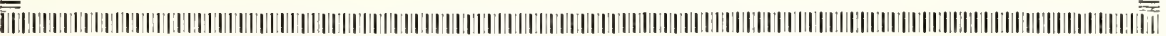

\section{Our Money Back Guarantee Protects You}

If you have never tried a Shenandoah Cord Tire, send us your order, look the tire over and compare it with any tire, on the market, if it does not look like the best tire you ever seen at any price, send it back and we will refund your money; we know what Shenandoah Tires are and that is why we will make you this proposition.

\section{Why We Are Able to Quote These New Low Prices}

Our business has grown so fast that we have hardly been able to get tires fast enough to fill the orders, this enables us to give you a much better price, because the more tires we sell the cheaper we can buy them and the less it costs us to handle them; in fact, you are your own tire dealer when you buy your tires of us, you buy direct, the same as the tire dealer, only you buy them even cheaper, because there is no branch house or jobber to take out a share of the profits, you save it all.

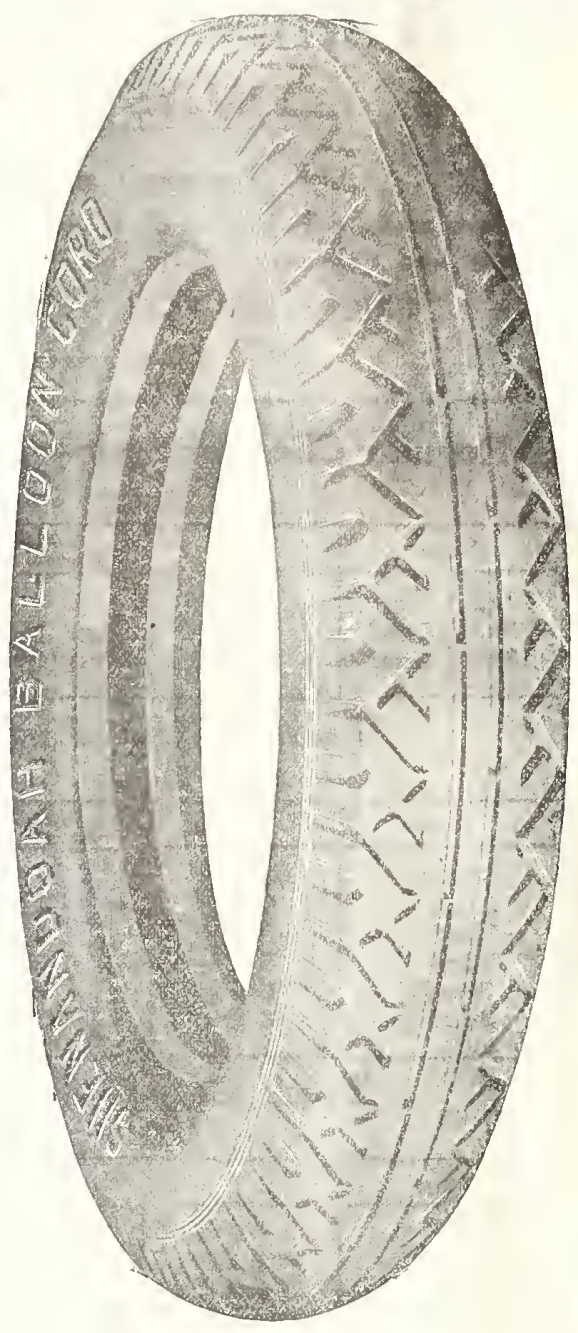

\section{All New Fresh Stock}

Shenandoah Tires are made up and shipped direct to us the same day, right hot out of the moulds, they do not have a chance to lay around in a warehouse or storage for six months or a year before they are shipped to us. You can tell by the feeling of a Shenandoah Cord that the rubber is alive, it is soft and pliable, it does not have time to get hard and brittle before the customer gets it, and that is another reason for the long mileage you will receive from Shenandoah Cord Tires.

\section{Ask Any Tire Dealer These Questions}

How much extra profits are added to the actual cost of your tire after it leaves the factory?

Why has the factory that makes your tire limited the guarantee to 90 days instead of 12,000 miles?

Has your tire a real non-skid feature? If he says it has compare it with the Shenandoah Cord and see for yourself. 


\section{Field's SHENANDOAH Tires and Tubes}

\section{FIELD'S NEW LOW PRICES}

January and February 1927

We love made a reduction of from 10 to $20 \%$ from our old tire price list for Jamuary and February. Note the Net prices as figured in this new price list. PRICES SUBJECT TO CHANGE WITHOUT NOTICE

These prices are not prepaid.

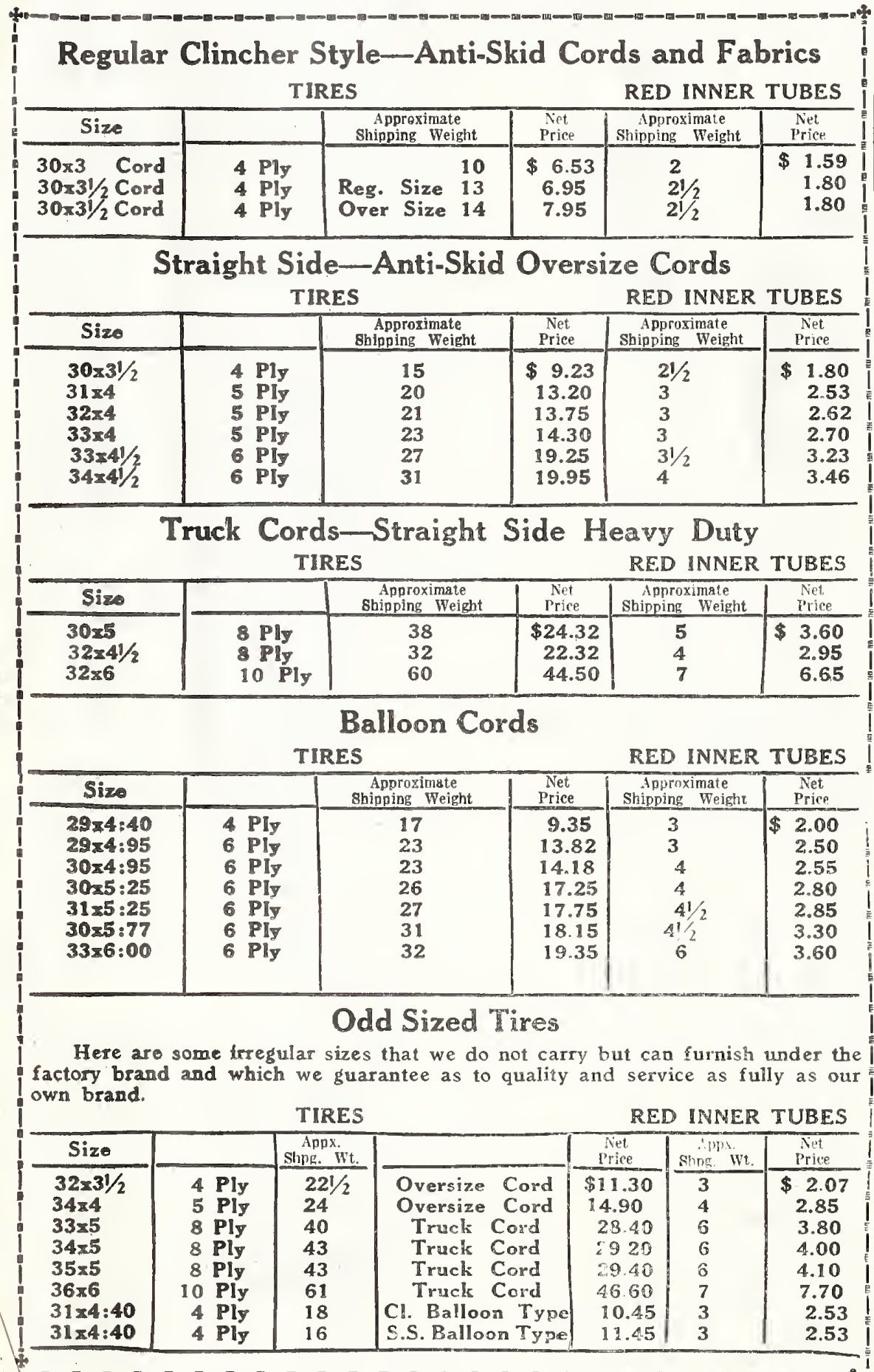

\section{T-Grip Tire Chains}

The Harder the Pull the

\section{Tighter the Grip}

Here is just the chain that will solve your troubles for a long time. They are all case hardened cross chains and the side chains are Heavy Premier Spring Steel with less joints to wear out than any other chain on the market.

These chains are highly endorsed by Mail Carrier's all over the country, and they sure give chains a good test.

Balloon Tire Sizes 3-0 Type

\begin{tabular}{|c|c|c|}
\hline Size & $\begin{array}{l}\text { Approximate } \\
\text { Shipping Wt. }\end{array}$ & Price \\
\hline $28 \times 4: 40$ & $141 / 2$ lbs. & $\$ 6.00$ \\
\hline $29 \times 4: 40$ & $141 / 2$ & 6.00 \\
\hline $31 \times 4: 40$ & $151 / 2$ & 6.50 \\
\hline $34 \times 4: 40$ & $171 / 2$ & 7.50 \\
\hline $29 \times 4: 95$ & 16 & 6.75 \\
\hline $30 \times 4: 95$ & $161 / 2$ & 7.00 \\
\hline $31 \times 4: 95$ & 17 & 7.50 \\
\hline $32 \times 4: 95$ & 18 & 7.50 \\
\hline $33 \times 4: 95$ & $181 / 2$ & 8.00 \\
\hline $34 \times 4: 951$ & $181 / 2$ & 8.00 \\
\hline $30 \times 5: 25$ & $161 / 2$ & 7.75 \\
\hline $31 \times 5: 25$ & 18 & 8.00 \\
\hline $32 \times 5: 25$ & $171 / 2$ & 8.50 \\
\hline $30 \times 5: 77$ & $161 / 2$ & 8.00 \\
\hline $31 \times 5: 77$ & 17 & 8.50 \\
\hline $32 \times 5: 77$ & 18 & 8.75 \\
\hline $33 k 5: 77$ & 28 & 9.50 \\
\hline $34 \times 5: 77$ & $181 / 2$ & 9.50 \\
\hline $35 \times 5: 77$ & 20 & 10.00 \\
\hline $32 \times 6: 00$ & 18 & 9.75 \\
\hline $33 \times 6: 00$ & $181 / 2$ & 10.25 \\
\hline $34 \times 6: 00$ & $181 / 2$ & 9.75 \\
\hline $32 \times 6: 20$ & 18 & 9.00 \\
\hline $33 \times 6: 20$ & $181 / 2$ & 9.75 \\
\hline $33 \times 6: 60$ & $181 / 2$ & 10.50 \\
\hline $34 \times 7: 30$ & 19 & 13.00 \\
\hline
\end{tabular}

Regular Tire Sizes 3-0 Type

\begin{tabular}{c|c|c}
\hline Size & $\begin{array}{c}\text { Approximate } \\
\text { Shipping Wt. }\end{array}$ & Price \\
\hline $30 \times 31 / 2$ & 14 Ihs. & $\$ 5.50$ \\
$32 \times 31 / 2$ & 15 & 6.00 \\
$30 \times 4$ & 15 & 6.00 \\
$31 \times 4$ & $151 / 2$ & 6.50 \\
$32 \times 4$ & 16 & 6.50 \\
$33 \times 4$ & $161 / 2$ & 7.00 \\
$34 \times 4$ & 17 & 7.50 \\
$35 \times 4$ & $171 / 2$ & 8.00 \\
$29 \times 41 / 2$ & $141 / 2$ & 6.75 \\
$32 \times 41 / 2$ & $177 / 2$ & 7.50 \\
$33 \times 41 / 2$ & $181 / 2$ & 8.00 \\
$34 \times 41 / 2$ & $181 / 2$ & 8.01 \\
$35 \times 41 / 2$ & 19 & 8.50 \\
$36 \times 41 / 2$ & 19 & 8.50 \\
$33 \times 5$ & 18 & 9.00 \\
$34 \times 5$ & 19 & 9,00 \\
$35 \times 5$ & $191 / 2$ & 9.50 \\
$36 \times 5$ & 20 & 9.50 \\
$37 \times 5$ & $21 ! / 2$ & 10.25 \\
$36 \times 6$ & 21 & 12.00
\end{tabular}

Extra Heavy Truck 5-0 Type

\begin{tabular}{c|c|c}
\hline Size & $\begin{array}{c}\text { Approximate } \\
\text { Shipping Wt. }\end{array}$ & Price \\
\cline { 1 - 3 } $32 \times 41 / 2$ & 22 Ibs. & $\$ 9.50$ \\
$34 \times 41 / 2$ & 24 & 10.00 \\
$30 \times 5$ & 22 & 9.50 \\
$33 \times 5$ & 25 & 10.50 \\
$34 \times 5$ & $251 / 2$ & 10.75 \\
$35 \times 5$ & 26 & 11.25 \\
$32 \times 6$ & 28 & 11.50 \\
$36 \times 6$ & 32 & 13.50 \\
$38 \times 6$ & 34 & 14.50
\end{tabular}




\section{GLASS CLOTH
Much Cheaper Than Glass and in Some
Ways Even Better Ways Even Better}

\section{A Perfect Substitute

\section{for Glass}

The new product, Glass Cloth, is in many ways superior to glass for hotbeds, cold frames, chicken houses, scratch sheds, for covering window openings and for making a screen porch into a sun parlor.

It is much cheaper than glass. Lighter to handle Does not break. Is almost as transparent as glass. Does not burn the plants in a hotbed and lets through more of the beneficial ultra-violet rays.

It's a good idea when putting glass cloth on frames doors, etc., to fasien it down with strips of wood such as are used to hold screen wire on doors. If you just tack it down, the glass cloth may tear away from the tacks; but the strips will hold it in good shape.

\section{Glass Cloth for Hotbeds}

The cloth is a medium weight whice muslin treated with a special preparation which makes it water-proof, translucent, weather-proof, and long lived. It comes in one width only, 36 inches or a trifle less, and in a standard size bolt of 15 yards. Can also be liad in 6-yard and 10-yard bolts. Try and order these regular sizes if possible.

Plants started in Glass Cloth hotbeds are hardier, srow faster and transplant better. The ultra-violet rays help the plants to grow. No spindly plants. Soft warm rays of the sun are thrown to all parts of the frame, leaving no dark corners as glass does. Uniform light produced by Glass Cloth gives the plants a smooth, even green color, stocky, hardy, vigorous growth, full of proper vitality to be set out in the open and produce a good crop.

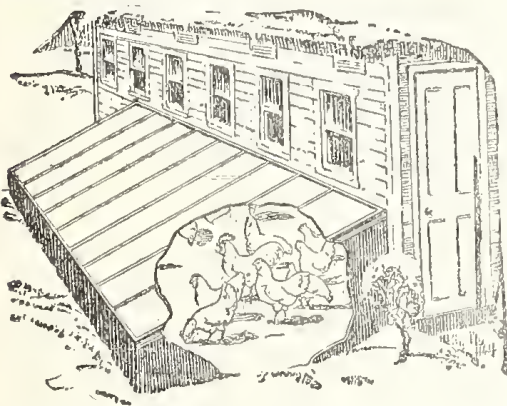

The glass hotbeds frames weigh over four times as much as ordinary frames covered with Glass Cloth. Why handle this weight every day when you can use Glass Cloâh, grow better plants and do it easier?

The frames can be made of light material which can be frequently picked up around the home or be bought at small cost, making the complete frames cost much less than regular glass siding.

While Glass Cloth will withstand hail about as well as zlass, if it should be ruined by hail as may possibly happen, it can be replaced for only a fraction of the price of glass.

Hotbeds Are Money Makers and Money Savers. Raise Your Own Plants and Sell to Your Neighbors

Glass Cloth is fully as efficient as glass in stopping cold, water and wind, at the same time is transparent and admits the light and warmth of the sun as readily as glass. In fact, whereas glass is a conductor of cold, Glass Cloth is not. While Glass Cloth is thinner than glass, it does not conduct cold and thcrefore its resistance to cold is greater.

\section{SPECIAL PRICES-GLASS CLOTH}

15-yard bolt (1.35 sq. fect) postpaid _.... \$5.00

10-yard bolt (90 sq. feet,) postpaid _.... 3.50

6-yard bolt (64 sq. feet) all postpaid _... 2.25

This figures out less than $4 \mathrm{c}$ per square foot in full bolts, or one-fourth to one-eighth the cost of glass.
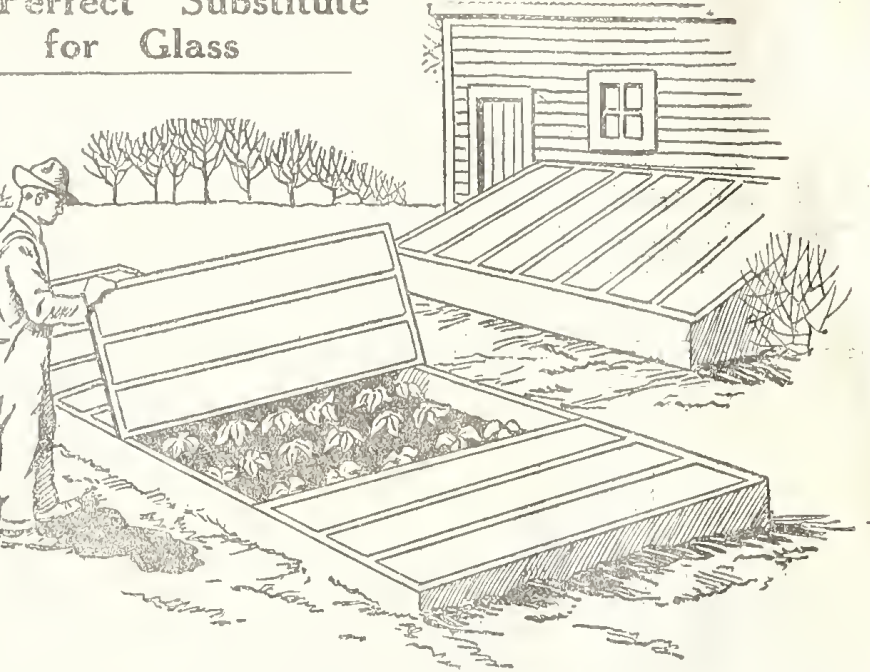

CHICKS THRIVE IN VROLET RAYS

Never put baby chicks behind glass. It stops the sun's violet rays and causes many weaknesses and diseases of chicks. Use Glass Cloth only. In a test at Ames College 25 percent of the chicks under plain glass died, while all under Glass Cloth lived and grew thriftily.

GLASS CLOTH FOR CHICKEN HOUSES

This Glass Cloth is just the thing for covering scratch pens, brooder house, brooder pens, fronts for hen houses.

GLASS CLOTH SCRATCH SHED BRINGS EGGS ALL WINTER

It is easy to get lots of eggs all Winter by just. building a Glass Cloth scratch shed on to your hen house: cheap and easy to build. Glass Cloth admits the sun's ultra-violet rays, which would be stopped with the gläss. "This' ultra-violet cnergy has an amazing effect on the vigor. and egg yield of hens. In zero weather they lay like it was spring. Give them straw to scratch in. The exercise feeds their circulation, makes the body heat, increases vitality; aids digestion. High priced Winter eggs will pay for this scratch pen many times over each season. Try it. It is a real Winter money maker for you.

Glass Cloth is ideal for scratch sheds, poultry and brooder house windows and all such uses around a poultry ranch.

PRICES ON GLASS CLOTH INCLUDE POSTAGE

The prices quoted on Glass Cloth include postage, prepaid. All express charges or freight charges to add.

If you need large quantities to come by freight or express, say quantiies of 50 yards or over, write for special prices.

MARE A SUN PARLOR OF YOUR SCREEN PORCH

That screen porch of yours can easily be turned into a comfortable and practical sun parlor, by enclosing your porch for the Winter months with Glass Cloth over the screen wire

This will improve the comfort and size of your entire house by the protection from the weather which an enclosed porcl gives and the extra room which the porch provides.

The Glass Cloth will let the light through practically as freely as glass, but will stop the wind, cold and snow an make a comfortable room instead of a snow trap out of your screen porch.

Except in the very coldest Winter weather, your screen porch cau be made perfectly comfortable for every-day use and it makes a wonderful play room for the children. Violet rays coming through the Glass Cloth make it an ideal place for chilidren.

\section{GENUINE GLASS CLOTH IS PATENTED}

Genuine durable Glass Cloth is made by Turner Brothers under exclusive patent and is their product we sell.. No other concerns can copy their patent. No other has the same weathex resistant formula. Real Glass Cloth is a strong fabric, specially treated to make it transparent, water-proof and weather-proof. 


\section{Ladies' Arch Health

\section{COMFORT and HEALTH combined with STYLE and SERVICE}

Thousands of orders from all parts of the country as well | tion lasts, insuring comfort for the ball of the foot with close as literally hundreds of unsolicited testimonials, proves that fitting ankle heel and instep. Built in arch support of guaranour Radio Arch Health Shoes are Proving Satisfactory and teed unbreakable chilled steel, long counters that prevent run that they are filling in wonderful shape the popular demand over heels, Spring-step Rubber Heels. Every Radio Arch for a good looking servicable guaranteed Arch Support Shoe, Model Described Below are made according to these speciat a reasonable price. Factory specifications include combina- fications.

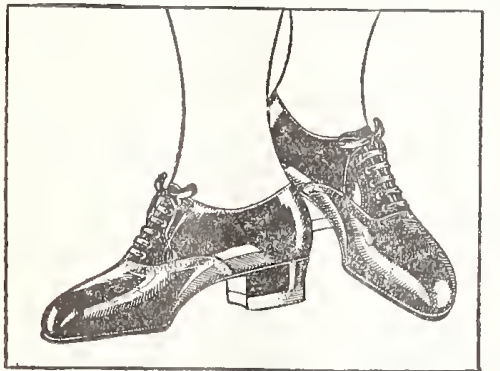

\section{Order By Stock Numbers-Be sure to State Your Size and Width}

\section{No. 3 Women's Work Shoe}

This model is made of extra heavy black glazed kid, imitation tip, stitched across but no tip, overweight Goodyear welt sole, a wonderful service shoe for farm wear, and dressy enough for anytime. Has a round toe which is good and roomy. The heel is a little over an inch high and is rubber tipped. Also has the built in arch support which is a great relief for tired, sensitive feet. This model comes in sizes and half sizes $31 / 2$ to 9 . Two widths, Medium and wide. Price $\$ 4.50$ Plus Postage for 2 pounds.

\section{No. 4 Radio Arch Fancy Cut Out Tie}

A dressy tie with all the practical qualities of the oxford. This model is made of fine high grade Black glazed kid. Plain toe (no tip). A newly designed cut out pattern adds much to the attractiveness of this model and the heel is military in design 1 5-8 inches high, rubber capped. The design makes this model very effective with colored hosiery. Just the same as the other Arch Health shoes it is leather lined throughout, which protects the hosiery and adds to the life of the shoe. Sizes and half sizes $31 / 2$ to 9. Two widths, Medium and Wide. Price $\$ 4.50$ Plus Postage for 2 pounds.

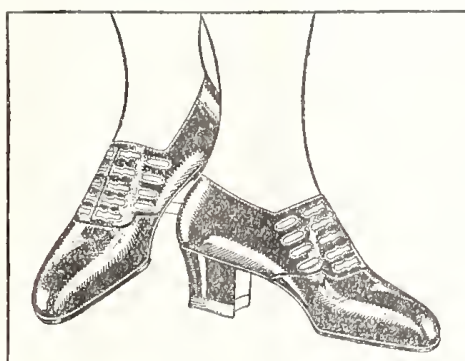

\section{No. 6 Radio Arch 3 Button Closed Front}

This model is the season's favorite and a most practical and dressy model for matron or maid. Newly designed cut out pattern on front and sides. Plain toe (no tip). 1.5-8 inch rubber heel. No. 6 model is a lustrous black patent leather. Sizes and half sizes $3 \% / 2$ to 9 . Two widths, medium narrow and medium wide. Price $\$ 4.50$ Plus postage for 2 pounds.

\section{No. 7 Model-Our Favorite}

No. 7 model is exactly like No. 6 in every detail except it is made of fine high grade black kid leather and comes in sizes and half sizes $31 / 2$ to 9 . Three widths, Narrow, Medium and Wide. Price $\$ 4.50$ Plus Postage for 2 pounds.

\section{Shoes and Comfort}

striction used in the making of all our Comfort Shoes is the Our Comfort Shoes are carefully selected styles from one of extremely flexible hand turned sole process. The uppers are the most famous factories in the country specializing on of high grade Genuine South American Kid, because it is soft, Comfort Shoes. Comfort Shoes are in universal demand by comfortable and conforms quickly to the foot. Soles are of women who have tender sensitive feet, who can endure nothing soft flexible oak-tanned leather of good thickness and quality.

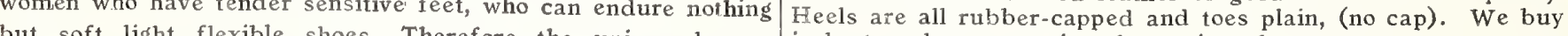
but soft light flexible shoes. Therefore the universal con-lin large volume-passing the saving along to you.

NO. 10 REAL COMFORT HIGH SHOE NO. 2 MILITARY HEEL TOW STRAP $3 \frac{1 / 2}{20} 9$. Two widths, Medium and Wide.

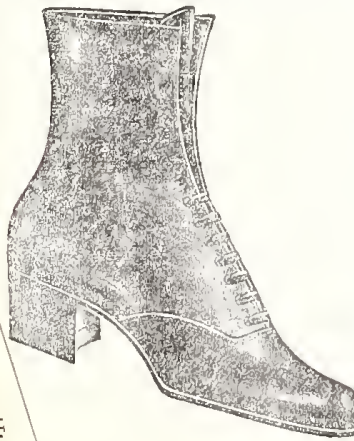

Soft Kid leấher, flexible hand turned sole, plain toe, low 1.1.8 inch rubber capped heel. Sizes and half sizes, $31 / 2$ to 9 . Two widths, Medium and $\$ 3.35$ ristage for 2 sure to wear well. A shoe you'li just Wide. Price $\$ 3.20$ plus postage for 2 pounds.

Price $\$ 3.30$ plus postage for 2 pounds.

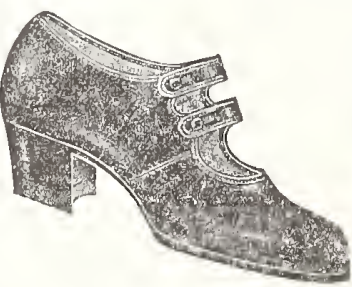

This model is about the same as No. 1 except that it is two strap instead of lace and has $\mathrm{s} \circ \mathrm{mewhat}$ higher military rubber capped

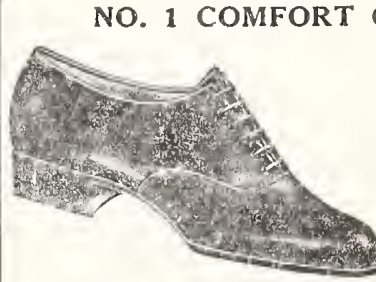

Black Kid, plain toe, hand turned sole, low 11-8 inch rubber capped heel. Perfect comfort for street or home. We guarantee rice heel. Soft Kid leather, flexible hand satisfaction in every pair. Sizes and half
plus turned sole. An all purpose shoe that is sizes $31 / 2$ to 9 . Two widths, Medium and 


\section{GENUINE HORSE HDDE, ${ }^{\top}{ }_{\mathrm{E}}$ FARMER'S FRIEND}

No. 1. Genuine Horse-Hide

Leather

Genuine Horse Hide Leather

Flexible Horse Hide Soles.

U. S. Rubber Heel.

Sewed with Pure Silk and Linen Threads.

Sizes 6 to 12 Price, $\$ 4.00$ Postage 4 lbs.

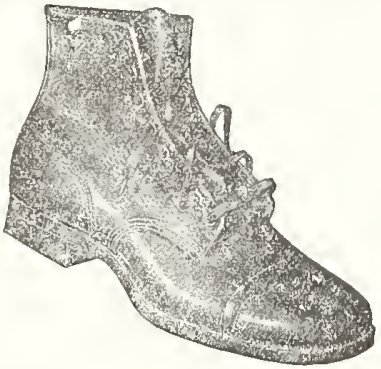

No. 2. Genuine Horse-Hide

Leather

Nailed and Sewed Grease Filled Soles

U. S. Rubber Heel.

Heavier Weight Shoe.

Sizes 6 to 12. Price $\$ 3.50$ Postage 4 lbs.
Spring time is just around the corner and it's time for the Farmer to begin to think about his Shoes. The Horse-Hide Shoe is the Ideal Farmer Shoe because of the fact that it does not get hard, the damp days of spring do not affect the HorseHide Leather, it always stays soft, water will not make it hard, therefore you do not have that uncomfortable feeling of stiff, hard shoes to do your work in. You really smile when you get up in the morning and find those shoes that were soalking wet the night before as soft and pliable as a glove. Of course î́'s better not to get them wet too much as it does hurry along the life of the shoe unless you keep them well oiled, but no matter how careful you are, they are likely to' get wet, and then is when you appreciate Horse-Hide Shoes. These shoes are as comfortable as a moccassin, bend with every step of the foot, unusual for a work shoe that will give such long wear.

\section{Calf Skin Oxford for $\$ 5.00$}

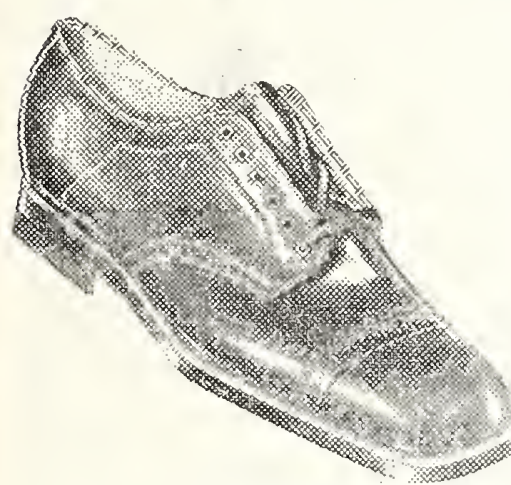

Cenuine Calf-Skin from Top to Bottom.

Goodyear Welt Sewed Soles.

Latest Cut On Market. Taio Soles if Preferred. U. S. Rubber Heels.

This is where we shine with the Young Fellow who does not care to pay such high prices for shoes, a Genuine Calf-Skin Oxford, made up in the very last word in style, either $T$ an or Black. Just because we have a good reputation for shoes that wear is no resaon why we can't give you the style you want. Every Three Months we change the style of these Oxfords so our Young Men customers can wear just as late models as can be had. Our specialty is st; le with these Oxfords and yet the same care is taken to put quality in the Oxfords that we do in all the rest of our Footwear. Sizes 6 to 12, medium and wide. The price is only $\$ 5.00$. Postage 4 pounds.

\section{Horse-Hide Shoes for Roys}

Genuine Horse-Hide Leather Nailed and Sewed Soles.

Leather Heel.

Double Cap Toe.

Here we go, a boys shoe that will wear till the boy outgrows them, he might wear the sole out, but you can resole them and they will give wonderful wear. The leather is Horse-Hide and that means wear and stay Soft. Solve the Everyday

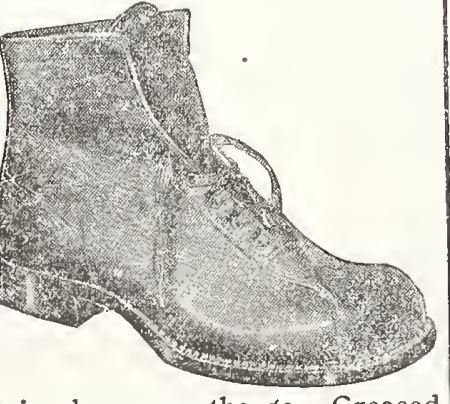
Shoe Problem for the boy that is always on the go. Greased Filled Soles, outing style. All sizes from $11 \frac{1}{2}$ to $5 \frac{1}{2}$. Priced at $\$ 3.00$. Postage 3 pounds.

\section{Real Kangaroo Shoes for $\$ 5.00$}

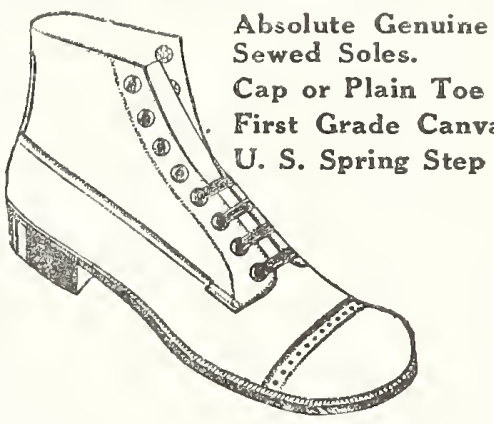

Leather for Fields Dress Up
Kangaroo Leather.

sining.

We had the world beat on Kangaroo in 1926 but you send in your order now for the 1927 Kangaro'o and you will quickly see that we have been on the job getting the best ever Kangaroo Shoes. Genuine Kangaroo Leather, imported from Australia. Shines almost like Patent Leather, and wears better than most any other fine grade of shoes, does not scuff or peal. These shoes are made over the Broad Toe Lasts and fit easy to the feet. Rubber heels and Blacher Style. One thing that makes the Filled Kangaroo so popular is the grade of shoe we have and the very low price, 6 to 12 , Medium and wide. Postage 4 pounds. Price $\$ 5.00$.

\section{WHY PAY BIG PRICES FOR YOUR}

\section{CHILD'S SHOES}

$81 / 2$ to 11 _. $\$ 2.45$

$111 / 2$ to 2 . 2.75

Postage for 2 pounds

This model is made of Elk tanned leather over a good Nature Form Last which insures proper growth for your child's foot. Sewed soles with low rubber heels. Can be had in an oxford or shoe.

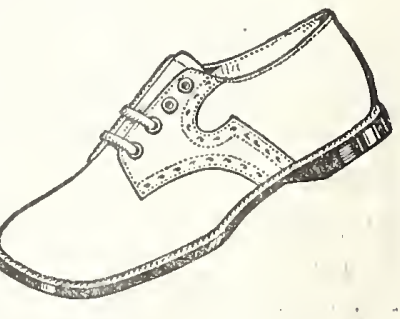

\section{Important}

If you don't know your size send along an outline drawing of your foot, also the lining number in your shoe. Our shoes are sold the same as our other merchandise-"Satisfaction or your money back." 


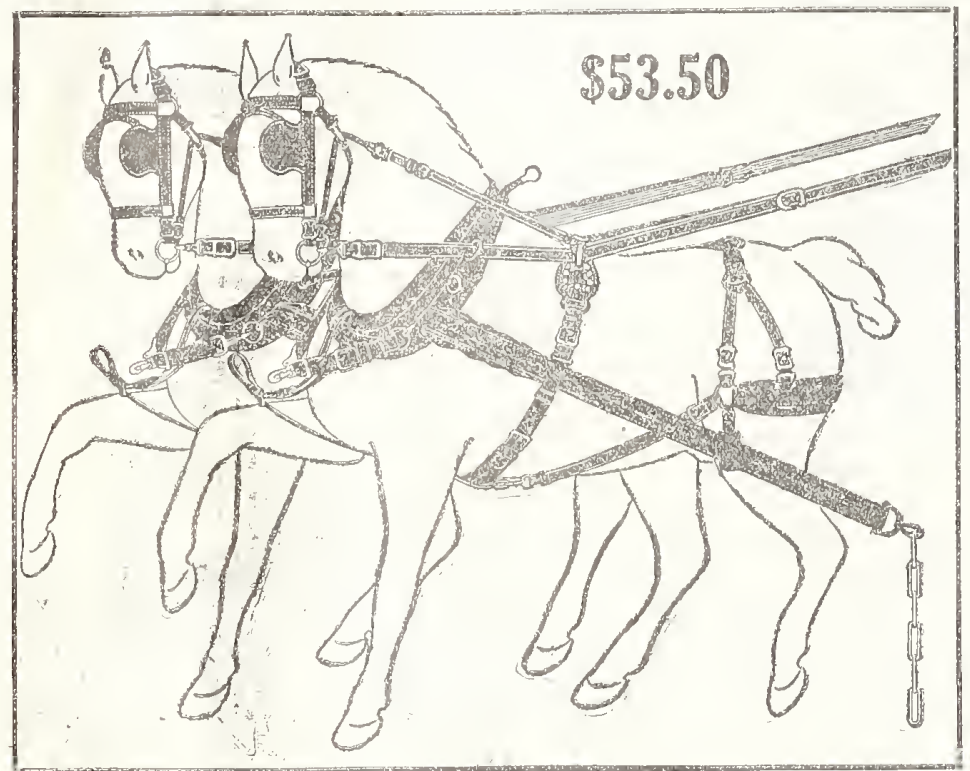

\section{FIELD'S BETTER GRADE HARNESS}

Now folks, if you want cheap harness, we can furnish you cheap harness at $\$ 37.50$, complete with breeching. But we would rather not sell it to you because we know that you would be better satisfied wth the better harness which we sell. All of the harness listed in the harness catalog is the very best quality and workmanship that you can get any place and we are selling it at real money-saving prices.

This is a new harness that we have added to our line this season. It is made with a hook and terret pad so that you can rein your horses up to the back pad. The lines run through the terret rings on the back pad and this model liarness does away with the straps that run through to the hames. We have had many requests for a hook and terret harness and so have made this set up particularly for the people who like this style of harness. Send for Special Harness Catalog.

\section{Specifications}

BRIDLES-1 $1 / 4$ inch ring crown, combination front and winker / from ring on back to hook on back pad.

braces, heavy 1 inch cheeks.

LINES-11:8 inch by $20 \mathrm{ft}$. long, 1880 buckles and snaps.

TRACES-Heavy: three ply, 6 link swivel heel chains. 11/2, inch belly band billets.

BACK PADS- $51 / 2$ inches wide, doubled and stitched making

\begin{tabular}{l|l} 
a solid leather pad. \\
BACK, STRAPS-1 1.8 inch wide, adjustable strap running
\end{tabular}

BREECHING-21/2 inch single strap with $1 \frac{1}{2}$ inch layer sewed around breeching. $1 \frac{1}{2}$ inch reverse hip straps. $11 / 4$ inch reverse belly straps.

POLE AND BREAST STRAPS- $1 \frac{1}{2}$ inches wide combination snap and slide.

BELLY BANDS-11/2 inch solid leather with $1 \frac{1}{2}$ inch belly No. 602 Price per set without collars, $1 / 2$ inch traces

No. 603 Price per set, without collars, $13 / 4$ inch traces and $13 / 4$ breast and pole straps

With regular Concord style back pad,

No. 802 Price per set, without collars, $11 / 2$ inch traces

No. 803 Price per set, without collars, $13 / 4$ inch traces

$\$ 56.50$

Same harness as Nos. 602 and 603 , nnly without back pads, trib straps running to belly band billets, and to ring in hames.

No. 1702 Price per set, $11 / 2$ inch traces

No. 1703 Pricé per set, $13 / 4$ inch traces

\section{Field's Favorite Collar}

Here is a real honest-to-goodness collar for the money. It is made from grained leather, and is an all russet horse or mule collar. Remember, if not satisfied with any of your orders in horse or mule collars from us, all you have to do is send them back

\section{DESCRIPTION}

About 18-inch draft, $1 / 2$-inch hand thong inner and outer seams, 11/4-inch laced-on billet and buckle. Large Curtis sole leather pad, extra large hame rim. Full grained leather back all in one piece. Extra reinforcèd throat. Best 8 oz. Oak-tanned collar leather.

ALC SIZES up to and including 22

inch -

No. S05. Hulf sweeney, for thick-necked horses - - _.

No F04. Straight or full face for mules or thin-recked horses _._._._....... \$4.45

Sirte. 23-inch in either style _._.... 4.95

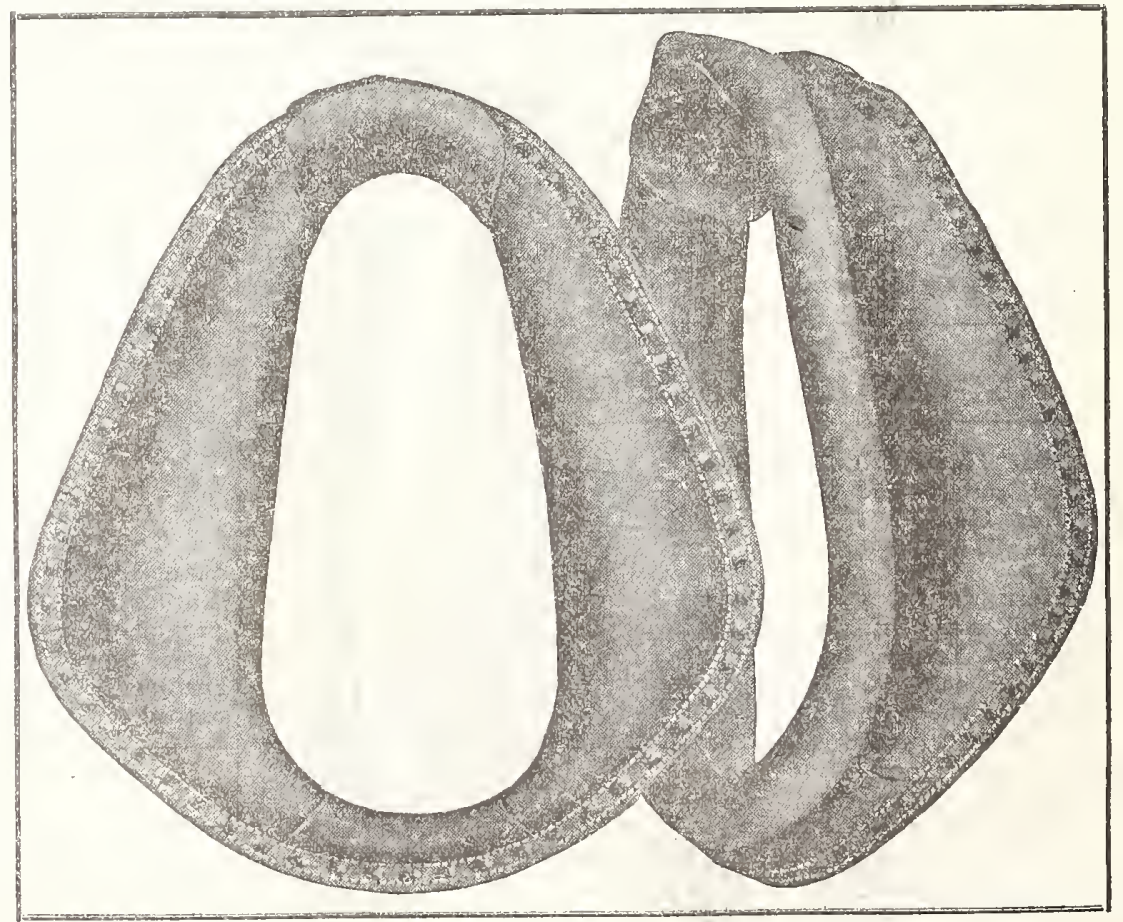




\section{Field's Metal Re-enforced Harness}

We believe we have the best metal to metal harness in America at any price. Metal to metal construction means just what it says: Metal touches metal wherever there is seasaw or friction. At these points no leather is asked to do the work without protection by the tough, long wearing metal. This is no new or radical idea in harness construction and the wonder is that this style of construction was not used long before. Metal is always placed at the ends of traces.

If metal is placed there, why should it not be placed other places on the harness. No matter how good the leather, it is sure to wear first where there is friction with metal. Parts which are not required to stand this wear easily outlast straps where this friction and sea-sawing takes place. It is plain that friction cannot be stopped in any harness, but metal to metal construction reduces damage from friction to a minimum.

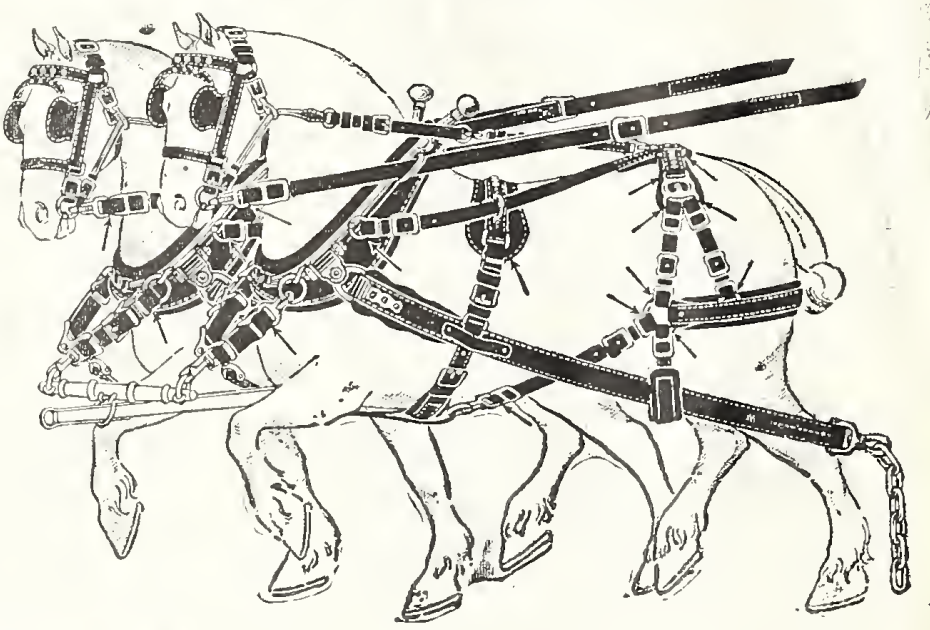

\section{Specifications}

BRIDLES-Ring crown style 7.8 inch cheeks, 1 1.4 adjustable the wear comes with metal.

crown, doubled and stitched, combination front and winker TRACES-Heavy 3 ply, $6 \mathrm{ft}$. leather, 11/2 inch; 6 link heel braces, logn round rein extending to pad, brass spotted fronts. chains and swivel clevis; wide scalloped safe at front, atLINES-1 1.8 inch, 20 feet long, with 1880 buckle snap in- tached to bolt hames with metal attachments.

cluded. Metal reinforced.

BACK AND HIP STRAPS-1 1.8 inch of good solid stock. HAMES-All steel, black with $13 / 4$ inch solid brass balls, fit Brass spotted drops on hip straps. Metal reinforced.

18 to 24 inch collars; spread straps $3 / 4$ inch, 11 inches long BREECHING-21/4 inch single ply breeching with $1 \frac{1}{4}$ layer with rings.

BACK PADS- $43 / 4$ inches wide; two thicknesses of leather possible to wear on leather.

doubled and stitched, $1 \frac{1}{2}$ inch layer sewed on pad, brass POLE AND BREAST STRAPS-11/2 inch good heavy stock, spotted. Japanned bridges.

and combination snap and slide attachment. $7 / 8 \times 7 \mathrm{ft}$. hitch reins. MARKET STRAPS $-1 \frac{1}{2}$ inch double, and reinforced where This harness is made plain with no creasing.

No. 702 - Price per set, without collars, $11 / 2$ inch traces

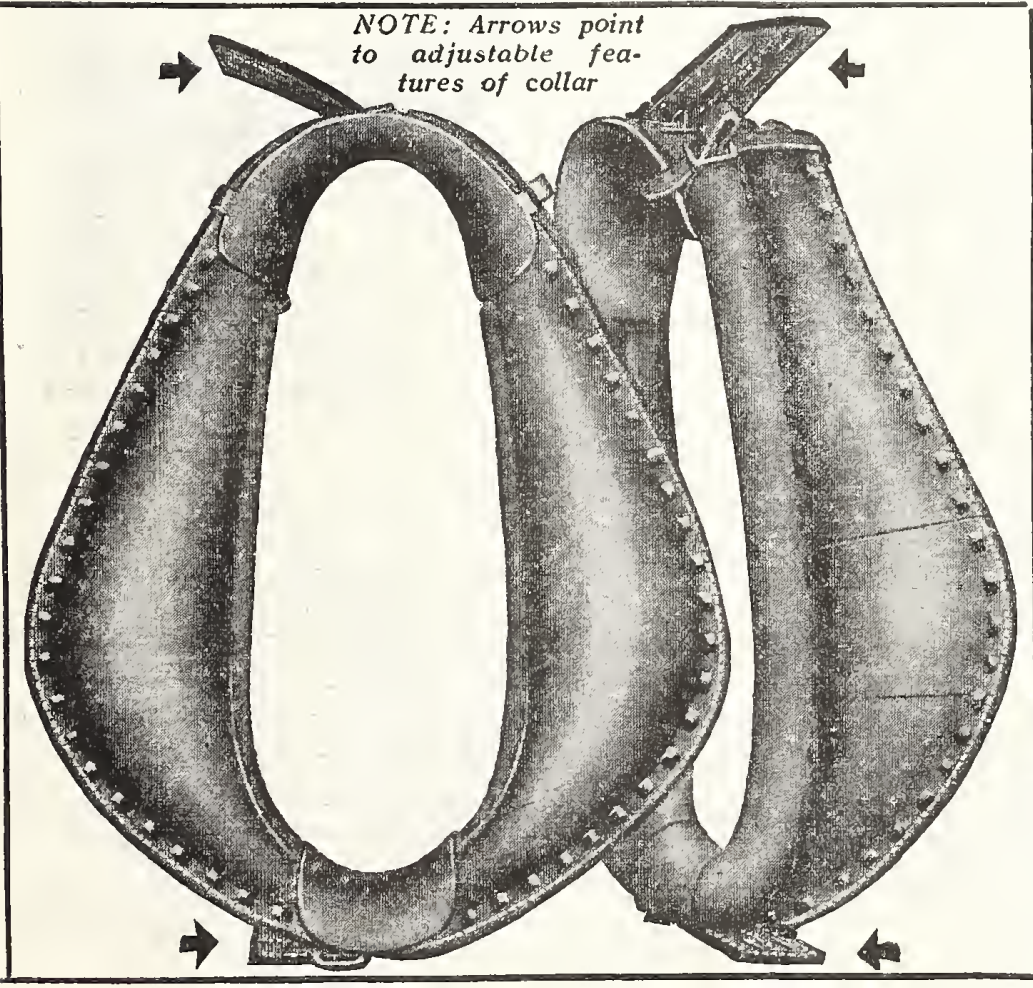

\section{Field's Perfect Fit Collar}

We have long felt the need of an adjustable collar that really adjusts. One that would meet the changing conditions of the work horse frotn early spring to mid-summer. As the horse hardens to heavy spring work, its neck and shoulders shrink at all points, but to meet this change, the so-called adjustable collars only take up in length.

We believe we have the answer to these needs in the Perfect Fit Collar. It has perfect adjustment at the top and bottom, absolutely insuring a "Perfect Fit" all the time and at all points.

The Perfect Fit Collar is made of the best all Russet collar leather. Wide outer seam and thong inner seam, stuffed with clean rye straw and hair-faced. Heavy hame rim, has a large sole leather pad 10 inches long at the top with straps and buckles, perfectly smooth for the neck. This bottom construction makes it exceptionally strong, so that it will not break or give away as many collars.

This collar can be adjusted for length and width. No. 101 - Price each, any size, top and

bottom adjustment, full face $\$ 6.75$

No. C100-Price each, any size, top and

bottom adjustment, half sweeney.

NOTE: Be sure and state size and style wanted. 


\section{IRUD'S IOWA PAINTS}

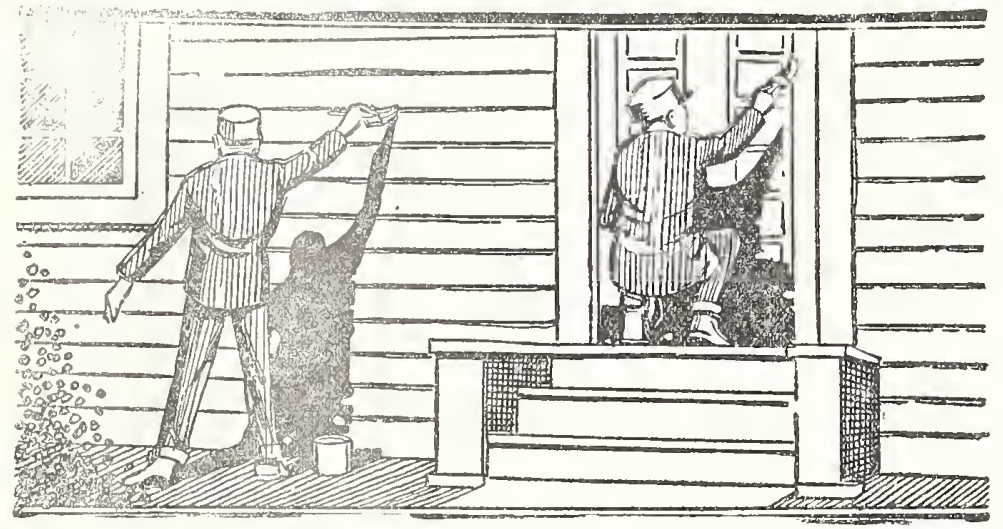

I am a great believer in the use of paint. It helps the looks of a place immensely Makes it look like a home. Looks like somebody lived there and $w$ as proud of it. If you want to sell your place, paint will add ten per cent to the sale value and at a very slight cost. Paint saves you money in the long run, by protecting and preserving the wood. You all know this. The only trouble is that it has been too higll. At least it looked that way. From $\$ 3.25$ to $\$ 4.00$ for a reasonably good paint always looked like too much money to me. You probably felt the same about it.

I have been figuring for a long time with one of the largest paint factories in the country, real paint men, who knew I had to have an honest-to-goodness paint for a fair price, if I had any at all. After we traded ideas, they gave me a real low figure mostly because they knew I would sell quite a lot of it. That's usually what decides a price-how much you can sell of a thing. My prices are naturally lower than most dealers can make, even though he sells an inferior grade of paint.

Anyway, I will sell you a ligh grade, guaranteed paint at the prices below. It is made to stand the hard conditions of Iowa, Nebraska, Kansas and Missouri weather. It will look well and last well. Carries our name and 0 . $\mathbf{K}$, and is made by a factory that knows paint from A. to $Z$.

If you appreciate this kind of a deal, get busy and send us your order. Across the page is how to measure your house for paint and a suggestion about the barn. All the paint you order has got to suit you or you can have your money back.

\section{As Others See Us}

We are liable to get so used to seeing our own house without painting that we really don't know how badly the place needs fussing up. It would be expected if it cost a fortune to paint up. But it doesn't, and with the paint prices here there is no excuse any more.

Just imagine what you can do to beautify the house with a few cans of paint. Its worth the price in the pride you will feel.

Sit down and figure out how little it will cost to put a new suit on your house and barn. I'll make a guess that if you do that you'll do more. Your order will be handled promptly; of course the paint is guaranteed.

Don't stop when you have the house in bright, tip-top shape. Barns and other buildings have got the same weather to stand and deserve the same care and attention. Give the whole place a clean face for everyone to see. You can paint the house, barn, other buildings and even the fence for what it used to cost to do up the house. All our paints will return their cost many times over in saving expensive repair bills that come from putting of painting year after year. The attractiveness of your place counts too.

In 5-gallon cans (shipping weight 70 lbs.) $\$ 2.40$ per gal. In 1 -gallon cans (shipping weight 17 lbs.) 2.50 per gal. In $1 / 2$-gallon cans (shipping weight $9 \mathrm{lbs}$.) 2.60 per gal.

Shipped promptly, direct from factory near here. Freight is not prepaid

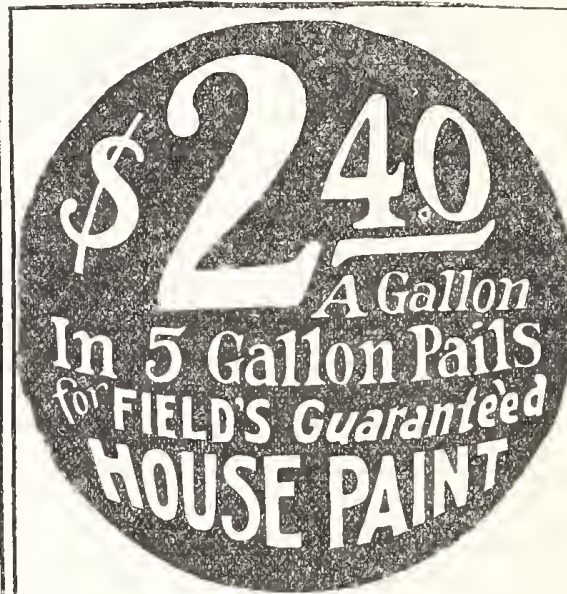

We have these shades and colors in house paint, both gloss finish and flat tone for inside walls.

Inside White

Outside White

Ivory

Euff

Cream

Leather

Chocolate

\begin{tabular}{|l} 
Cherry Red \\
Slate \\
Pure Gray \\
Sky Blue \\
Lt. Green \\
Moss Gree
\end{tabular}

Also floor paint in Grey, Tan and Brown.

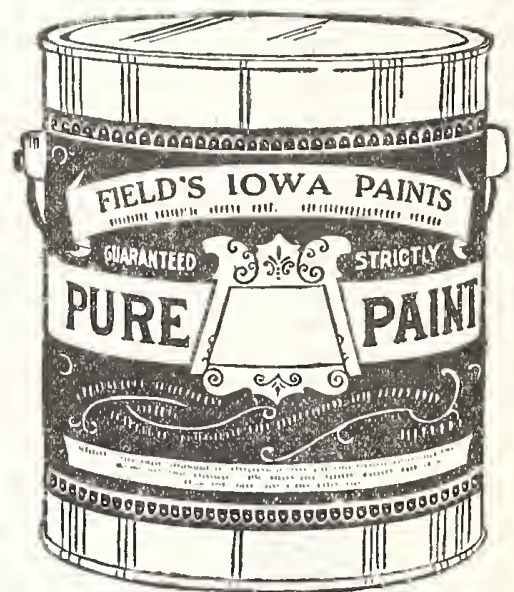

CRYSTAL FLOOR VARNISH AND VARNISH STAINS

Gallon $\$ 2.80$

Half Gallon 1.60

Quart

\section{OUTSIDE SPAR VARNISH}

Gallon $\$ 3.50$

Half Gallon _......... 1.90

Prices f. o. b. factory. Shipping weight about 12 lbs. to the gallon.

Wear and tear goes on inside the house on floors, wood-|floors, walls and furniture, and gives a beautiful, elastic and work and furniture; so frequent and timely applications of durable surface. Our Outside Spar Varnish is adapted to varnish is not only good business judgment in preserving all outside uses where there is weather exposure. values but also pays us big dividends in the added pride and satisfaction we have daily in our homes.

Our superior Crystal Floor Varnish is good alike for and at the same price as Crystal Floor Varnish. 


\section{FIELD'S BARN PAINT}

Our barn paints are manufactured by the same company that makes the house paints. Same high grade quality materials and the same satisfaction guaranteed. And, now with these prices as low as they are, I guess you will either have to paint the barn or at least say that price isn't the reason any more. We have the two most common and popular shades for barns: Bright Red and Slate Gray.

BARN PAINTING. If your barn has a higin saile, allow paint for this space. Multiply width of barn by the height of the $\mathrm{fa}^{\prime}$ le $a \mathrm{~b}^{\mathrm{m}} \mathrm{e}$ the corner posts. Divide the number of square feet by the covering canacit", and this gives you paint for gables. About one gallon of trimming to ten gallnns of bad

Bright Red in 5-gallon cans (shipping weight $70 \mathrm{lb} \cdot$ ) Per Gal. Bright Red in 1 -gallon cans (shipping weight $17 \mathrm{lb}$ ) $\$ 1.35$ Slate Gray in 5-gallon cans (shipping weight 70 lbs.) 1.40 Slate Gray in 1 -gallon cans (shipping weight 17 lbs.) Freight is not prepaid. Shipped promptly, direct from factory near here.

\section{How to Measure Your Buildings for Painting}

Measure length width and height. Add together the total length in feet of the two sides and two ends of the building. Multiply this by the height of the building at the eaves with 2 feet added for cornice. This gives square feet of surface to be painted.

Thus: Your building measures 26 feet wide, 33 feet long and 22 feet high, you would figure it:

Front
One side
Rear -
Other Side
$\quad$ Total
Multiply this by height, plus 2 feet for cornice
$\quad$ Total

\section{Field's Stock Dip}

We are having manufactured for us pure, coal tar, creosote stock dip of the regular type which is used for horses, cattle, hogs, sheep, goats, poultry or other similar disinfecting purposes.

It is extra good quality and the usual kind that is used is diluted with from 60 to 75 parts of water, preferably soft water.

Here are the prices f. o. b. Shenandoah, you pay the express:

1-gallon can $\$ 1.10$ per gallon

2-gallon can

3-gallon can

5-gallon can

10-gallon can

30-gallon drum

50-gallon drum

These prices include containers free without extra charge.

\section{SEND ORDERS TO US}

Send your orders direct to us, Henry Field Seed Company, Shenandoah, Iowa, and we will make shipment promptly by either freight or express.

Or, if you prefer, you can call at the seed house for it for we have it in stock here at the seed house.

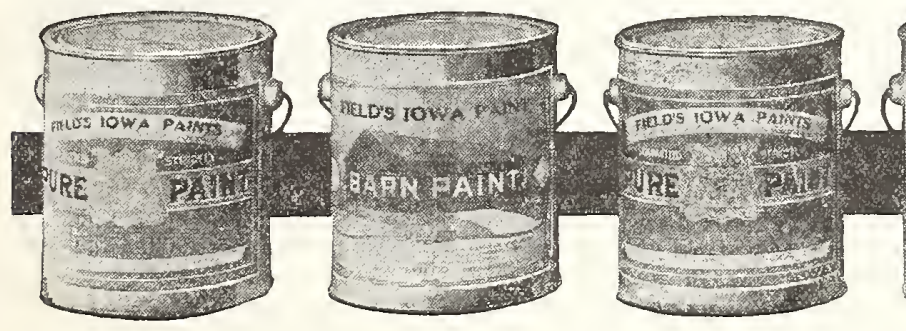

1.10 per gallon 1.10 per gallon 1.00 per gallon .95 per gallon .90 per gallon .90 per gallon

on

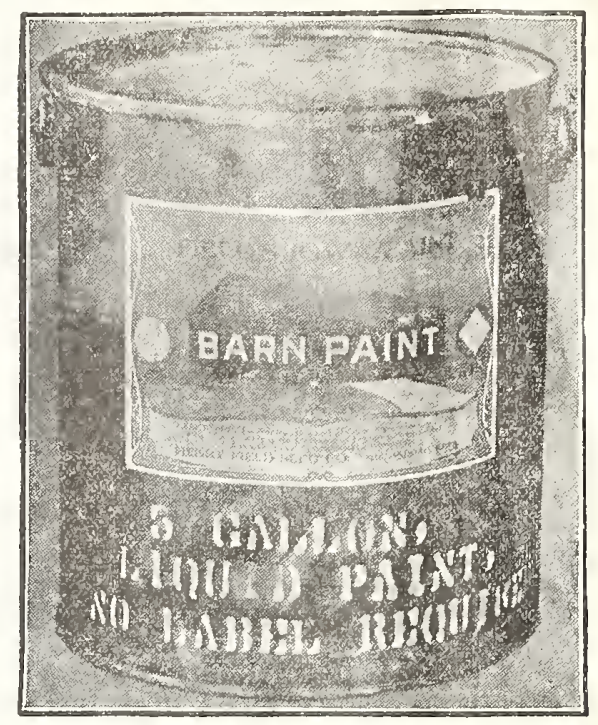

OUR GUARANTEE

We absolutely guarantee our dip to give satisfaction. If it does not after a fair trial, return it to us and we will either replace the goods or return your money.

\section{REMEMBER THIS}

The square feet of covering capacity of any paint depends upon the surface over which it is applied. A badly weathered surface will require twice as much paint as a surface in good condition.

There are 231 cubic inches in every full gallon of paint, regardless of the brand. Do not be deceived by claims for the spreading of paints, for common sense will tell you that the larger the surface to a gallon of paint, the thinner the film will be.

THE COVERING CAPACITY OF PAINT

No. 1-For poor surfaces where no paint has been applied for 12 to 18 years, and the wood is bare and porous. For three coats divide the number of square feet by 100 .

No. 2-For fair surfaces where paint film is thin and chalking. For two coats divide the number of square feet by 180 ; for three coats divide by 125 .

No. 3-For new wood three coats are necessary. Divide the number of square feet by 165 .

No. 4-For good surfaces, two coats, divide the number of square feet by 250. For one coat divide by 500 .

About 1 gallon trimming to 5 gallons of body. 


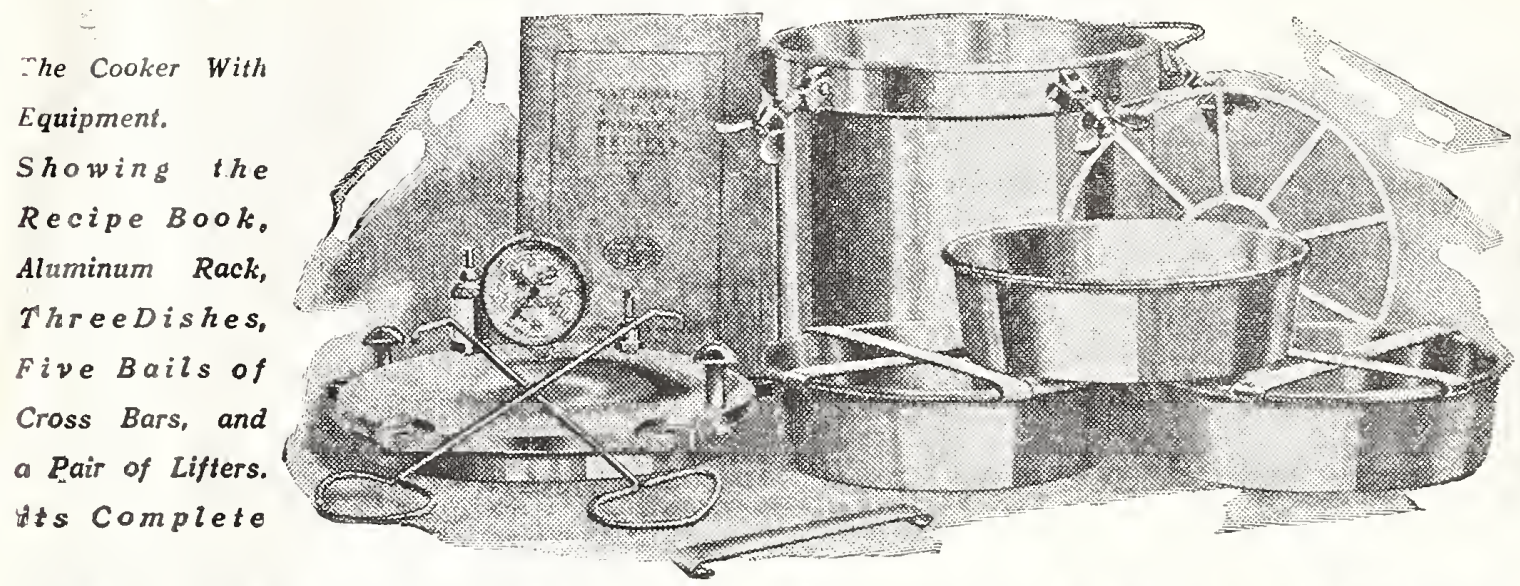

Our Guarantee

-he Cooker With

quipment.

Showing the

Recipe Book.

five $B$ ails of

Cross Bars, and

a Pair of Lifters.

tos complete

\section{"NATIONAL" PRESSURE COOKERS}

I consider the National Pressure Cookers and Canners the greatest modern advance in cookery. and I think that every housewife should have one, so I have put the price down where you can buy one. They are absolutely safe and "fool-proof", economical, and practical. They are guaranteed both by us and by the factory.

Ask your county agent, your home extension agent, or any hoine economics teacher about Pressure Cookers in general, and the National in particular. The National is made of cast aluminum.

When properly cared for National Cookers may be used three times each day, and will last a lifetime.

\section{Dimensions and Capacities of Cookers}

Liquid Capacity, Quarts _-_._-_._-_._- 12

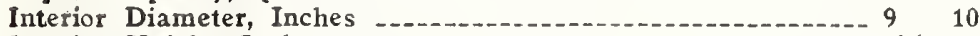

Interior Height, Inches _................ $81 / 4 \quad 9$

Net Weight, Lbs, ................. 12

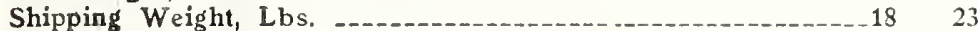

Will Hold-Pint Jars _.............. 5

Will Hold-Quart Jars .............................................. 3

Will Hold-2-Quart Jars _.............. 0

Will Hold-No. 1 Cans $(1 / 2$ pt.)

Will Hold-No. 2 Cans ( $\mathrm{Pt}$.) _......... 6

Will Hold-No. 3 Cans (Qt.)

10-quart cooker is for a family of four persons.

12-quart cooker is for a family of seven persons.

18-quart cooker is for a family of ten persons.

25-quart cooker is for boarding houses, etc.

\section{Save Time and Money}

The National cooks thoroughly, quickly and without waste. It preserves all the flavor and goodness of the food. Three separate dishes may be cooked at the same time without blending flavors.

old hens and roosters, if cooked 40 minutes in a National Cooker will be as tender and nutritious as spring chicken \begin{tabular}{ll|l}
18 & 25 & which costs very much more. Similar sav- \\
$111 / 2$ & $121 / 2$ & ings can be made with cuts of beef, mut-
\end{tabular}

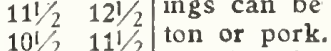

Judge from your own experience and I am sure you housewives will have to admit that the National will save you many a long hot hour in front of the stove. Just compare National time with open viessel time. The National will cook pot roast or ham in 50 minutes, pork and beans in 40 ininutes, chicken in 30 minutes, string beans in 15 minutes, potatoes or cabbage or steamed puddings in 10 minutes. Call you come anywhere near that? And it don't need to be watched every second, either. Every home in the United States needs National Pressure Cooker. It isn't an expense-it is an investment which will commence to pay for itself ten minutes after you start to use it, and pay its owner in money-saving and comfort every day

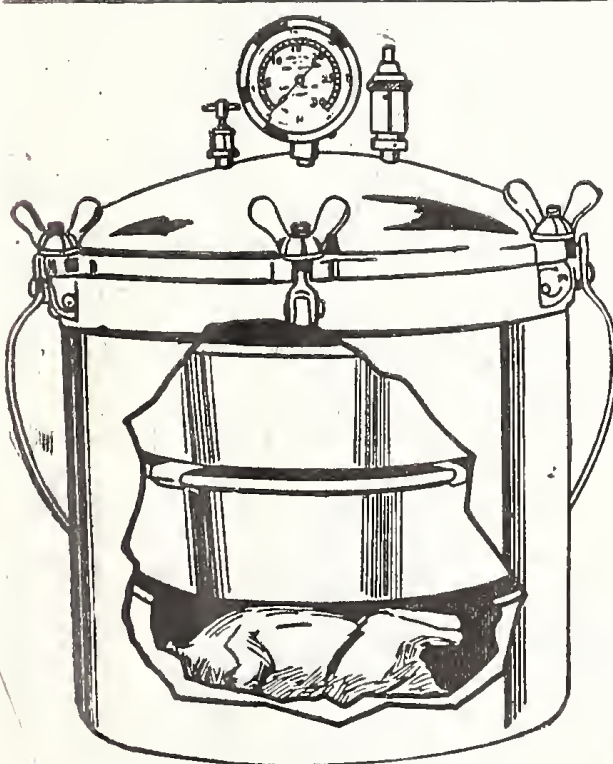

"The Entire Meal Ready to Serve in Thirty Minutes.

\section{LOWEST PRICES EVER! GREATLY REDUCED}

Don't wait any longer. Here's a price that puts the great National in ready reach of every home Let your hopes of owning a National come true with these new low prices.

10.Qt. Capacity, was $\$ 16.00$ now $\$ 14.50$ 12-Qt. Capacity, was $\$ 20.00$ now $\$ 16.50$ 18-Qt. Capacity, was $\$ 24.00$ now $\$ 18.50$ 25-Qt. Capacity, was $\$ 28.00$ now $\$ 22.00$ All prices include delivery by $P$. P. or prepaid express anywhere in the country.

They are sold subject to your approval. Send your order at once and we will make prompt shipment. Full directions included of course. Ask for booklet if you want to know more about them, but better just order one and let it talk for itself.

Pressure Cookery is taught in domestic science classes in the schools and colleges everywhere. It is the scientific and ecnomical way of cooking meats and vegetables tender, delicious, palatable and rutritious.

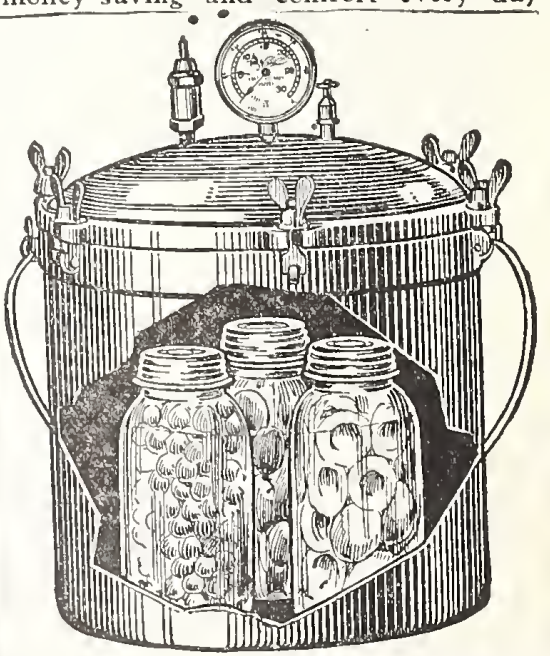

The U. S. Cold Pack Method of Canning "Safety in Canning" 


\section{Seed Potatoes}

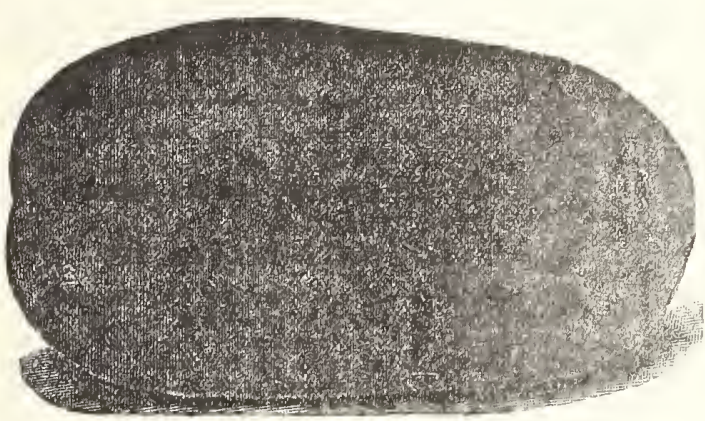

Sweet Potatoes

We have contracted for a good supply of seed sweet potatoes, and we can take care of all orders this year, providing you get them in in plenty of time. The trouble every year is with the orders that get in too late.

So if you want seed sweet potatoes, get your order in early. We can furnisl two varieties only, and only in straight bushel basket lots, that is we cannot furnish parts of a bushel, or less than a bushel of a kind.

These are measured bushels, all that will go into a bushel basket. They are not sold by weight, but are sold at so much per bushel basket. Seed Sweet Potatoes do not weigh very heavy, and they probably will not weigh out the same as a legal bushel of eating potatoes, but it will be a full bushel basketful. optatoes.

These go by express at your expense. Express is quick and safe.

Kansas or Northern Arkansas. It is not likely we will have very many of them on hand here at Shenandoah, but will ship them direct from the grower, so as to save time and freight.

We can furnish only two varieties; Yellow Jersey and Nancy Hall, and it is no use to ask us for other varieties.

Prices: Either Yellow Jersey or Nancy Hall $\$ 2.75$ per bushel basket.

These go by freight or express at your expense. Please specify whether you prefer freight or express. Express is quicker and safer.

\section{Sweet Potato Plants}

This year we will carty for you sweet potato plants in three varieties. The Nancy Hall, $v_{\text {How }}$ Jersey and Prolific, all the same price postpaid, $100 \$ 1.00$; $200, \$ 1.70 ; 300, \$ 2.35 ; 500, \$ 3.60 ; 1,000, \$ 6.00$. Larger amounts five dollars per thousand by express at your expense. Please don't order less than 100 plants, if you can not use that many get your neighbor to take part of them.

\section{California Dried Fruit}

We are getting California dried fruit in carload lots, direct from the growers in California, and selling them at a very small margin of profit to the consumers here in the corn belt. This is absolutely fresh new crop fruit of the very highest possible quality. We do not break boxes, but sell only in the original boxes as quoted.

\section{HERE ARE THE PRICES-}

PRUNES (40-50) 25 it box $\$ 3.00$

SEEDLESS RAISINS 25 it box

$\$ 3.00$

PEACHES (Semi-Peeled) 10
APRICOTS, large, 10 to box

$\$ 2.25$

These are all in large size, select fruit, and guaranteed absolutely satisfactory in every way or no trade.

The prices are not postpaid, but are for the fruit to go by express or parcel post at your expense. If you want it by parcel post, please include postage for the fruit, allowing 1 th extra for the box.

We have cars arriving every few days, and can make prompt shipments at any time.

The prunes are the large, black, extra sweet Santa Clara variety. They are soft and juicy, a very large size and very, very sweet,-so sweet, in fact, that they can be cooked if necessary without any sugar whatever.

The seedless raisins are the Thompson Seedless variety and they are the most delicious raisin grown.

The Apricots and the P.eaches are of the largest varieties grown in California and fully ripened, perfect fruit. The peaches are what is known as Semi-Peeled,-that is, they have been brushed so that most of the skin is brushed off.

Please do not ask us to break the boxes, as we could not make this low price if we did. We ship to you in the original boxes, just as they come from the grower in Califoraia.

\section{About Our Dress Goods}

First I want to tell you that all these fabrics are the latest new spring styles in materials and the lighest grade, up-todate, patterns obtainable for the rnoney. We liave gone into the matter very thor. oughly to find something that would suit as to quality, style and price.

We are offering the finest of materials, guaranteed fast color, in new coiton materials, few of which are yet in the hands of the dealers, and shown only in the best stores. It is all brand new material right from the wholesale houses and absolutely no remnants.

These materials which we offer are rayons, pongees, broadcloth, charmeuse and printed crepes, and similar novelty goods. Theý come in mäny differtent colors, in fact, every imáginable dolor. They are in beautiful designs, in prints, stripes, checks and some plaid', but they all come in pleasing figures and colors. We can give you many solt color's witl 1 no prónounced figures. You can choose according to your taste and ideas. The materials have a soft, silky finish and make up beautifully.

You are allowed your choice of color and many choose three different patterns. We sell 3 patterns, $31 / 2$ yard lengths, for $\$ 5.00$, postpaid. Or, in oversize patterns; 4 yards or more, 3 patterns for $\$ 6.00$, postpaid. You should designate whether you want regular or oversize. Also remem. ber to state the colors you desire. They come in all sorts of combinations and we can furnish about anything you misht choose.

The orders are filled right here by girls who understand dress goods and understand suiting you in colors, and they will guarantee to please you as to the colors you want. Remember, you can have all three the same color or you can have any range of colors.

Also, we furnish a spool of mercerized thread with each piece of material, which will match the dress correctly.

This dress goods carries the same positive guarantee as all the other things we sell and you are to be pleased or have your money back. I am sure when yor have seen what you get for the money there will be no question in your mind regarding the value received.

I am sure you will be more than "sur. prised when you have received this material and will be 'proud to display it to your friends and neighbors. This is just the thing to make you a beautiful new spring dress and something you can really feel dressed up in.

We hope this explains in a satisfctory manner what we have to offer you in the new spring materials, for we do not send samples of the materials.

We will be glad to have your order and give you a chance to look this material over for we know that you will be more Be sure to state when ordering whether than pleased with what we will send you. you want the regular size patterns or the oversize, as we call them. Also state color and choice of materials. You have your choice of three materials. 


\section{Lawns}

Everyone wants a nice velvety lawn. On this page are some things to interest you and to help you make the best lawn possible. Always remember when making a new lawn that all the preparation has to be done before the lawn is seed. ed; and a properly made lawn properly cared for should last a long time and improve with age.

\section{PREPARATION OF THE SEED BED}

The first step is to be sure the land is well drained. If the land does not drain naturally it must be drained by means of tiles or otherwise. The soil should be made light and porous to a depth of one foot, carefully removing all stories and rubbish found while spading. The soil should be a combination of sand, clay and humus, commonly called a rich loam.

After your lawn is started, you should give it a coating of fertilizer about every second season, as srass requires quite a lot of fertility.

Test your soil for acidity, es. pecially in shady lawns. If the soil is acid, counteract it by using lime, either crushed limestone or slacked lime, from 400 to 1000 pounds per acre, depending on the condition.

\section{SEEDING THE LAWN}

The seed bed should be firm. After the ground is well worked, either allow it to settle about one week before seeding, or, better yet, go over it with a roller to make it firm. Then broadcast the seed, rake it in, and go over it again with the roller to get ine seed in contact with the soil.

Some grasses will do fairly well under both sunny and shady conditions. For that reas. on mixture of grasses is ideal for lawns. We have studied the subject for a long time and have special mixtures of grasses made up, one for sunny places; another that we call Shady Nook Lawn Grass made up so it will grow in both sunny and shady places.

Kentucky Blue Grass is the basis of practically all lawn mixtures. These mixtures also contain some grasses that will grow quickly and make a nice lawn the first serson.

For a new lawn, use one $1 \mathrm{~b}$. of grass seed to every 200 square feet, a piece $10 \times 20$ feet. When renovating or reseeding an old lawn, one pound to every

Wholezale Net Prices, Feb. 1st. 1927, on Grass and Field Seeds

These are the prices ruling at this time, Feb. 1st but we hope to be able to continue them without cbange up te March 1st, 1927, but we will not promise positively to do so as there are indications of sharp advances in many lines. It wll be all right to order at these prices, with the understanding that there may be changes either way. Early orders are practicaliy certain of getting filled at these prices.

Time Limit. Note that these prices are good only till March 1st, 1927, and if you do not buy in that time, you should rrite for our new prices. We reserve tbe right to cancel these prices when stock on hand is sold.

These prices are f. o. b. Shenandoah, customer to pay the freight. If you want delirered prices we will make a special estimate for you on request.

Prices are stictly net, spot cash; no discount.

Safe arrival guaranteed. We guarantee that all seeds will reach you in good order.

Sold on approval. These seeds are priced and sold with the understanding that if not found strictly satisfactory they

may be returned at our expense and your money will be tofunded. You can be the judge of quality.

Free Samples. We will gladly send free samples of an kind of seed quoted bere.

\section{Your Money's Worth or Your Money Back}

It is mutually agreed and understood that any seeds of other goods ordered of us may be returned at any time within ten days after receipt if not satisfactory, and money paid for them will be refunded, but we do not, and cannot, in any was warrant the crop, as it is depending on so mus condition

beyond our control. HENRY FIELD SEED CO.

Alfalfa Per Equals

Dry land northern grown hardy 100 tb per bu Mixed Hardy (second grade) $\$ 15.00 \$ 9.00$

Common (Kans.-Nebr. Grown) 22.50 13.50

Northwestern Grown, hardy $-23.33 \quad 14.00$

Dakota No. 12, extra hardy -- 23.3314 .00

Canadian Variegated $\quad 30.00 \quad 18.00$

Grimm Certified Blackfoot _- $40.00 \quad 24.00$

Cossack, Certified super hardy $\mathbf{4 1 . 6 6}$

25.00

Clover Seed (60 ilb per bu.)

Home growin

Medium or Common Red _-.- ask for prices

Mammoth Red ............- ask for prices

Alsike - ask for prices

White Dutch Clover -..-- $50.00 \quad 30.00$

Sweet Clover (All hulled and scarified)

White Biennial -.---.--.---- 16.00

Yellow Biennial

New Grundy Co. White Bien'1 16.00

Hubam (Annual White) ...- 30.00

9.60

Timothy and Timothy Mixtures

( 45 tb per bu.)

Timothy, best home grown -- 7.50

Timothy-Alsike Mixture -.-- 14.00

Timothy-Red Clover Mixture 14.50

Timothy-Mam. Clover Mix..-- 15.00

\subsection{0}

9.60

18.00

Blue Grass

Kentucky Blue Grass _.......- 35.00

Canadian Blue Grass _....... 30.00

English Blue Grass _...-...-.- 30.00

Lawn Grass Mixture -...-.- 40.00

Shady Nook Lawn Grass --.- 40.00

Other Grasses

Red Top, fancy solid seed ---35.00

Orchard Grass - 25.00

Bromus Inermis

Bermuda Grass

Permanent Pasture Mixture -- 20.00

Permanent Meadow Mixture - 20.00

Lowland Pasture Mixture -.-- 20.00

Sudan Grass

Dwarf Essex Rape -..... 8.00

3.37

6.30

6.52
6.75

3.50

2.10

\begin{tabular}{|c|c|c|}
\hline & $\begin{array}{l}\text { Per } \\
100 \text { tb }\end{array}$ & $\begin{array}{l}\text { Equals } \\
\text { Per bu }\end{array}$ \\
\hline Sunflower Seed & $\$ 15.00$ & \\
\hline Hog Pasture Mixture & 8.00 & $\ldots$ \\
\hline Kaffir Corn \& Milo Maize -- & $\quad 3.25$ & \\
\hline Feterita & -4.00 & . \\
\hline Fodder Cane & 4.25 & \\
\hline Syrup Cane (several varieties) & 15.00 & 7.50 \\
\hline Vetch, Winter & -18.00 & \\
\hline $\begin{array}{l}\text { Canadian Field Peas } \\
\text { oy Beans ( } 60 \text { tb per bu.) }\end{array}$ & 7.00 & \\
\hline Ito San, extra early yellow & 6.00 & 3.60 \\
\hline Midwest, imp. med. yellow & -6.00 & 3.60 \\
\hline Pekin, fine for ensilage, black & 66.00 & 3.60 \\
\hline Manchu, fine main crop, yellow & $v 6.00$ & 3.60 \\
\hline Virginia, soiling, hay, brown -- & 6.00 & 3.60 \\
\hline
\end{tabular}

Inoculation for soy beans $50 \varnothing$ per bushel.

Millet (50 ib per bu.)

$\begin{array}{ll}\text { Golden } & \\ \text { Common or Fodder } \ldots \ldots \ldots & 4.75 \\ \text { Small Grain }\end{array}$

Spring Wheat, Marquis

Buckwheat -103

(W. Kherson).

Barley, bearded

Seed Corn Shelled and graded

ask for samples

2.75

2.40

1.00

1.50

Broadcast Seeders

Cyclone, each (allow postage

for $5 \mathrm{it}$ )

Pulverized Sheep Manure, cwt.

3.75 to 5.00

Seed Inoculation, (Mc Queen's).

Specify what kind of seed you want to treat, as there is a different kind of bacteria for each one.

$1 / 2$ Bushel Size $\$ .50$

1 Bushel Size -

6 Bushel Size

10 Bushel Size -_-_-_-_. 7.50 Garden Size (Combination) Inoculation for Soy Beans, Cow Peas, Vetch and all large seeded legumes, $50 \mathrm{c}$ per bu.

These are wholesale prices, good for amounts of 10 pounds of a kind or over. Add 2 cents per pound for amounts of 5 to $10 \mathrm{lbs}$. Add $5 \mathrm{c}$ per lb. for amounts below 5 lbs.

300 square feet, a piece $10 \times 30$ feet, is sufficient. On terraces or steep banks use one pound to every 100 square feet. When startirg a lawn on a bank, a nurse crop of one bushel of oats per acre can be used to help hold the soil from washing.

The new lawn need's frequent rolling to compact the soil and make the young grass roots as firm as possible; the heavier the roller the better. On old lawns, spring rolling will help overcome the loosening of the grass roots due to freezing and thawing. Prices, Mixed Lawn Grass, 50 lb., postpaid. In large lots, $40 \zeta$ lb. f. o. b. here. 